\title{
Bibliográfia
}

\section{A 2014-ben megjelent, jog- és államtudományi tárgyú könyvek annotált bibliográfiája 2. rész}

Folyóiratunkban rendszeresen jelenik meg az elmúlt időszak új, hazai szakkönyveiről készült, annotált bibliográfia. Az annotáció a könyv felhasználhatóságáról írott, rövid, tényszerü leírás, amely a bibliográfiai adatok mellett meghatározza a müfajt, illetve röviden körvonalazza a feldolgozott témát és a bemutatott eredményeket is. A mostani számban a 2014-ben megjelent könyvek második részét dolgozzuk fel. Annak megfelelően, hogy a Magyar Tudományos Művek Tára (MTMT) csak a 120 oldal terjedelmet elérő munkákat kezeli önálló kiadványként, az ettől jelentősen elmaradó kiadványokkal mi sem foglalkozunk. A bemutatás jogterületenként történik, a jogterületek elnevezésének, az egyes jogterületeken belül pedig a szerzők (szerkesztők) nevének ábécérendjében következik.

Első lépésként ezúttal is egy listát állítottunk össze különböző intézményi könyvtári katalógusok, a Magyar Országos Közös Katalógus (MOKKA), illetve az Országos Széchényi Könyvtár interneten is közölt adatai alapján. Emellett kiadók honlapján, hírlevelekben, a szerzők publikációs listáiban és saját könyvespolcainkon is kutattunk. Gyüjtőmunkánkat jelentős mértékben segítette a Debreceni Egyetem Egyetemi és Nemzeti Könyvtára (DEENK), amely köteles könyvtárként a hazai kiadványok gyűjtését, feldolgozását, illetve részben - a mienkhez képest némileg eltérő szempontok szerint - annotálását is elvégzi. 2014-től kezdve a DEENK Társadalomtudományi Könyvtár munkatársai egyéb adatbázisokat is figyelembe véve egészítik ki a listánkat, így az még pontosabb és teljesebb a korábbiaknál. Külön köszönettel tartozunk nekik érte.

A leírások elkészítése során általában a szerzők, kiadók által készített fülszövegeket, ajánlásokat, illetve a kötetekről készült recenziókat is igyekszünk fellelni és hasznosítani. Az annotációk azonban minden esetben úgy készültek, hogy magát az adott könyvet is a kezünkbe vettük, s ehhez, ha kellett, könyvtárközi kölcsönzéssel vagy más intézményekben dolgozó kollégáktól megkértük. Az annotációk tehát önálló feldolgozó munka eredményei.

Tisztában vagyunk azzal, hogy a feldolgozás szempontrendszere legjobb igyekezetünk ellenére is hiányos, illetve a sok szakterület és közremüködő okán egyenetlen. Örömmel veszünk és meg is szívlelünk ezért minden észrevételt, amely munkánkra vonatkozóan szerkesztőségünkhöz beérkezik. Szívesen fogadjuk azt is, ha a szerzők figyelmünkbe ajánlják saját könyvüket. 
A leírások első, rövidebb része tartalmazza a könyvészeti adatokat (cím, szerző/szerkesztő, a kiadó neve, a kiadás helye és éve) az arra való utalással, hogy van-e a könyvben bibliográfia (irodalomjegyzék), illetve hogy a könyv milyen müfajba sorolható be. A terjedelmet oldalszámban adjuk meg, s közöljük a kötet azonosítására szolgáló ISBN-t, illetve sorozatok esetében az ISSN-t is. A második rész röviden leírja az alkotót, illetve alkotókat. Ezt követően (a változatlan utánnyomások kivételével) általában 6-12 sor terjedelemben számba vesszük a mü tárgyköreit, föbb eredményeit. Az eredmények részletes értékelését azonban nem végezzük el. A sokszerzős, illetve a gyüjteményes munkák esetében nem kerül sor valamennyi szerző név szerinti megemlítésére, $s$ a tanulmányok számától, tematikai egymáshoz kapcsolódásától függ, hogy minden témát megnevezünk-e. A felsőoktatási tananyagok, jogszabályközlések bemutatását a lehetö legtömörebben végezzük el.

Az annotációk szerzői valamilyen formában kivétel nélkül kapcsolódnak a Debreceni Egyetem Állam- és Jogtudományi Karához, legyen szó munkatársainkról, óraadóinkról vagy jelenlegi és volt hallgatóinkról. $A z$ annotációk végén szereplő monogramok feloldása a következő: Antal Zsófia (A. Zs.) joghallgató, Bagdi Katalin (B. K.) abszolvált PhD-hallgató, Balogh Éva (B. É.) egyetemi tanársegéd, Balogh Judit (B. J.) egyetemi docens, Barta Attila (B. A.) egyetemi adjunktus, Becánics Adrienn (Be. A.) egyetemi tanársegéd, Bordás Péter (B. P.) abszolvált PhD-hallgató, Buzás Norbert (B. N.) joghallgató, Csaholczi Erika (Cs. E.) PhD-hallgató, Csonka Réka (Cs. R.) joghallgató, Deák Izabella (D. I.) közigazgatás-szervező hallgató, Fejesné Varga Zita (V. Z.) PhD-hallgató, Fekete Péter Pál (F. P. P.) joghallgató, Gábri Angéla (G. A.) PhD-hallgató, Gócza Ágnes (G. Á.) PhD-hallgató, Gyurkó Brigitta (Gy. B.) joghallgató, Halmosné Siket Zsuzsanna (S. Zs.) PhD-hallgató, Háger Tamás (H. T.) abszolvált PhD-hallgató, Horváth Henriett $(\mathrm{H}$. H.) joghallgató, Hutóczki Katalin (H. K.) joghallgató, Kecskés Lajos (K. L.) joghallgató, Kémeri Zsófia Eszter (K. Zs.) egyetemi tanársegéd, Lencse Balázs József (L. B. J.) PhD-hallgató, Lovas Dóra (L. D.) PhD-hallgató, Papp Eszter (P. E.) közigazgatás-szervező hallgató, Papp László (P. L.) egyetemi adjunktus, Papp Nikolett (P. N.) egyetemi tanársegéd, Papp Olga Katalin (P. O.) abszolvált PhD-hallgató, Pesci Marco (P. M.) joghallgató, Sütő Bianka (S. B.) PhD-hallgató, Szabó Béla (Sz. B.) egyetemi tanár, Szabó Dorella (Sz. D.) joghallgató, Szabó Zsófia (Sz. Zs.) PhD-hallgató, Szemesi Sándor (Sz. S.) egyetemi docens, Szendrői Anna (Sz. A.) PhD-hallgató, Szilágyi Dániel (Sz. D.) PhD-hallgató, Szilágyi Gábor (Sz. G.) joghallgató, Tomasovszky Edit (T. E.) abszolvált PhD-hallgató, Tóth Andrea Noémi (T. A. N.) egyetemi tanársegéd, Varga Judit (V. J.) egyetemi tanársegéd, Veszprémi Bernadett (V. B.) egyetemi adjunktus, Zsugyó Virág (Zs. V.) egyetemi tanársegéd. 


\section{ALKOTMÁNYJOG}

- Nagyító alatt az egyházügyi törvény - $A$ vallásszabadság védelmében BAER, David Wesley János Kiadó, Budapest, 2014 Monográfia. Terjedelem: 209. Bibliográfia a lábjegyzetekben. ISBN 9789639744387

- David Baer amerikai teológia- és filozófiaprofesszor, már 2012 januárjában nyílt levélben kritikával illette a lelkiismereti és vallásszabadság jogáról, valamint az egyházak, vallásfelekezetek és vallási közösségek jogállásáról szóló 2011. évi $\mathrm{CCVI}$. törvény tartalmát és elfogadásának módját. A hatálybalépést követöen is figyelemmel kísérte a törvény sorsát, hatásait, és további négy írása is született a témában - ezek a vitaindító levél szövegével együtt szerepelnek jelen, magyar és angol nyelvü kötetben. A második esszé akkor született, amikor az Országgyülés az elismert egyházak számát 14-röl 27-re növelte. A harmadik esszé az Alaptörvény negyedik módosítása után egy héttel jelent meg. A negyedik esszé az egyházügyi törvény új módosításával bevezetett kétszintes elismerési rendszert tárgyalta, kritizálta. Az utolsó esszé tükrözi a mostani helyzetet, egyben utal az Emberi Jogok Európai Bíróságának döntésére, miszerint a törvény több rendelkezése sérti az Európai Egyezmény két rendelkezését. A kötet második felében az esszék magyar fordítása olvasható. (D. I.)

- Választójogi kommentárok

Cserny Ákos (szerk.)

Wolters Kluwer, Budapest, 2014

Kommentár. Terjedelem: 466. Bibliográfia nincs. ISBN 9789632953755

- A szerkesztő egyetemi oktató. A kötet a magyar választójogi joganyag kommentárjait tartalmazza. A könyv először az országgyűlési képviselők választásáról szóló törvény magyarázatára tér ki, később pedig a helyi önkormányzati képviselők és polgármesterek választásáról szóló törvényröl, valamint az Európai Parlament tagjainak választásáról szóló törvényröl nyújt részletes értelmezést. A kötet továbbá ismerteti és kommentálja a nemzetiségi önkormányzati képviselöknek a választási rendjét, valamint kitér a választási eljárásról szóló törvény bemutatására is. A szerzők írásaikban részletesen, az anyagi jog és a joggyakorlat felhasználásával mutatják be a könyv témakörébe tartozó törvényeket, így komoly segítséget nyújtanak a választójogi szabályok megértésében és elsajátításában. (K. L.)

\section{- Egyházjog}

ERDő Péter (átdolgozta Szuromi Szabolcs Anzelm)

(Sorozat: Szent István Kézikönyvek, ISSN 1586-0302; 7.)

Ötödik, javított kiadás. Szent István Társulat, Budapest, 2014

Monográfia. Terjedelem: 894. Bibliográfia: 819-850. ISBN 9789632772561

- A kötet a szerző 1992-ben megjelent könyvének ötödik kiadása. Ezen kiadás tekintettel a megváltozott jogszabályi környezetre - kiemelt figyelmet szentel az új jogszabályok feldolgozására. Az első rész a történeti előzmények bemutatása 
mellett bevezeti az olvasót az egyházjog világába. A következő szerkezeti egységben az általános szabályokkal találkozhatunk, majd az egyház felépítését, részegyházakat és csoportjaikat, azok belső rendjét, valamint a megszentelt és az apostoli élet szabályait mutatja be „Isten népének joga” cím alatt. A negyedik és ötödik részben az egyház tanító, illetve megszentelő feladatait ismerhetjük meg, utóbbi legnagyobb részét a házasságjogi szabályok ismertetése teszi ki. A hatodik részt a büntetőjogi szabályok alkotják, ahová bekerültek a már megjelent, új részletszabályok. A kötetet az eljárásjogi normák rendszerezett bemutatása zárja. (K. L.)

- Utcák, terek szabadsága - Kézikönyv szervezőknek, tüntetőknek, rendöröknek és bámészkodóknak

HAJAs Barnabás

Századvég, Budapest, 2014

Kézikönyv. Terjedelem: 359. Bibliográfia: 329-345. ISBN 9786155164125

- A szerző egyetemi oktató. A gyülekezési jog a gyakorlatban kérdések meglehetősen széles spektrumát veti fel, melyek nem kizárólag jogi problémák képében jelentkezhetnek, hanem akár politikai, etikai, társadalmi, kulturális jellegüek is lehetnek. A könyv ezen sokszínüségre reflektálva tesz kísérletet a kérdések megválaszolására. A szerző mindenekelőtt a hatályos magyar gyülekezési jog kialakulásába enged betekintést. Ezt követően a gyülekezési jog, illetve a gyülekezés fogalmának bemutatására kerül sor, majd a törvény hatálya alá nem tartozó rendezvényeket ismerteti. A gyülekezés bejelentésével kapcsolatos rendörségi eljárások szabályainak szentelt fejezetet követően kerül sor a gyülekezési jog korlátainak részletezésére, valamint az „eszközhasználó” gyülekező ismertetésére. A kötet zárásaként a szerző összegző gondolatai és javaslatai jelennek meg. (B. N.)

- A közép-európai alkotmányok születése és identitása (1989-2012)

HALÁsz Iván

NKE, Budapest, 2014

Monográfia. Terjedelem: 237. Bibliográfia: 229-237. ISBN 9786155305641

- A szerző egyetemi oktató. A monográfia a közép-európai térség alkotmányozási folyamatait mutatja be. Az alkotmányozás önmagában nagy jelentőségủ az államok számára, rendszerint hosszú távú célokat, társadalmi és politikai üzenetet hordoz, és jellemzően rendkívül összetett folyamat. A monográfia megközelítése alapvetően alkotmánytörténeti és alkotmányjogi, de alapozásképpen kitér történeti, politológiai és terminológiai problémákra is. A közép-európai térség alkotmányos előtörténetéből és hagyományaiból kiindulva mutatja be a rendszerváltásokat, a térség 1989 és 2012 közötti alkotmányozási folyamatait, és elemzi a fontosabb alkotmánymódosításokat is. A szerző monográfiáját a modern középeurópai alkotmányok történelmi, politikai és hatalmi identitásának bemutatásával zárja le. (B. É.) 
- Államfö, parlament, kormány - Az államszervezet fejlődése a visegrádi országokban 1989 után

HALÁSZ Iván

(Sorozat: Kisebbségkutatás Könyvek, ISSN 1585-3144)

Lucidus, Budapest, 2014

Monográfia. Terjedelem: 369. Bibliográfia: 362-370. ISBN 9789639465879

- A szerző egyetemi oktató. A monográfia a négy visegrádi állam 1989 utáni alkotmányos fejlődésének államszervezeti részét veszi górcső alá. Tekintve, hogy az államszervezet önmagában egy meglehetősen szerteágazó fogalom, a kötet annak csak egy bizonyos, ám a hatalommegosztás szempontjából elengedhetetlen elemét emeli ki: az államfö, a parlament, valamint a kormány közötti kapcsolatrendszert. A szerző az államhatalmi szerveket történetiségükben mutatja be, és az írott szabályokon túlmenően a közjogi rendszer gyakorlati müködése során felmerült problémákra, azok alkotmánybírósági feloldására is figyelmet fordít. A könyv elején a közép-európai államok parlamentjeinek szerkezete és müködése kerül ismertetésre. A második fejezet mutatja be a köztársasági elnöki tisztség fejlődését a rendszerváltás utáni Közép-Európában, ezt követően pedig a kormányok jogállását a visegrádi államokban. A monográfia zárásaként a szerző a közép-európai államok állam- és kormányformájának a dilemmáit ismerteti. (B. N.)

- A mi Alapvetésünk: a Szegedi Tudományegyetem Állam- és Jogtudományi Kara alkotmányjogi tudományos diákkörének tanulmányai az Alaptörvény Alapvetéséhez Jakó Nóra-Sulyok Márton-Szakály Zsuzsa (szerk.)

(Sorozat: Lectiones luridicae, ISSN 2062-5588; 9.)

Pólay Elemér Alapítvány, Szeged, 2014

Tanulmánykötet. Terjedelem: 143. Bibliográfia: 137-142. és a lábjegyzetekben. ISBN 9786155300172

- A Szegedi Tudományegyetem Állam- és Jogtudományi Kara alkotmányjogi tudományos diákkörének keretében készült tanulmányok témájukban az Alaptörvény Alapvetés részének egyes cikkeihez igazodnak. Az Alapvetés tartalmával megegyezően 21 tanulmányt tartalmaz a kötet. Tanulmányok kapcsolódnak így például hazánk nevéröl, az állampolgárságról, a nemzeti jelképekröl, a forint mint hivatalos fizetőeszköz alkotmányos védelméröl, a házasságról és családról szóló rendelkezésekhez, valamint az értelmezési szabályokhoz. A tanulmánycímek ötletesen (a cikk jelölésére alliterálva) jelölik az érintett témát. Az elemzések négy típusba sorolhatóak, megjelennek az összefoglaló elemzések, a feldolgozott cikk egy-egy részére fókuszáló szövegek, az adott rendelkezés részletes elemzése mellett további jogalkotási kérdéseket felvető, valamint irodalmi idézetek felhasználásával készült tanulmányok. (Zs. V.)

- Mire való egy alkotmány? Nemzeti sajátosságok és európai konszenzus Károlyi Elisabeth (szerk.)

Károlyi József Alapítvány - Helikon, Budapest, 2014

Konferenciakötet. Terjedelem: 289. Bibliográfia a lábjegyzetekben.

ISBN 9789632275666 
- A kötet a Károlyi József Alapítvány által szervezett konferenciának az utókiadványa. A konferencia célja az volt, hogy tisztázza azokat a félreértéseket, amelyeket a multikulturalizmus bizonyos elemeinek, így, hogy az a nemzetektől származó politikai, társadalmi hagyományokon és komplex jogszokásokon alapul, gyakori elfelejtése okoz, és a szomszédos államok között gyakran egymás meg nem értését eredményezi. Az Európai Unióhoz való tartozás és összetartozás-tudat miatt e kérdések tisztázása fontos. A konferencia és általa a kötet az Alaptörvény körül kialakult vitákat alapul véve kíván összehasonlító elemzést adni az alkotmányok és azok preambulumainak szerepéröl és értelmezéséröl, a közös európai értékek fényében. Az elöadások szövege magyar, francia vagy német nyelven olvasható a kötetben (összefoglalóval a másik két nyelven). (B. É.)

- Összehasonlító médiajogi tanulmányok - $A$ „közös európai minimum” azonosítása felé

Koltay András-Nyakas Levente (szerk.)

(Sorozat: Médiatudományi Könyvtár, ISSN 2063-5222; 8.)

Médiatudományi Intézet, Budapest, 2014

Tanulmánykötet. Terjedelem: 184. Bibliográfia a lábjegyzetekben. ISBN 9786155302046

- A kötet elsősorban a Nemzeti Média- és Hírközlési Hatóság Médiatanácsa mellett müködő Médiatudományi Intézet munkatársainak tanulmányait tartalmazza, néhány más szerzővel kiegészülve. Az összehasonlító médiajogi kutatás célja az volt, hogy az egyes államok szabályozását komparatív módon, azaz egymásra reflektálva elemezze. A célok között szerepelt az is, hogy a munka során egyfajta „közös minimumot” nyerjenek a szerzők a tanulmányok által. A kötet a Médiatudományi Intézet honlapján elektronikusan is elérhető. (B. É.)

- Jog és kereszt

KondOROSI Ferenc

Bíbor, Miskolc, 2014

Kismonográfia. Terjedelem: 97. Bibliográfia nincs. ISBN 9789639988811

- A szerző egyetemi oktató, a könyvben a jog és vallás aktuális kérdéseivel kapcsolatos álláspontja, véleménye jelenik meg. A kötetben felvonultatja az alkotmányozási folyamat állomásait, továbbá kifejtésre kerül a történeti alkotmány védelme, illetve annak megcáfolása, hogy az Alkotmánybíróság valaha is a „láthatatlan alkotmány" alapján hozta volna a döntéseit. A szerző meglátása szerint az emberi jogok védelmének az ügye napjainkra lassuló pályára került, amit többek között a vallási öltözetek viselésének vagy a vallási jelképek elhelyezésének korlátozásának folyamatával igyekszik alátámasztani. (B. N.)

- Religio et constitutio

Kovács Péter (szerk.)

(Sorozat: A Pázmány Péter Katolikus Egyetem Jog- és Államtudományi Karának Könyvei. Doktorandusz tanulmányok, ISSN 2064-4078; 1.)

Pázmány Press, Budapest, 2014 
Tanulmánykötet. Terjedelem: 232. Bibliográfia fejezetenként. ISBN 9789633081709

- A kötet a Pázmány Péter Katolikus Egyetem Jog- és Államtudományi Kara doktorandusz hallgatói előadásainak szerkesztett változata, két szimpózium előadásait tömöríti. Első része „Az egyházakkal összefüggő kérdések a hazai és az európai joggyakorlatban" címü témakörhöz kapcsolódó elöadásokat, míg a második rész „Az Alaptörvény egy éve és hatása” címmel meghirdetett szimpóziumra készített munkákat tartalmazza. A könyvben az adott témakört változatosan, több oldalról, illetve lényeglátóan, európai kitekintéssel feldolgozó műveket olvashatunk. (K. L.)

- A konstitucionalizmus archeológiája - Történetek és elméletek az összehasonlító alkotmánytan köréböl

PAKSY Máté

(Sorozat: Recta Ratio, ISSN 2064-7107)

Gondolat, Budapest, 2014

Monográfia. Terjedelem: 303. Bibliográfia a lábjegyzetekben.

ISBN 9789636932695

- A szerző egyetemi oktató. Monográfiájában azokat a jogi-politikai diskurzusokat vizsgálja, amelyek a hatalom korlátozhatóságának kérdésére fókuszáltak. A szerző az alkotmányosság számos fontos kérdését feldolgozza, a könyvben a jogi dogmatika, a jogelmélet és a jogértelmezés bizonyos aspektusait is elemzi. A kötet három nagy szerkezeti egységre osztott. A Jogbölcseleti prelúdium címü fejezetben a szerző célja a jogpozitivizmus irányzatához tartozó szerzők álláspontjának kritikai bemutatása. A konstitucionalizmus archeológiája című fejezet az alkotmányosság eszméjének különböző kultúrákban történő megszületését mutatja be, tudományos nézőpontjából. A Törvények árulása? A jogdogmatika erkölcsi semlegessége illegitim jogrendszerben címủ részben pedig egy esettanulmány keretében vizsgálja a jogászok lehetőségeit a jogtudósi kritikára az autokratikus rendszerben. (B. É.)

- Alkotmányjog bachelor szakos hallgatók számára

Paulovics Anita (szerk.)

MEK, Miskolc, 2014

Egyetemi jegyzet. Terjedelem: 143. Bibliográfia: 143. ISBN 9786155216329

- A 2012-es első kiadás második utánnyomása. Annotációját lásd a Pro Futuro 2014/1. számában. (B. É.)

- Magyarország alkotmányjogának alapjai

Petrétel József-Tilk Péter

Kodifikátor, Pécs, 2014

Tankönyv. Terjedelem: 246. Bibliográfia: 245. ISBN 9789638991232

- A szerzők egyetemi oktatók. Magyarország Alaptörvénye, annak módosításai és a kapcsolódó sarkalatos törvények hatálybalépése szükségessé tette a magyar alkotmányjogi tananyag igazságügyi igazgatási képzésben részt vevő hallgatók részére való átdolgozását. $A$ kötet az alkotmányjoggal kapcsolatos alapvető is- 
meretek rendszerezését végzi el. Az elméleti alapokkal kezdődik, majd rátér a hatályos hazai szabályozás legfontosabb összetevőire, különösen az alapvető intézményekre és az államszervezeti szabályozás előírásaira. A kötet szükebb terjedelemben az alapvető jogokkal kapcsolatos kérdésekröl is szól. Nem törekszik teljességre, ezért nem érinti a más tantárgyak által részletesen oktatott egyes témaköröket (például az önkormányzatokat), illetve az alkotmányjog teljes áttekintése sem volt célja (így nem kerül bemutatásra például a Magyar Honvédség, a rendőrség, a nemzetbiztonsági szolgálat, valamint a különleges jogrend). (B. É.)

- Alkotmánybíráskodás - Szociológiai, politológiai és jogelméleti megközelitésekben Pokol Béla

Kairosz, Budapest, 2014

Kézikönyv. Terjedelem: 228. Bibliográfia a lábjegyzetekben. ISBN 9789636626778

- A szerző alkotmánybíró, egyetemi oktató. Célkitüzése, hogy az alkotmánybíráskodást az eddigi elemzések irányvonalától eltérően közelítse meg: az alkotmánybíráskodás szociológiai dimenzióit igyekszik feltárni. Kötetében néhány kérdéskörhöz (például diszkrimináció tilalma, általános személyiségi jog) kapcsolódóan áttekinti az Alkotmánybíróság döntéseinek a korábbi Alkotmányon nyugvó elvi alapjait, illetve az Alaptörvény értelmezéséhez kötődő alkotmánybírósági viták hátterét. $A z$ utolsó fejezetben a textualizmus alkotmányértelmezési módszerét tárgyalja, amelyet Antonin Scalia fejtett ki az amerikai Legfelső Bíróságon folytatott tevékenysége során. A szerző célja e felfogás elemzésével, hogy a magyar Alkotmánybíróság számára is vezérfonalat nyújtson az Alaptörvény értelmezése során. (F. K.)

- Kétharmados túlzáskormányzás, avagy a gólerős csatár a mély talajú pályán

SÁRKÖZY Tamás

Park, Budapest, 2014

Monográfia. Terjedelem: 415. Bibliográfia: 388-405. és a lábjegyzetekben. ISBN 9789633550786

- A szerző egyetemi tanár. A könyv a szerző Magyarország kormányzása 19782012 című munkájának folytatásaként jelent meg. Elöbbi művében a szerző 35 év kormányzásáról kívánt átfogó képet adni, jelen monográfia a 2010-2014-es Orbán-kormány ciklusát veszi vizsgálat alá. Kiindulópontja az a tény, hogy a „fülkeforradalom" mind hazai, mind nemzetközi szinten megosztotta a közvéleményt, különösen az új Alaptörvény tekintetében, mellyel kapcsolatban számos kritika fogalmazódott meg a jogállamiság veszélyeztetése, lebontása miatt. A munka egy kormányzástani elemzés, amely az Orbán-kormány szervezeti-technológiai és stílusbeli elemzéseit helyezi középpontba. Ezenfelül az Alaptörvény, a sarkalatos törvények és a jogalkotás alapvető tendenciáit és változásait vizsgálja, melyek közül kiemeli az új Ptk.-t. Végső megállapítása szerint „meg kell szabadulnunk az inga kétoldali kilengésétől", a szuperjogállamtól és a demokratikus dühtöl, a korlátozott jogállamiságtól, az államfelfogást és a kormányzást pedig középútra kell terelnünk. (P. M.) 
- A politikai diskurzusok alkotmányjogi szerkezete - A demokratikus közvélemény kialakulásának alkotmányos garanciái - európai standardok és közép-európai kihívások

Smuk Péter

(Sorozat: Médiatudományi Könyvek, ISSN 2064-5597)

MTA Bölcsészettudományi Kutatóközpont, Budapest, 2014

Monográfia. Terjedelem: 167. Bibliográfia: 155-167. és a lábjegyzetekben. ISBN 9789639627833

- A szerző egyetemi oktató, aki művében a demokratikus közvélemény kialakulásának fontossága mellett tör lándzsát. Nemcsak fogalmi körülhatárolásokat, hanem a politikai diskurzusok alkotmányjogi szerkezetét is bemutatja. Célja a demokratikus diskurzus instrumentális és etikai értékeinek alkotmányjogi intézményekre vetítése. Megfogalmazza az állam intézményvédelmi kötelezettségének elméleti alapjait, valamint áttekinti az európai standardokat, előbb a szabályozási koncepciókat, majd ezek megvalósulásait a közép-európai államok törvényeiben. A részletes elemzések a médiajog, a kampányszabályozás és a parlamenti jog területére koncentrálnak. (D. I.)

\section{- Erős állam - alkotmányos korlátok}

StumpF István

Századvég, Budapest, 2014

Monográfia. Terjedelem: 259. Bibliográfia a lábjegyzetekben és az egyes fejezetek végén. ISBN 9786155164194

- A szerző alkotmánybíró, egyetemi oktató. A monográfia egyrészről bemutatja az elmúlt két és fél évtized államszervezeti és kormányzati berendezkedését, illetve az abban megmutatkozó alkotmányos és politikai kihívásokat, feszültségeket, másrészröl az Alaptörvény által hozott változásokat is áttekinti. A szerző kiemelt figyelmet fordít a közteherviselés egyensúlytalanságának problémájára, a jó kormányzás tartalmára és feltételeire. Utóbbi elemeit a magyarországi viszonyok rendszerváltástól napjainkig terjedő időintervallumra kiterjedő elemzésével is szemlélteti. A szerző a közigazgatással kapcsolatban a közigazgatási bíráskodást, illetve a közszolgálati életpályát mutatja be. Az egész munka során a jogállamiság, a hatalommegosztás, a demokrácia és az alkotmányosság szempontrendszerei alapján végezte az elemzést. (B. É.)

- Tansegédlet az alkotmányjogi záróvizsgához

SzABó Zsolt

(Sorozat: Werbőczy-sorozat, ISSN 2062-2538)

Harmadik, átdolgozott kiadás. Patrocinium, Budapest, 2014

Tankönyv. Terjedelem: 234. Bibliográfia nincs. ISBN 9786155337772

- A szerző egyetemi oktató. A tankönyv felépítésében követi a Pázmány Péter Katolikus Egyetem Állam- és Jogtudományi Karán az alkotmányjog-záróvizsga témaköreit, tartalmazza azok vázlatát, lényeges elemeit, a témához tartozó jogszabályokat és jogforrásokat, illetve az alkotmánybírósági határozatokat. A tankönyvben az általános alapelvi, illetve történeti témák után az államszervezeti tételek, majd 
a jogforrások, az állampolgárság, a népszavazás, a választójog és helyi a önkormányzatok témakörei, végül az alapjogi témák következnek. (D. I.)

- Bevezetés az alkotmányjogba - Az Alaptörvény és Magyarország alkotmányos intézményei

Trócsányi László-Schanda Balázs (szerk.)

Harmadik, átdolgozott kiadás. HVG-ORAC, Budapest, 2014

Tankönyv. Terjedelem: 489. Bibliográfia a tanulmányok végén és a lábjegyzetekben. ISBN 9789632582535

- A szerzők a Pázmány Péter Katolikus Egyetem Jog- és Államtudományi Karának, valamint a Szegedi Tudományegyetem Állam- és Jogtudományi Karának oktatói. A könyv újabb kiadása követi az Alaptörvény és a hozzá kapcsolódó sarkalatos törvények változásait. Rendszerezi a hatályos alkotmányjogi szabályozást, és alkotmányelméleti, illetve államszervezeti kérdéseket kíván tisztázni, de emellett nem titkolt célja, hogy az olvasó ízelítőt kapjon az alkotmányjogi kultúrából is. A könyv elsőként az alkotmányos alapokra koncentrál, majd az államforma, kormányforma és az államszerkezet, az államalkotó tényezők és a jogforrási rendszer kerül bemutatásra. Ezután a közvetlen demokrácia és a választójog témakörei következnek, majd az államszervezetet alkotó alkotmányos intézményeket, végül a helyi önkormányzati rendszert, a közpénzügyeket és a különleges jogrendet mutatja be. (D. I.)

- The Refugee Law Reader - Cases, Documents and Materials

Vedsted-Hansen, Jens (ed.)

Hetedik kiadás. Hungarian Helsinki Committee, Budapest-Dublin, 2015

Kézikönyv. Terjedelem: 334. Bibliográfia nincs. ISBN 9786155215278

- A kiadványt népes, nemzetközi alkotógárda hozta létre az Egyesült Nemzetek Szövetsége és a Magyar Helsinki Bizottság támogatásával. Napjainkban, amikor a menekültválság által generált problémák megoldása aktuálisabb és égetőbb, mint eddig valaha, kiváló segítségként szolgálhat kézikönyvként, amely segít eligazodni a nemzeti és nemzetközi jog által lefektetett szabályok útvesztőjében. Hat szerkezeti egységböl áll, amelyek bevezetést nyújtanak a nemzetközi menekültjogba, a menekültek nemzetközi védelmének rendszerébe, az afrikai, amerikai, ázsiai és európai menekültvédelmi szabályokba. Több mint 1500 dokumentumot tartalmaz, közöttük a legfrissebb nemzetközi egyezményeket, bírói gyakorlatot és akadémiai kommentárokat. Angol, francia, orosz és spanyol nyelven jelent meg. (P. M.)

\section{BÜNTETŐ ELJÁRÁSJOG}

- Pusztai László emlékére

Bárd Petra-Hack Péter-Holé Katalin (szerk.)

Országos Kriminológiai Intézet, ELTE ÁJK, Budapest, 2014

Tanulmánykötet. Terjedelem: 342. Bibliográfia a lábjegyzetekben.

ISBN 9789638946843 
- A kötet Pusztai László, az Országos Kriminológiai Intézet igazgatója, az ELTE Állam- és Jogtudományi Kar docense emlékére készült, aki 2014-ben lett volna 75 éves. A szerzők Pusztai László kutató-, oktatótársai, barátai és a tudományos élet jeles képviselői, akik a saját szakterületükön, mégis Pusztai László életművéhez kapcsolódva készítették el tanulmányukat. A bünügyi tudományok valamennyi területéről készített dolgozatokat a kötet szerkesztői négy nagyobb csoportba rendezték (büntető eljárásjog és büntetés-végrehajtási jog; kriminalisztika; büntető anyagi jog; kriminológia), ezzel is tükrözve azt a négy föbb tudományterületet, amelyekben Pusztai László publikált. (T. A. N.)

- Utolsók az egyenlök között - Sérülékeny csoportok törvény elötti egyenlősége a büntető igazságszolgáltatásban

BÁRdits Anna-Novoszádek Nóra-KÁdÁR András Kristóf-SıMonovits Bori-SzEgö Dóra-Vınce Dániel

Magyar Helsinki Bizottság, Budapest, 2014

Kutatási beszámoló. Terjedelem: 130. Bibliográfia a lábjegyzetekben.

ISBN 9786155215230

- A szerzők az Eötvös Loránd Tudományegyetem oktatói és hallgatói, ketten közülük a Magyar Helsinki Bizottság tagjai. A kiadvány a Magyar Helsinki Bizottság „A romák törvény előtti egyenlősége a bírósági eljárásokban és a büntetés-végrehajtásban" címü projektje keretében készült. A szerzők bemutatják a kutatás során alkalmazott módszertant, a konferencia résztvevői által megfogalmazott észrevételek alapján véglegesített eredményeiket, valamint a fókuszcsoportos beszélgetések tapasztalatait. Ezáltal az elkészült beszámoló speciális szempontból nyújt tájékoztatást a büntető igazságszolgáltatás működéséről, kifejezetten arra a kérdésre keresve a választ, hogy az képes-e biztosítani a roma és nem roma terheltek törvény előtti egyenlőségét. (Sz. Zs.)

- A büntetés-végrehajtási törvény magyarázata

Belovics Ervin-Vókó György (szerk.)

HVG-ORAC, Budapest, 2014

Kommentár. Terjedelem: 475. Bibliográfia: 465-475. és a lábjegyzetekben. ISBN 9789632582283

- Az egyetemi oktató és egyben gyakorló jogász szerzők munkája a büntetések, az intézkedések, egyes kényszerintézkedések és a szabálysértési elzárás végrehajtásáról szóló 2013. évi CCXL. törvény gyakorlati alkalmazását segíti. A magyar büntetés-végrehajtás történetének, jogi szabályozásának bemutatását követően foglalkozik a büntetés-végrehajtási jog fogalmi meghatározásával, majd a törvény szerkezeti felépítését követve mutatja be az egyes rendelkezéseket. A törvény hatályos szövegét az egyes szakaszokhoz füzött magyarázat követi. A könyv külön érdeme, hogy mind a tudományelmélet, mind a gyakorlat köréböl megjelöli a kapcsolódó ismereteket, és utal a kapcsolódó jogszabályok tartalmára is. Szerkezetéből következően könnyen használható a jogalkalmazók, a büntetés-végrehajtás szakemberei számára, és az egyetemi oktatásban is. (V. Z.) 
- Börtönügyi lexikon

Bencze Béla

Kronosz, Pécs, 2014

Kézikönyv. Terjedelem: 272. Bibliográfia: 261-263. ISBN 9786155339899

- A szerző büntetés-végrehajtási szakember. Könyvében bemutatásra kerülnek a büntetés-végrehajtási jog alapvető fogalmai és az elítéltek egymás között használt argókifejezései. A fogalmi alapvetéseket követően helyet kap a büntetőjog, büntetés-végrehajtási jog területén ismert jogtudósok munkásságának bemutatása, valamint a szerző a szabadságvesztés büntetés letöltésére szolgáló intézmények és az elítéltek munkáltatását biztosító gazdasági társaságok ismertetésére is figyelmet fordít. A címszavak nemcsak a magyar, hanem a nemzetközi viszonylatban előforduló személyekre és kifejezésekre is kitérnek. A szerző számos képi illusztrációval és a könyv végén található kronológiai, valamint statisztikai adatokkal teszi még érdekesebbé a müvet. (S. Zs.)

- $A$ védői szerepkör értelmezésének kérdései - különös tekintettel a büntetőbíróság előtti eljárásokra

BÉRCEs Viktor László

(Sorozat: Doktori Értekezések, ISSN 2064-1907; 5)

PPKE JÁK, Budapest, 2014

Monográfia. Terjedelem: 316. Bibliográfia: 309-316. ISBN 9789633081747

- A szerző a Pázmány Péter Katolikus Egyetem oktatója, ügyvéd, kúriai főtanácsadó. E munkája a 2012-ben megvédett doktori disszertációjának átdolgozott kiadása. A mü a védői tevékenységet főként jogi, etikai és taktikai aspektusból kívánja vizsgálni. Ennek keretében foglalkozik szabályozásának történetével, alapvető dogmatikai kérdésekkel, majd a védői tevékenységgel általában, azután pedig külön is elemzi a meghatalmazott és a kirendelt védőre vonatkozó szabályokat. A szerző a további fejezetekben a büntetőeljárás folyamatát követve mutatja be a védő funkcióját és tevékenységét. A kötet erénye, hogy a jogszabályok nyelvtani értelmezése mellett megjeleníti a szerző és a jogirodalom más képviselői által megfogalmazott kritikákat, és magában foglalja a készülő új büntetőeljárási törvénnyel kapcsolatos kodifikációs javaslatokat is. (T. A. N.)

- A szabálysértési törvény magyarázata

BIsZTRICZKı László-KáNTÁs Péter

Második, átdolgozott, hatályosított kiadás. HVG-ORAC, Budapest, 2014 Tankönyv. Terjedelem: 809. Bibliográfia nincs. ISBN 9789632582375

- A szerzők gyakorlati jogászok, akik a szabálysértési jog területéről számos publikációt jegyeznek. Céljuk a szabálysértési törvény 2014. július 1-jéig hatályba lépett módosításaival egységes szerkezetbe foglalt tankönyv készítése volt, melyet e jogterület iránt érdeklődők haszonnal forgathatnak. A kötet kommentárszerüen mutatja be a szabálysértési jog egyes rendelkezéseit, pontosan követve a törvény szerkezetét. A könyv erénye emellett, hogy nemcsak a szabálysértési törvényt, hanem más, kapcsolódó jogszabályok rendelkezéseit és eseti döntéseket is feldolgoz. A mü elején található rövidítések jegyzéke a könnyebb követhetőséget biztosítja. (T. A. N.) 
- Poligráf-Müszeres vallomásellenőrzés a bünügyekben

BudAHÁZI Árpád

NKE, Budapest, 2014

Monográfia. Terjedelem: 296. Bibliográfia: 273-286. ISBN 9786155305467

- A szerző az NKE oktatója. E munkája a 2013-ban megvédett PhD-értekezésének átdolgozott kiadása. Erénye, hogy bemutatja a poligráfban és egyéb, vallomást ellenőrző müszerekben rejlö lehetőségeket, előnyöket és korlátokat is, melyeket a büntetőügyben eljáró hatóságoknak ismerniük kell. A kötet kitér annak vizsgálatára, hogy helye van-e a poligráfnak a magyar kriminalisztikában, mely módszerekkel tehető még hatékonyabbá a müködése, a vonatkozó szabályok megfelelnek-e a kapcsolódó nemzetközi követelményeknek, és elősegítik-e a büntetőeljárás hatékonyságát. Elemzi a müszeres vallomás-ellenőrzés megbízhatóságát, valamint azt is, hogy hozzájárul-e a nyomozás feladatainak teljesítéséhez, továbbá alkalmas-e arra, hogy bizonyítási eszközökhöz vezessen. A kutatási eredmények összefoglalójában a szerző külön csoportokba rendezett javaslatokat fogalmaz meg a jogelmélet, a jogalkotás és a jogalkalmazás számára. (T. A. N.)

- Börtönügyi kaleidoszkóp - Ünnepi kötet Dr. Lörincz József 70. születésnapja tiszteletére

Deák Ferenc-Pallo József (szerk.)

(Sorozat: Börtönügyi Tanulmányok, ISSN 2064-5457; 1.)

Büntetés-végrehajtás Tudományos Tanácsa, Budapest, 2014

Tanulmánykötet. Terjedelem: 249. Bibliográfia a lábjegyzetekben.

ISBN 9789638999603

- A kötet dr. Lőrincz József nyugalmazott büntetés-végrehajtási dandártábornok, egyetemi tanár 70 . születésnapja alkalmából készült. A szerzők egyetemi oktatók és büntetés-végrehajtási vezetők, szakemberek. A huszonkét tanulmány az ünnepelt tudományos kutatási területéhez kapcsolódóan a büntetés-végrehajtás gyakorlati és elméleti kérdéseibe nyújt betekintést, ennek során az egyes munkák érintik a büntetés-végrehajtás jogi oktatásának kérdéseit, a büntetés-végrehajtási bíró, valamint az ügyész szerepét, továbbá a fogvatartottak jogait az emberi jogi követelmények tükrében, és a kodifikációs lépéseket is. Bemutatja mindezeken kívül a szabadságvesztés és a kényszergyógykezelés történeti fejlödésének állomásait is. A tanulmánykötetet különösen értékessé teszi, hogy komplex képet nyújt a büntetés-végrehajtás különbözö területeiröl és azok kapcsolódási pontjairól. (V. Z.)

- Studia in Honorem Lajos Kovács 65

Deres Petronella-Homicskó Árpád Olivér (szerk.)

(Sorozat: De iuris peritorum meritis, ISSN 1789-0896; 9.)

KRE ÁJK, Budapest, 2014

Tanulmánykötet. Terjedelem: 227. Bibliográfia a tanulmányok végén és a lábjegyzetekben. ISBN 9789639808584

- A könyv szerkesztői a KRE ÁJK oktatói. Kovács Lajos a KRE ÁJK címzetes egyetemi docense, nyugalmazott rendőr ezredes; az ünnepi kötet 65 . születésnapja 
alkalmából készült. A kötetben szereplő tanulmányok szerzői között találhatunk alkotmánybírót, ügyvédet, ügyészt, egyetemi oktatót és nyugalmazott rendőrtisztet is. A kötet elején az ünnepelttel készült interjút olvashatunk, amely betekintést enged több jelentős bủntény nyomozásának folyamatába. A tanulmánykötetben elsősorban büntető anyagi jogi és kriminalisztikai kérdéseket tárgyaló müvek szerepelnek, melyek között több olyan is akad, amely rávilágít a büntető anyagi jog problematikus kérdéseire. Az interjú és a könyv végén található fényképmelléklet hozzájárul ahhoz, hogy jobban megismerjük az ünnepelt személyét és munkásságát. (S. Zs.)

- Büntetőeljárási jog II.

Dobrocsı Szilvia

(Sorozat: Werbőczy-sorozat, ISSN 2062-2538)

Negyedik, átdolgozott kiadás. Patrocinium, Budapest, 2014

Egyetemi jegyzet. Terjedelem: 115. Bibliográfia nincs. ISBN 9786155337635

- A szerző a Károli Gáspár Református Egyetem oktatója. A jegyzet kifejezetten az egyetemi szemináriumokhoz készült, és dogmatikai rendezettsége, átláthatósága folytán segítséget kíván nyújtani a hallgatóknak a későbbi vizsgák teljesítéséhez. A kötet a büntetőeljárási jog második részével, a bíróság előtti eljárásokkal foglalkozik. A jegyzet nem csupán a jogszabály és föbb bírói gyakorlat vázlatos bemutatására törekszik, hanem ítéletminta és táblázat beemelésével, továbbá ellenőrző kérdésekkel is igyekszik a hallgatók felkészülését szolgálni. (L. B. J.)

- Magyarország új büntetés-végrehajtási kódexe

Domokos Andrea (szerk.)

(Sorozat: Acta Caroliensia Conventorum Scientiarum luridico-Politicarum X., ISSN 2063-4757)

KRE ÁJK, Budapest, 2014

Konferenciakiadvány. Terjedelem: 96. Bibliográfia a lábjegyzetekben.

ISBN 9789639808577

- A Károli Gáspár Református Egyetem Állam- és Jogtudományi Kara 2014. május 5. napján konferenciát rendezett Magyarország Új Büntetés-végrehajtási Kódexe címmel. E kötet a téma neves hazai elméleti és gyakorlati szakembereinek ott elhangzott előadásait tartalmazza. Az előadók a konferencia központi témáját adó új kódexet különféle szemszögből közelítették meg, így kitértek a büntetésvégrehajtás egyes jogtörténeti vonatkozásaira, a mindennapok jogalkalmazóinak különböző feladataira, felhívták a figyelmet a nemzetközi és az uniós elvárásokra, valamint érintették a fogvatartottak sikeres reintegrációját és a vallásgyakorlást is. (L. B. J.)

- Igazság, ideál és valóság - Tanulmányok Kardos Sándor 65. születésnapja tiszteletére

Elek Balázs-Háger Tamás-Tóth Andrea Noémi (szerk.)

DE ÁJK Büntető Eljárásjogi Tanszék, Debrecen, 2014

274 Tanulmánykötet. Terjedelem: 385. Bibliográfia a lábjegyzetekben.

ISBN 9789634736745 
- A szerzők egyetemi oktatók, PhD-hallgatók és gyakorlati szakemberek. A kötet Kardos Sándor gyakorló jogász, egyetemi oktató 65. születésnapja alkalmából készült. A mú címe arra utal, hogy munkássága, hosszú évekig tartó ítélkezési gyakorlata garancia lehetett az igazságos, tisztességes eljárásra. A kötet elején leánya ismerteti az ünnepelt életrajzát, valamint szerepét a tudományos életben és az ítélkezésben. A továbbiakban a szerzők túlnyomórészt büntetőjogi és büntető eljárásjogi témakörben született értekezésekkel tisztelegnek az ünnepelt előtt. Eljárásjogi alapelvek, konkrét büntetőjogi tényállások, büntető eljárásjogi jogintézmények, az igazságon alapuló büntetöítélet ideáljának fejtegetései képezik a tanulmányok témáit. (G. A.)

- Büntetőeljárási jog I.

Hack Péter (szerk.)

(Sorozat: ELTE Jogi Kari Jegyzetek, ISSN 2060-5986; 14)

ELTE Eötvös Kiadó, Budapest, 2014

Tankönyv. Terjedelem: 262. Bibliográfia nincs. ISBN 9789633121986

- Valamennyi szerző az ELTE Állam- és Jogtudományi Kar oktatója. A könyv az alapfogalmaktól indulva mutatja be a büntető eljárásjog statikus részét, így kitér a történeti rendszerekre, az eljárás formáira és tartalmára, az alapelvekre, az alanyokra, majd a bizonyításra és a kényszerintézkedésekre. Ezt követően mutatja be a dinamikus büntetőeljárás egy részét, a nyomozástól a vádemelésig. A kötet a büntetőeljárásról szóló törvény mellett számos kapcsolódó jogszabályt, alkotmánybírósági határozatot és eseti döntést is feldolgoz. (T. A. N.)

- Emberek örzője: tanulmányok Lőrincz József tiszteletére I-II.

Hack Péter-Koósné Mohácsi Barbara (szerk.)

ELTE Eötvös Kiadó, Budapest, 2014

Tanulmánykötet. Terjedelem: 198 (I.); 149. (II.). Bibliográfia a lábjegyzetekben. ISBN 9789632845166 (I.); 9789632845234 (II.)

- A szerzők egyetemi oktatók, gyakorlati szakemberek. A két kötet Lőrincz József professzor 70. születésnapja alkalmából készült. Miután ismertetik az ünnepelt életrajzát, a hazai börtönügyi tudományos életben betöltött szerepét, a téma hazai szakértőinek a büntetőjog, büntetés-végrehajtás és büntető eljárásjog témakörében született különböző értekezéseit olvashatjuk. A tanulmányok csoportosítása azon egyetemeken történt meg, amelyeken a szerzők oktatnak, de többek között a Szemere Bertalan Magyar Rendvédelem-történeti Tudományos Társaság képviselőinek müveivel is találkozunk a kötetben. Tekintettel a professzor érdeklödési körére és munkásságára, a tanulmányok között visszatérő téma a magyar börtönrendszer, a bünismétlés megelőzése, egyes büntetőjogi szankciók alkotmányossága, illetve a fiatalkorúak helyzete az esetleges büntetés-végrehajtás során. (G. A.) 
- Büntető eljárásjog

HeRKE Csongor

(Sorozat: Dialóg Campus Szakkönyvek, ISSN 1417-7986; Jogi szakvizsga segédkönyvek, ISSN 1587-6659)

Ötödik, átdolgozott kiadás. Dialóg Campus, Budapest-Pécs, 2014

Tankönyv. Terjedelem: 388. Bibliográfia nincs. ISBN 9786155376337

- A szerző a Pécsi Tudományegyetem ÁJK oktatója, ügyvéd. A kötet elsősorban a jogi szakvizsga letételére készülök számára készült, amely a megírásakor hatályos jogszabályi szövegen túl az irányadó alkotmánybírósági határozatokat és kúriai gyakorlatot is feldolgozva kifejezetten a Közigazgatási és Igazságügyi Minisztérium által kiadott Jogi Szakvizsga Követelményekhez igazodik. A tananyag áttekinthető szerkezeti felépítésével, megértést szolgáló összefoglaló táblázataival és bőséges iratmintáival hozzájárul a jogi szakvizsga írásbeli és szóbeli részének teljesítéséhez. (L. B. J.)

- Büntető eljárásjogi alapkérdések

HeRke Csongor-HaUtZinger Zoltán

Negyedik, átdolgozott kiadás, AndAnn, Pécs, 2014

Egyetemi jegyzet. Terjedelem: 179. Bibliográfia: 177-178. ISBN 9789638922403

- A szerzők a Pécsi Tudományegyetem ÁJK, illetve a Nemzeti Közszolgálati Egyetem Rendészettudományi Kar oktatói, ügyvédek. A jegyzet kifejezetten a jogászképzésen kívüli, igazságügyi és jogi szakokleveles oktatásban részt vevők számára készült. A kötet az alapvető tételes büntető eljárásjogi rendelkezések és föbb elméleti ismeretek dogmatikailag rendezett és átlátható felvázolásával, valamint összefoglaló táblázatok és ellenőrző kérdések útján kíván segítséget nyújtani a hallgatóknak a sikeres tanuláshoz. A kiadvány - céljához mérten - csupán a joganyag szűkebb körével foglalkozik. (L. B. J.)

\section{- Új gazdasági büntetőeljárás}

HeRKe Csongor-Hengl Melinda

PTE ÁJK, Pécs, 2014

Egyetemi jegyzet. Terjedelem: 99. Bibliográfia nincs. ISBN 9789636426903

- A szerzők a Pécsi Tudományegyetem oktatói. Munkájuk a gazdasági büntetőjogi szakjogászképzés tematikájához igazodik: az elméleti ismeretek áttekintését követően a hangsúlyt a gazdasági és a gazdálkodással összefüggő büncselekmények gyakorlati vonatkozásaira helyezi. A szerzők az egyes résztémák feldolgozása körében a büntető törvénykönyv tényállásait, a büntetőeljárásról szóló törvény vonatkozó rendelkezéseit és a Kúria témához kapcsolódó eseti döntéseit együtt jelenítik meg. (T. A. N.)

- Eljárási büntetőjog - Dinamikus rész

FANTOLY Zsanett-GÁcsI Anett Erzsébet

(Sorozat: Fundamenta Fontium Juris Criminalis, A szegedi büntetőjogi iskola tankönyvei, ISSN 2064-3462) lurisperitus Bt., Szeged, 2014 
Tankönyv. Terjedelem: 311. Bibliográfia a fejezetek végén. ISBN 9786155411083

- Mindkét szerző a Szegedi Tudományegyetem Állam- és Jogtudományi Karának oktatója. Céljuk a joghallgatók számára a büntető eljárásjog dinamikus részének elsajátítását segítő tankönyv elkészítése volt, mely a büntetőeljárás vonatkozó szabályanyagát a nyomozástól a bírói határozatok végrehajtásáig dolgozza fel. Valamennyi fejezet felvezető jogesettel kezdődik, melynek megoldását az adott fejezet végén olvashatjuk. $A$ tananyag könnyebb érthetőségét nagyban segítik az áttekintő táblázatok. A fejezetek végén szereplő szakirodalom-jegyzék és a fejezetek kisbetűvel szedett részei a hallgatók további kutatásaihoz nyújtanak segítséget. $A$ könyv végén a jogesetek, valamint táblázatok és ábrák jegyzéke található. (T. A. N.)

- A kriminalisztika tendenciái: a bünügyi nyomozás múltja, jelene, jövője

FENYVESI Csaba

(Sorozat: Institutiones Juris, ISSN 1218-9375; Dialóg Campus Szakkönyvek, ISSN 1418-1274)

Dialóg Campus, Budapest-Pécs, 2014

Monográfia. Terjedelem: 304. Bibliográfia: 275-296. ISBN 9786155376382

- A szerző a PTE Állam- és Jogtudományi Karának oktatója, gyakorló ügyvéd. Kötetében elsősorban a kriminalisztika 21. századi világtendenciáit és jövőbeli lehetőségeit, kihívásait vizsgálja. A monográfia kilenc fejezetre tagolódik. A szerző a kriminalisztika kontinentális és angolszász fogalmának, a történeti előzményeknek a bemutatása után fontos krimináltechnikai és krimináltaktikai kérdéseket elemez, megvilágítva a bünügyi nyomozástan lehetséges fejlődési irányait. A mü felvázolja a kriminalisztika „piramis”-modelljét, mely a külföldi és a hazai szakirodalom széles körü tapasztalatainak birtokában új, modern megvilágításba helyezi a bünügyi nyomozás legfontosabb alapkérdéseit. A monográfia jól áttekinthető, külön erénye a kriminalisztika és a büntetőeljárás szoros kapcsolatának sokoldalú prezentálása. A mü ajánlható mind az elméleti, mind a gyakorlati szakemberek számára. (H. T.)

- Börtönügy Európában - A büntetés-végrehajtás megoldásra váró kérdései JuHÁsz Zsuzsanna

(Sorozat: Fundamenta Fontium Juris, ISSN 2061-1609; 6.)

lurisperitus Bt., Pólay Elemér Alapítvány, Szeged, 2014

Monográfia. Terjedelem: 205. Bibliográfia: 191-205. ISBN 9786155300226

- A szerző az SZTE Állam- és Jogtudományi Karának oktatója. A monográfia elején a szerző az európai börtönügy kezdeteit és a börtönügyi alapelveket mutatja be. Ezt követően a mü további fejezetei a napjainkban aktuális büntetés-végrehajtási problémákra reflektálnak, ezen belül is a szabadságvesztés büntetés végrehajtásának kérdéseire. A szerző e körben részletesen foglalkozik a büntetés-végrehajtási intézetek túlzsúfoltságával, a fogvatartottak egészségügyi ellátásával, mentális egészségükkel és a kapcsolattartás kérdésével. Ezen túlmenően a fogvatartottak speciális csoportjait (fiatalkorúakat, nőket, időseket és a külföldieket) érintő sajátos problémákat is alaposan elemzi. A mü erénye, hogy a szerző minden 
egyes fejezetben számos döntést ismertet az Emberi Jogok Európai Bíróságának esetjogából, amelyeken keresztül a gyakorlatban felmerülö konkrét problémákat is megismerhetjük, így széles rálátást biztosít nemcsak Magyarország, hanem több európai ország börtönviszonyaira is. (S. Zs.)

- Büntető eljárásjogi alapfogalmak

Kıs László-NAGY Anita-SzÉKELY György László

Miskolci Egyetemi Kiadó, Miskolc, 2014

Egyetemi jegyzet. Terjedelem: 156. Bibliográfia nincs. ISBN 9789636619336

- A 2011-es első kiadás változatlan utánnyomása. Az első kiadás annotációját lásd a Pro Futuro 2011/1. számában. (L. B. J.)

- Büntetés-végrehajtási jogi alapfogalmak LöRINCZ József-NAGY Anita Miskolci Egyetemi Kiadó, Miskolc, 2014 Egyetemi jegyzet. Terjedelem: 132. Bibliográfia nincs. ISBN 9789636619770

- A 2011-es kiadás változatlan utánnyomása. Az első kiadás annotációját lásd a Pro Futuro 2014/2. számában. (L. B. J.)

- Tendenciák és alapvetések a bünügyi tudományok köréböl Ruzsonyi Péter (szerk.)

NKE RTK, Budapest, 2014

Tanulmánykötet. Terjedelem: 391. Bibliográfia a lábjegyzetekben és a tanulmányok végén. ISBN 9786155491337

- A tanulmánykötet elsősorban a Nemzeti Közszolgálati Egyetem Rendészettudományi Doktori Iskolájának doktorandusz hallgatói számára gyüjt össze a Nemzeti Közszolgálati Egyetem oktatói által jegyzett, bűnügyi tudományok területén született dolgozatokat. Az egyes tanulmányok egységes belső struktúrát követnek, mely szerint valamennyi bemutatja az adott téma történeti megközelítését, továbbá nemzetközi kitekintést tesz, és képet ad az új fejlödési irányokról, valamint a továbblépés lehetőségeiről is. A kötet tudományos igénnyel kimunkált szakkönyv, amely a szerzők szükebb területének alapvetéseit és fejlődési tendenciáit foglalja össze. (T. A. N.)

- Kézírásvizsgálat - Kandidátusi disszertáció a kriminalisztika köréből (1959) VARGHA László

PTE ÁJK, Pécs, 2013

Monográfia. Terjedelem: 189. Bibliográfia a lábjegyzetekben és a fejezetek végén. ISBN 9789636425685

- Vargha László egyetemi tanár elsőként szerzett tudományos fokozatot kriminalisztikából, s megteremtette a kriminalisztikai oktatás alapjait. E monográfia Vargha László születésének 100 éves évfordulója kapcsán, az 1959-ben elkészített „Kézírásvizsgálat” című kandidátusi értekezésének utólagos megjelentetése a pécsi jogi kar oktatóinak gondozásában. A kötet a technikai és természettudományos írásvizsgálati módszerek összefoglaló ismertetését nyújtja, különös te- 
kintettel a sérült okiratok rekonstrukciójára, a láthatatlan írások láthatóvá tételére, a kézírás korának meghatározására. Vizsgálja az íráshamisításokkal szemben alkalmazható tudományos módszereket is. A monográfiát különösen értékessé teszik az egyes módszerek alkalmazásával kapcsolatos szemléltető fényképfelvételek. Ez a kötet kimaradt a 2013-ban megjelent müvek bibliográfiájából. (V. Z.)

\section{BÜNTETŐJOG}

- Kommentár a büntető törvénykönyvröl szóló 2012. évi C. törvényhez Balogh Ágnes-HornYÁK Szabolcs-MaKal Lajos Menedzser Praxis, Budapest, 2014 Kommentár. Terjedelem: 948. Bibliográfia: 946-947. ISBN 9789638998613

- A kommentárirodalom a büntetőjog fejlesztésének egyik legfontosabb eszköze. Ennek egyik újabb darabja a Pécsi Tudományegyetem oktatói, valamint a Pécsi Ítélőtábla elnöke által jegyzett, 2014-ben megjelent kommentár. Szerkezete, felépítése világos, jól tagolt, követi a Btk. szerkezetét, általános és különös részre oszlik. Az elméleti bevezetés és a magyarázat után a vonatkozó bírói gyakorlatot is ismerteti, az egyes bírói határozatokból a releváns részek négy-öt sorban öszszefoglalva kerülnek bemutatásra. A különös részben az egyes tényállások bemutatása, majd elemzése után, ha szükséges, a vonatkozó nemzetközi jogi és uniós szabályokat is ismerteti. (A. Zs.)

- Büntetőjog II. - Különös rész a 2012. évi C. törvény alapján

Belovics Ervin-Molnár Gábor Miklós-SINKu Pál

Harmadik, hatályosított kiadás. HVG-ORAC, Budapest, 2014

Tankönyv. Terjedelem: 920. Bibliográfia nincs. ISBN 9789632582542

- A szerzők gyakorlati szakemberek és egyetemi oktatók. A könyv az egyes büncselekmények dogmatikai elemzésén és gyakorlatán túl a hatályos szabályozás történeti előzményeit, a rendelkezések alkotmányos alapjait, a kapcsolódó joggyakorlat meghatározó döntéseit is bemutatja, és tartalmazza a témához kapcsolódó jelentősebb jogirodalmat is. A hatályosított kiadás átvezeti a Btk. és a kerettényállásokat kitöltő más jogszabályok módosításait, bemutatja a kódexbe bekerült új tényállásokat és az ítélkezési gyakorlat legújabb fejleményeit, valamint a változó joggyakorlatot is. Szakvizsgázók és gyakorló jogászok számára is jól használható. (G. Á.)

- Korrupciós büncselekmények a büntető igazságszolgáltatás tükrében INZELt Éva-Kerezsı Klára-LÉvaY Miklós

ELTE ÁJK, Budapest, 2014

Kutatási beszámoló. Terjedelem: 156. Bibliográfia a lábjegyzetekben. ISBN 9789632845579

- Az ELTE ÁJK által elvégzett és ismertetett kutatás a korrupciós bűncselekményeket vizsgálja. A kötet elején a kutatók a kutatás céljait, annak hipotéziseit, módszereit, majd az eredményeket mutatják be részletesen. Az alapvető fogal- 
mak tisztázása után az eredmények bemutatása logikus, jól követhető. A kutatás egyes állomásai, valamint az interjúk és a nyomozási tapasztalatok is helyt kapnak a könyvben. A mü második részében a korrupciós büncselekmények okai, illetve a megelőzésre vonatkozó lehetőségek kerülnek bemutatásra, végül pedig a következtetések és a megoldási javaslatok következnek. Összességében egy a választott témát átfogóan, kriminalisztikai, kriminológiai és anyagi jogi szempontból egyaránt vizsgáló kutatás eredményeit ismerheti meg az olvasó. (A. Zs.)

- Anyagi büntetőjog - Általános rész I-II.

NAGY Ferenc

lurisperitus Bt., Szeged, 2014

Tankönyv. Terjedelem: 302. (I.); 304. (II.). Bibliográfia a fejezetek végén.

ISBN 9786155411090 (I.); 9786156411106 (II.)

- A szerző a Szegedi Tudományegyetem professzora, aki több évtizedes hagyományt folytatva adja közre a Büntetöjog Általános részének tankönyvét, két kötetben. A felsőoktatási reformfolyamatok és az oktatási módszerek változásai hatására döntöttek úgy a szegedi egyetem oktatói, hogy egy új tankönyvsorozattal kívánnak megfelelni a folyamatosan változó igényeknek. Ebbe a sorozatba illeszkedik megújult arculattal a kétkötetes Általános rész is, amely Tokaji Géza kézikönyvének, valamint a szerző által korábban írt büntető anyagi jogi tankönyveknek a méltó utódja. A könyv a 2012. C. törvény általános részébe vezeti be az olvasót. Elsősorban joghallgatóknak készült, de hasznos olvasmány a gyakorló jogászok számára is. (G. Á.)

\section{- Új Btk. kommentár - Frissités az első kiadáshoz}

Polt Péter (főszerk.)

Nemzeti Közszolgálati és Tankönyvkiadó, Budapest, 2014

Kommentár. Terjedelem: 379. Bibliográfia a fejezetek végén. ISBN 9786155344565

- 2013-ban jelentette meg a Nemzeti Közszolgálati és Tankönyv Kiadó a 2013. július 1-jén hatályba lépett új Btk. kommentárját nyolc kötetben. Jelen kommentár ezen nyolc kötetet egészíti ki, feloldva a gyakorlat oldaláról jelzett hiányosságokat. A kötet 38 fejezetböl áll, és tagolása - a megszokottól eltérően - nem a Btk. szerkezetét követi. Az egyes fejezetek különböző szerzőktöl származnak, a fogalmak és tényállások bemutatása, az ahhoz füződő magyarázatok, a vonatkozó bírói gyakorlat, az esetleges kúriai állásfoglalások és $A B$ döntések, az

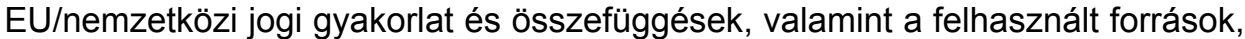
a szakirodalom adatai minden fejezetben megtalálhatók. A mú azáltal, hogy az egyes fejezetekben egy-egy elismert szakember állásfoglalását jeleníti meg, az általános kommentároknál részletesebb elemzést nyújt. (A. Zs.)

- A csalás

MAdal Sándor

Opten, Budapest, 2014

Kézikönyv. Terjedelem: 187. Bibliográfia nincs. ISBN 9786155122132

- A szerző a Debreceni Egyetem Állam- és Jogtudományi Karának oktatója. A kötet 
gyakorlati ismereteket nyújt a csalás - szövegezésében hosszú ideje változatlan, ám gyakorlatában folyamatosan változó - tényállásához. A szerző a csalás alaptényállását mutatja be bírósági döntéseken keresztül, öt fejezetben elemezve a csalás elkövetési magatartását, a kárt, a bűnösség kérdését, illetve a minősített esetek vonatkozásában fellelhető bírósági döntéseket. Az egyes tényállási elemek ismertetése a gyakorlat szemszögéből történik, a döntéseken keresztül megismerhetőek a csalás tényállásához kapcsolódó elvi jelentőségü tételek, és az egyes bírói fórumok által elfoglalt elvi jelentőségü álláspontok is. (G. Á.)

\section{EURÓPA-JOG ÉS NEMZETKÖZI JOG}

- Tíz év az Európai Unióban: felzárkózás vagy lecsúszás?

ÁGH Attila-VÉRTEs András-FLEck Zoltán

Kossuth, Budapest, 2014

Kézikönyv. Terjedelem: 232. Bibliográfia: 232. és a fejezetek végén.

ISBN 9789630980104

- A könyv átfogó képet kíván nyújtani Magyarország sorsáról az Európai Unióban. A csatlakozást követő évek társadalmi-politikai vonatkozásait Ágh Attila, jogi dimenzióit Fleck Zoltán, gazdasági pályaívét Vértes András mutatja be. A kötet első része az EU jövőjét és a magyar felzárkózás esélyeit taglalja, külön kitérve hazánk 2010-ben kezdődött „szabadságharcára”. A gazdasági növekedésről szóló fejezet utal az eltelt, felzárkózás nélküli tíz évre, kitérve a jóléti rendszerváltásra, az államháztartási kiigazításokra, a pénzügyi világválság hatásaira és kezelési kísérleteire. Bemutatja a kormányzat helyesnek vélt, illetve vitatható gazdasági döntéseit. Elöbbiek között említi az online pénztárgépek bevezetését, a közmunka kiterjesztését, a gyed extra bevezetését, míg utóbbiak között a szociális kiadások befagyasztását, a végtörlesztést, a közoktatás és köznevelés átalakítását. A kötet utolsó része a taggá válás folyamatát, a tagsággal járó jogi változások természetét, az alapjogok helyzetét és a 2010 óta lezajlott közjogi változásokat tekinti át. (Be. A.)

\section{- A nemzetközi jog hatása a magyar joggyakorlatra}

BLUTMAN László-CsatLós Erzsébet-SCHIFFNER Imola

HVG-ORAC, Budapest, 2014

Monográfia. Terjedelem: 532. Bibliográfia: 521-531. és a lábjegyzetekben. ISBN 9789632582146

- A szerzők a Szegedi Tudományegyetem oktatói, a kiadvány a tanszék egyik kutatási projektjének összegző lezárása. A kutatás célja annak vizsgálata volt, hogy a nemzetközi jog mennyiben jelenik meg a magyar (elsősorban bírósági) gyakorlatban. Megkísérel választ adni olyan kérdésekre is, mint hogy mérhető-e a nemzetközi jogon alapuló érvek súlya az egyes döntésekben, és erre miképpen utalhatnak a vizsgált határozatokban szereplő nyelvi kifejezések. A kiadvány a szegedi nemzetközi jogi iskolához hűen jogpozitivista megközelítést alkalmaz, következtetéseit javarészt a rendelkezésre álló jogi szövegek elemzéséből, fel- 
dolgozásából, illetőleg statisztikai értékeléséböl vonja le. Magas szintű módszertani megalapozást tartalmazó, teljességre törekvő, hiánypótló jellegü munka. $(H$. H.)

- An Introduction to European Integration Studies: A Study Material

Bóka János

SZTE ÁJK, Szeged, 2014

Tankönyv. Terjedelem: 148. Bibliográfia: 4. ISBN 9789633062517

- A szerző a Nemzeti Közszolgálati Egyetem oktatója. Az angol nyelvü kötet kifejezett célja, hogy az európai integrációval foglalkozó magyar és idegen nyelvű egyetemi kurzusok oktatási segédanyagaként szolgáljon. Több oldalról járja körül az európai integráció kiterjedt témakörét, kitérve egyebek mellett az Európai Unió történeti fejlődésére, döntéshozatali folyamataira, szakpolitikáira és jogára. A kötet erénye, hogy több, tankönyvek által gyakran elkerült témakörrel - így az integráció és a közösségi politika általános modelljeinek bemutatásával, az Unióval kapcsolatos társadalmi attitüdökkel, valamint az európai integráció jövőjével - is foglalkozik, mindezt pedig egy egyszerủen olvasható és a hallgatói aktivitást is elősegítő formában, számos vitaindító írás és esettanulmány szerepeltetésével teszi, különös figyelmet fordítva a kulcsfontosságú pontok, konklúziók kiemelésére és a kérdésfeltevésre. (Sz. D.)

\section{- A jog érvényesülésének térsége az Európai Unióban} Gombos Katalin CompLex, Budapest, 2014 Monográfia. Terjedelem: 216. Bibliográfia: 193-216. és a lábjegyzetekben. ISBN 9789632954172

- A szerző kúriai bíró, egyetemi oktató. Kutatási területe a bírói jogvédelem az Európai Unióban, az európai bíráskodás és az igazságügyi együttmüködés. A szerző ismerteti az uniós jog sajátosságait, a többnyelvü uniós jog természetét, és az ebből adódó problémákat, bemutatja a polgári és kereskedelmi ügyekben folytatott igazságügyi együttmüködés jelenlegi helyzetét, a harmonizációs szabályokat, az ehhez kapcsolódó igazságügyi együttmüködést a tagállamok bíróságai és az Európai Unió Bírósága között. Külön fejezetet szentel azon jogi eszközök bemutatásának, melyekkel a jogvédelem effektíve érvényesíthető mind uniós, mind tagállami szinten, illetve kitér a jog érvényesülésére az alapjogok szempontjából is. (Be. A.)

- Legális bevándorlás az Európai Unióba, különös tekintettel a családi élet tiszteletben tartásának jogára

GYENEY Laura

(Sorozat: A Pázmány Péter Katolikus Egyetem Jog- és Államtudományi Karának Könyvei. Doktori értekezések, ISSN 2064-1907; 6.)

Pázmány Press-PPKE JÁK, Budapest, 2014

Monográfia. Terjedelem: 546. Bibliográfia: 509-527. ISBN 9789633081754

- A szerző a Pázmány Péter Katolikus Egyetem oktatója, a mủ a 2011-ben megvédett PhD-értekezésének publikált változata. A migráció a 2010-es évek közepén 
egyike az Európai Unió legaktuálisabb kérdéseinek, melyben a tagállamok eltérő megközelítései miatt szinte lehetetlen egységes uniós politikát alkotni. A mü a migráció kérdésének három aspektusát vizsgálja: az uniós polgárok harmadik országbeli családtagjainak helyzetét, a társulási és együttmüködési megállapodások migrációs tárgyú rendelkezéseit, valamint a harmadik országbeli polgárok családegyesítésének szabályozását. Bemutatja a vonatkozó uniós rendelkezések fejlődéstörténetét, az Európai Unió Bíróságának kapcsolódó esetjogát, és elemzi a hatályban levő legfontosabb másodlagos jogforrásokat. Megkérdőjelezhetetlen aktualitással bíró, aktuálpolitikai szempontoktól mentes monográfia. (H. H.)

- Az EU mint a szabadság, a biztonság és a jog térsége - Magyarország az Európai Unióban, 2004-2014

Hollán Miklós (szerk.)

NKE Nemzetközi Intézet, Budapest, 2014

Tankönyv. Terjedelem: 227. Bibliográfia a fejezetek végén és a lábjegyzetekben. ISBN 9786155491399

- A szerkesztő az MTA TK Jogtudományi Intézetének tudományos főmunkatársa, egyetemi oktató. A kötetben található tanulmányok témája az Európai Unió büntetőjoggal összefüggő tevékenysége. A szerzők részletesen bemutatják Magyarország európai uniós tagságának aspektusából a büntető eljárásjog harmonizációját, az Eurojust és az Europol működését. Újszerünek és egyben rendkívül hasznosnak tekinthető a tanulmányok szerkezeti felépítése: a fejezetek egy vagy több „problémafelvető” jogesettel indulnak, amelyekkel kapcsolatosan az érdemi részben találunk megoldási javaslatokat. (K. Zs.)

\section{- Nemzetközi jog}

Kende Tamás-Nagy Boldizsár-Sonnevend Pál-Valki László (szerk.)

CompLex Wolters Kluwer, Budapest, 2014

Egyetemi tankönyv. Terjedelem: 885. Bibliográfia: 881-885. ISBN 9789632953823

- Amíg a rendszerváltás előtti időszakban kizárólag egy, állami jóváhagyással készülő tankönyv létezett a nemzetközi jog oktatására, addig napjainkban már a kínálat lényegesen sokszínübb, egyaránt találkozhatunk fordítással, illetőleg egyés többszerzős tankönyvekkel is a piacon. Az ELTE ÁJK Nemzetközi Jogi Tanszékének második tankönyve (a politológus hallgatók számára készült, néhány évvel ezelőtt megjelent mellett) a korábbi, Malcolm N. Shaw tankönyvének fordításán alapuló tananyagot váltotta fel, melynek módszertana sokszor idegen volt a magyar joghallgatók számára. A könyv célja szerint is egyetemi tankönyv, a tudományos hivatkozásokat mellőzi, ám az érdeklődő olvasó számára jelentős menynyiségü kapcsolódó szakirodalmat és jogesetet, valamint név- és tárgymutatót tartalmaz. Stílusa olvasmányos, a hazai jogi oktatás módszertanához illeszkedő, azonban terjedelme a vizsgára készülő hallgatók számára még annak tükrében is jelentős, hogy a nemzetközi jog valamennyi fontosabb területét átfogja. (Sz. S.) 
- Az Európai Unió bővitésének jogi aspektusai

KeRTÉszné Váradi Szilvia

CompLex Wolters Kluwer, Budapest, 2014

Monográfia. Terjedelem: 308. Bibliográfia: 269-308. és a lábjegyzetekben. ISBN 9789632953724

- A Szegedi Tudományegyetem adjunktusának 2013-ban megvédett PhD-értekezésén alapuló monográfia, mely az uniós jog és a nemzetközi jog határán elhelyezkedő kérdést, az Európai Unió bővítésének jogi vonatkozásait vizsgálja. Áttekinti az Európai Unió eddigi kibővítéseit, egyaránt vizsgálva a kibővítéseket és az azok idején hatályban levő jogi szabályozást is. Kitér a szakirodalomban kevéssé vizsgált kérdésekre is, mint a német újraegyesítés vizsgálata az akkori Európai Közösségek bővítése szemszögéböl. Bemutatja a kézirat lezárásakor (2014. január) folyamatban levő csatlakozási tárgyalásokat, melyek nyomán időközben Horvátország az Európai Unió teljes jogú tagjává vált. $(H . H$.)

- Nyelvpolitika és nyelvi sokszínüség az Európai Unióban

LÁncos Petra Lea

(Sorozat: A Pázmány Péter Katolikus Egyetem Jog- és Államtudományi Karának Könyvei. Doktori értekezések, ISSN 2064-1907; 7.)

Pázmány Press - PPKE JÁK, Budapest, 2014

Monográfia. Terjedelem: 295. Bibliográfia: 263-293. és a lábjegyzetekben. ISBN 9789633081761

- A szerző a Pázmány Péter Katolikus Egyetem oktatója, egyben az Európai Unió hivatalos tolmácsa. A mủ a 2013-ban megvédett doktori értekezésének publikált változata, melyet 2015-ben Herczegh Géza-emlékéremmel jutalmaztak. Elsősorban nem azt vizsgálja, hogy miként hat a nyelvi sokszínűség az Európai Unió müködésére, hanem inkább azt, hogy miként hat az uniós szabályozás és politika a nyelvi sokszínüségre. Kísérletet tesz a nyelvi sokszínüség alapvető fogalmainak definiálására, felhasználva más társadalomtudományi területek eredményeit is. Részletesen bemutatja, hogy milyen hatással volt a Lisszaboni Szerződés a nyelvi sokszínüségre. Egyedi megközelítést tartalmazó, egy rendkívül aktuális problémát többféle aspektusból megközelítő alapmüröl van szó. (H. H.)

- A magyar bírósági gyakorlat az előzetes döntéshozatali eljárások kezdeményezésének tükrében 2004-2014

Osztovits András (szerk.)

(Sorozat: Bibliotheca Curiae, ISSN 2064-9525; 2.)

HVG-ORAC, Budapest, 2014

Tanulmánykötet. Terjedelem: 235. Bibliográfia a lábjegyzetekben.

ISBN 9789632582382

- A kötet a Kúria joggyakorlat-elemző csoportjának kutatási eredményeit mutatja be, és az uniós jog magyar jogban történő alkalmazása szempontjából fogalmaz meg észrevételeket. Az öt fejezetben egyetemi oktatók és bírák (a joggyakorlatelemző csoport tagjai) segítségével részben a magyar bíróságok által 2004 óta kezdeményezett előzetes döntéshozatali eljárásokat, azok tárgyát és kimenetelét 
vizsgálja, részben pedig azokat az ügyeket mutatja be, melyekben a felek indítványa ellenére nem került sor előzetes döntéshozatali eljárás lefolytatására. (K. Zs.)

\section{- Az európai uniós jog etikai vonatkozásai}

PÜNKÖsty András

(Sorozat: A Pázmány Péter Katolikus Egyetem Jog- és Államtudományi Karának Könyvei. Doktori értekezések, ISSN 2064-1907; 9.)

Pázmány Press - PPKE JÁK, Budapest, 2014

Monográfia. Terjedelem: 227. Bibliográfia: 199-227. és a lábjegyzetekben.

ISBN 9789633081969

- A szerző a Pázmány Péter Katolikus Egyetem oktatója, a mü a 2013-ban megvédett $\mathrm{PhD}$-értekezésének publikált változata. A mủ célja annak vizsgálata, hogy az Európai Unió jogában mennyiben érhető tetten az értékeken alapuló, etikai jellegű megközelítés, és az Európai Unió joga mennyiben van összhangban a katolikus egyház tanításaival. Kiindulópontja szerint az Európai Unió nagyobb legitimitása érdekében szükség van arra, hogy egy igazságosabb intézményi ethoszt képviseljen, mellyel az Unió polgárai jobban tudnak azonosulni, és ezt igyekszik előmozdítani a Lisszaboni Szerződés azon rendelkezése is, mely az uniós értékeket tartalmazza. Egyaránt igyekszik EU-jogi és egyházi-egyházjogi megközelítést alkalmazni, váltakozó sikerrel. A mű elsősorban egyházi megközelítésből bírhat értékkel. (Sz. S.)

- 10 éve az Európai Unióban - Az előzetes döntéshozatali eljárás magyar tapasztalatai

SIMONNÉ Gombos Katalin

(Sorozat: Bírói Gyakorlat Füzetek, ISSN 2063-725X)

Opten, Budapest, 2014

Kézikönyv. Terjedelem: 196. Bibliográfia nincs. ISBN 9786155122026

- A szerző kúriai bíró, egyetemi oktató. A kézikönyv az Opten Kiadó által indított sorozat egyik különszáma, melynek célja egy adott jogterületen született döntések összefoglalása, valamint az ahhoz kapcsolódó anyagok feldolgozása. A mü a 2004-es uniós csatlakozás óta született előzetes döntéshozatali kérelmekkel kapcsolatos tapasztalatokat tárgyalja három fejezetben. Az első rész az előzetes döntéshozatalra vonatkozó általános szabályokat ismerteti, a második és harmadik fejezet pedig az ezzel kapcsolatos magyar joggyakorlatot mutatja be - utóbbi az előzetes döntéshozatalt elutasító magyar bírósági határozatokat is számba veszi. Különösen utóbbit érdemes összevetni az ugyancsak ebben a számban annotált, Osztovits András által szerkesztett, a Kúria joggyakorlat-elemző csoportja által készített könyvvel. (K. Zs.)

\section{- Az Európai Unió jogi fundamentumai}

Szabó Marcel-Láncos Petra Lea-Gyeney Laura (szerk.)

Negyedik, javított kiadás. Szent István Társulat, Budapest, 2014

Tankönyv. Terjedelem: 334. Bibliográfia a lábjegyzetekben. ISBN 9789632775203

- A szerzők a Pázmány Péter Katolikus Egyetem oktatói. A mű klasszikus uniós jogi 
tankönyv, mely többek között a jogi szakvizsgára történö felkészülést is szolgálja. 2012-ben megjelent korábbi kiadását a Pro Futuro 2014/2. számában annotáltuk. (H. H.)

- Introduction to the Law of International Organizations

SzALAI Anikó

SZTE ÁJK, Szeged, 2014

Egyetemi jegyzet. Terjedelem: 119. Bibliográfia: 116-119. ISBN 9789633062661

- A Szegedi Tudományegyetem adjunktusa által készített angol nyelvű jegyzet a nemzetközi jog egy szükebb területét, a kormányközi nemzetközi szervezetek kialakulásának történetét, müködésük jogi kereteit, valamint egyes nemzetközi szervezetek felépítésének föbb sajátosságait mutatja be. A nemzetközi szervezetek általános jellemzését követően a legnagyobb hangsúlyt az ENSZ felépítésének szenteli, de röviden bemutat számos további nemzetközi szervezetet és nemzetközi szervezetnek nem minősülö együttmüködési formát is. Oktatási célokra kiválóan alkalmas. (Sz. S.)

- A személyek jogállása az uniós jogrendben

SZALAYNÉ SÁNDOR Erzsébet

NKE, Budapest, 2014

Monográfia. Terjedelem: 231. Bibliográfia a lábjegyzetekben. ISBN 9786155305573

- A szerző egyetemi oktató, a nemzetiségek jogainak védelmét ellátó helyettes ombudsman. Könyve közel tíz év kutatómunkájának részeredménye, melyben a címmel ellentétben nem kizárólag az egyének jogi helyzetét mutatja be az Európai Unióban, hanem kitér az uniós alapjogvédelem és a strasbourgi bíróság kölcsönhatásaira - eljárási szempontból is, ideértve az Európai Unió csatlakozásának lehetőségét az Emberi Jogok Európai Egyezményéhez. Az eljárási kérdések mellett külön fejezetet szentel olyan, napjainkban különösen aktuális kérdéseknek, mint a bevándorlási politika és a nyelvhasználat kérdése az Európai Unióban. A mü erénye, hogy kitér az uniós és strasbourgi együttmüködés jövőben potenciálisan felmerülő föbb kérdéseire és problémáira is. (P. N.)

- A kisebbségi területi autonómia elmélete és gyakorlata - Nemzetközi jogi és öszszehasonlító jogi analízis

Tо́тH Norbert

(Sorozat: Nemzetpolitikai Könyvek, ISSN 2063-7322)

L'Harmattan, Budapest, 2014

Monográfia. Terjedelem: 176. Bibliográfia: 163-176. és a lábjegyzetekben. ISBN 9789632368689

- A szerző a Nemzetpolitikai Kutatóintézet munkatársa, egyetemi oktató. A könyv a területi autonómia kérdéskörét mutatja be, alapvetöen a nemzetközi jog és az összehasonlító jog nézőpontjából. Külön ismerteti a kisebbségek jogainak kötelező és soft law jellegü dokumentumokban történő biztosítását, univerzális és regionális szinten egyaránt, valamint sorra veszi a nemzetközi kapcsolatokban létező autonóm területek jogállását. Ezen belül is hangsúlyt fektet azon kérdé- 
sek megválaszolására, hogy milyen külügyi jogosítványokkal rendelkezhetnek az autonóm területek, rendelkezhetnek-e nemzetközi jogalanyisággal, nemzetközi cselekvőképességgel, illetve nemzetközi jogi felelősséggel. Hasznos ismereteket tartalmaz mindazok számára, akik érdeklődnek a kisebbségek jogi helyzete iránt, és választ szeretnének kapni arra, hogy milyen nemzetközi jogi jogcímek segítségével érhető el az autonómia és milyen nemzetközi jogi keretek között kell azt müködtetni. (Be. A.)

\section{- Az Európai Unió versenyjoga}

То́тн Tihamér

CompLex Wolters Kluwer, Budapest, 2014

Monográfia. Terjedelem: 709. Bibliográfia: 681-687. és a lábjegyzetekben. ISBN 9789632953700

- A szerző versenyjogász, egyetemi oktató. A mű a 2007-ben hasonló címmel megjelent könyv átdolgozása. Jelentősége nemcsak azért nagy, mert a magyar versenytörvény számos vonatkozásban követi az uniós szabályozást, hanem azért is, mert a magyar vállalkozások számára elengedhetetlen az uniós szabályozás ismerete és követése. Bemutatja a versenyre és annak szabályozására vonatkozó főbb elméleti modelleket, valamint a nemzeti, integrációs és globális versenyjog előnyeit és hátrányait. Részletesen foglalkozik az EU versenyjogának általános és különös részével (intézményrendszer, az uniós versenyjog sajátosságai, illetve egyes versenyjogi jogintézmények). A fejezetek végén levő összefoglalás összegzi az uniós szabályozás lényegét. (H. H.)

- Challenges of Domestic Prosecution of War Crimes with Special Attention to Criminal Justice Guarantees

\section{VARGA Réka}

(Sorozat: A Pázmány Péter Katolikus Egyetem Jog- és Államtudományi Karának Könyvei, ISSN 2064-1907; 4.)

Pázmány Press, Budapest, 2014

Monográfia. Terjedelem: 284. Bibliográfia: 259-284. és a lábjegyzetekben.

ISBN 9789633081730

- A szerző egyetemi oktató, a Magyar Vöröskereszt nemzetközi jogi szakértője, a Külgazdasági és Külügyminisztérium Nemzetközi Jogi Főosztályának vezetője. A könyv 2013-ban megvédett doktori értekezésén alapul. A mű a nemzetközi büntetőjog egy speciális területével foglalkozik, a háborús büntettek nemzeti hatóságok általi vizsgálatának lehetőségeit elemzi. Bemutatja a háborús büncselekmények mint nemzetközi jogilag üldözendő cselekmények megítélésének fejlődését, majd a nemzetközi jog nemzeti bíróságok előtti alkalmazásának akadályait vizsgálja, kifejezetten a háborús bűntettek vonatkozásában. Az utolsó fejezet pedig ezen akadályok leküzdésének lehetőségeit vázolja fel, külön kitérve a nemzetközi jogtudomány, a belső jogi jogalkotás és a nemzeti joggal foglalkozó jogtudomány megoldásaira, ezzel mintegy perspektívát adva a hazai jogalkotásnak és joggyakorlatnak is. (P. N.) 
- The Law of the European Union in Hungary

Varju Márton-Várnay Ernő (szerk.)

HVG-ORAC, Budapest, 2014

Tanulmánykötet. Terjedelem: 368. Bibliográfia: 361-368. ISBN 9789632582252

- A kötet szerkesztői a Debreceni Egyetem oktatói. A mű az Európai Unió jogának Magyarországot és a magyar jogot érintő hatásait elemzi a csatlakozást követő 10 év tapasztalatai alapján. Kitér arra, hogy az uniós jog hogyan jelenik meg egyes intézmények gyakorlatában (Alkotmánybíróság, Parlament, nemzeti bíróságok), valamint az uniós jog érvényesülését az uniós jog egyes területei (versenyjog, állami támogatások joga, az Európai Unió szerződéskötési gyakorlata) szemszögéből is vizsgálja. Erénye, hogy az egyes szerzők olyan témaköröket dolgoztak fel, melyek egyébként is a szükebb szakterületükhöz tartoznak, és így külön-külön imponáló áttekintést nyújtanak, illetve valamennyi szerző követi az első fejezetben lefektetett módszertani szempontokat. Hátránya ugyanakkor, hogy ez a megközelítés nem fedi le teljesen az uniós jog föbb területeit. (Sz. S.)

\section{JOGBÖLCSELET}

- Herbert L. A. Hart jogtudománya kritikai kontextusban

Cs. Kiss Lajos (szerk.)

(Sorozat: Bibliotheca luridica, ISSN 1586-8265; 58.)

ELTE Eötvös Kiadó, Budapest, 2014

Tanulmánykötet. Terjedelem: 992. Bibliográfia a fejezetek végén és a lábjegyzetekben. ISBN 9789632844909

- Herbert Hart az angolszász jogelmélet egyik legjelentősebb alakja. E vaskos kötet hiánypótló jelleggel egybefoglalja a Hart munkásságával kapcsolatos kutatások eredményeit, és a Hart elméletét továbbgondoló tanítványoktól, illetve Hart kritikusaitól származó tanulmányokat is közread. Az első rész Hart életútjáról tartalmaz visszaemlékezéseket, a második részben pedig megismerhetjük Hart magyarországi recepciójának főbb elemeit. A harmadik rész foglalkozik azon alapvető jogelméleti témák vizsgálatával, amelyek Hartot foglalkoztatták (például a jog fogalmának meghatározása, a szabályalapú elmélet, a nemzetközi jog elmélete, a büntetőjog elmélete, a jog és erkölcs viszonya). A negyedik részben olvashatjuk azokat a tanulmányokat, amelyekben Hart vitapartnerei fejtették ki véleményüket, illetve egyéb olyan tanulmányokat, amelyek az egy-egy témában kifejtett vitákhoz járulnak hozzá. (F. K.)

- Nyelv és jog

Dobos Csilla

Miskolci Egyetemi Kiadó, Miskolc, 2014

Monográfia. Terjedelem: 258. Bibliográfia: 245-255. ISBN 9786155216633

- A szerző a Miskolci Egyetem Bölcsészettudományi Karának nyelvész oktatója, a fordításelmélet, fordítástechnika szakértője. Kötetében a nyelvfilozófia számára igen érdekes területet vizsgál: a jog és a nyelv(filozófia) kapcsolatát. E kutatások 
hasznosak lehetnek jogászok számára is, hiszen a jogalkalmazással kapcsolatos elméletek tartalmaznak olyan álláspontokat, amelyek szerint a jogi döntések igazolásának helyes módszere a jogszabály szövegének nyelvi értelmezése. A kötet betekintést nyújt a jogi szaknyelv sajátosságainak elemzésébe, a jogi kommunikáció, a jogi fordítás, a jogi szemantika és pragmatika területeire. Az utolsó fejezet arról ad számot, hogy a jogi nyelvhasználatban a kérdéseknek milyen speciális szerepe van, mit jelentenek a jogi narratívák, valamint milyen speciális tulajdonságok jellemzik a jogi szaknyelvi stílust. (F. K.)

- „Ins Herz Geschrieben”: Die Grundlagen des freiheitlichen Rechtsstaates

El Beheiri Nadja-Erdődy János (szerk.)

(Sorozat: A Pázmány Péter Katolikus Egyetem Jog- és Államtudományi Karának Könyvei. Tanulmányok, ISSN 2061-7240; 23.)

Pázmány Press, Budapest, 2014

Tanulmánykötet. Terjedelem: 184. Bibliográfia a lábjegyzetekben. ISBN 9789633081846

- A szerkesztők a PPKE Római Jogi Tanszéke által szervezett nemzetközi konferencia angol és német nyelvű előadásainak anyagát foglalták kötetbe. A tanulmánykötet célkitǔzése, hogy a jogállam természetjogi alapjait feltárja, kiindulópontja pedig XVI. Benedek pápa 2011. szeptember 22-én a német Bundestagban tartott beszéde az emberi jogok, a jogállam természetjogi alapjairól. (A beszéd több helyen támaszkodott Wolfgang Waldstein A szívébe írva: a természetjog mint az emberi társadalom alapja címü munkájára.) $\mathrm{E}$ kötetben a szerkesztők lehetőséget láttak arra is, hogy a természetjog és az európai jogállami tradíció legfontosabb problémáit a Waldsteinnel való közös munkásságuk eredményeinek szemszögéből tárgyalják. (F. K.)

- Joghallgatók - honnan jönnek és hová tartanak?

FÓNAI Mihály

DE ÁJK-DELA Könyvkiadó, 2014

Kézikönyv. Terjedelem: 145. Bibliográfia: 125-140. ISBN 9789634737483

- A szerző szociológus, egyetemi tanár. Munkája a jogászi szakma egy sajátos dimenzióját világítja meg: a joghallgatók pályafutásával kapcsolatos empirikus kérdéseket veszi górcső alá. A jogászi szakma alakulásának, fejlődésének, társadalomban betöltött szerepének mélyebb megértéséhez és megismeréséhez járul hozzá ez a munka azzal, hogy a joghallgatók rekrutációjának, társadalmi helyzetének, pályafutásuk stációinak alapos vizsgálatát végzi el a felvételitől egészen a szakma jövőbeli lehetőségeinek feltárásáig. A kötet megvilágítja, hogy a joghallgatók milyen sajátos motivációk mellett választják a jogi egyetemet, milyen a hallgatók családi, társadalmi helyzete, milyen elvárásokat fogalmaznak meg a joghallgatók a szakmával kapcsolatban, illetve milyen véleménnyel rendelkeznek a hallgatók magáról a jogról. (F. K.) 
- A jog- és a politikai filozófia erkölcsi alapjai

FRIVALDSZKY János

(Sorozat: A Pázmány Péter Katolikus Egyetem Jog- és Államtudományi Karának Könyvei. Tanulmányok, ISSN 2061-7240; 22.)

Pázmány Press, Budapest, 2014

Monográfia. Terjedelem: 294. Bibliográfia a lábjegyzetekben. ISBN 9789633081785

- A szerző egyetemi tanár. Ebben a könyvében arra vállalkozik, hogy konkrét problémák elméleti hátterének vizsgálatával feltárja a jog- és politikai filozófia keresztény erkölcsi alapjait. Az első részben a jogfilozófia erkölcsi alapjait világítja meg néhány konkrét, a jogtudományt mindenkor foglalkoztató kérdésen keresztül (mint az emberi élet védelme, a családdal kapcsolatos elvi problémák, a gyermekek jogai, a büntetőjog, a büntetések elméleti problémái). A második fejezetben a politikai filozófia erkölcsi alapjait vizsgálja, ezen belül a közjó fogalmának elemzését végzi el, egyrészt Aquinói Szent Tamás szemszögéböl, másrészt a neokonzervatív/neoliberális korszak utáni időszakra vonatkozóan a jó kormányzás kapcsán. (F. K.)

- A jog kultúrája és etikája

KONDOROSI Ferenc-VISEGRÁdY Antal

Bíbor, Miskolc, 2014

Kézikönyv. Terjedelem: 247. Bibliográfia: 243-244. és az egyes fejezetek végén. ISBN 9789639988866

- A szerzők egyetemi tanárok. Jelen munkájuk célkitüzése, hogy az úgynevezett kulturális összehasonlítás módszerével kimutassák a hasonlóságokat és különbözőségeket a különböző kulturális keretekben kialakult jogrendszerek között, majd a vizsgálódásból levont tapasztalatokat gyakorlati jogi problémákra alkalmazzák. Ennek megfelelően a munka elemzés tárgyává teszi a legjelentősebb jogcsaládokat (római-germán, common law, szocialista vagy a vallási, tradicionális jogcsaládok) és a meghatározó jelentőségủ jogi kultúrákat (például az európai jogrendszerek sajátosságait vagy a mediterrán jogrendszerek jellegzetességeit, az iszlám jog alapjait). Az utolsó fejezetben a magyar jogfejlődés föbb irányait mutatják be a szerzők, külön kitérve az európai uniós csatlakozás hatásaira. (F. K.)

- A dialógus vonzásában - Hozzájárulás a jogászi gondolkodás természetjogi megalapozásához

PAKSY Máté

(Sorozat: A Pázmány Péter Katolikus Egyetem Jog- és Államtudományi Karának Könyvei. Tanulmányok, ISSN 2061-7240; 25.)

Pázmány Press, Budapest, 2014

Monográfia. Terjedelem: 186. Bibliográfia: 175-184. ISBN 9789633082003

- A könyv szerzője egyetemi oktató. E munka alapvető célkitűzése, hogy bemutassa a természetjogi felfogás lényegét és a jogászi gondolkodásban betöltött szerepét. A szerző álláspontja szerint a téma aktualitását mindenkor indokolják a társadalmi igazságossághoz kapcsolódó átfogó problémák, illetve a természetjog hozzájárulása a hatalom korlátozásának elvi alapjaihoz. A könyv három fejezetben tesz kísérletet a jogi gondolkodás természetjogi megalapozására: az első fejezetben 
az állam, társadalom és természetes jogok viszonyában; a második fejezetben a jogdogmatika szemszögéböl, a jogelmélet és gyakorlat kapcsolatának vizsgálatán keresztül; a harmadik fejezetben a keresztény teológia és irodalom szemszögéböl. A kötet teljes terjedelmében elérhetö a PPKE JÁK honlapján. (F. K.)

- Ratio luris: szövegek a természetjogi gondolkodás tanulmányozásához Paksy Máté-Tattay Szilárd (szerk.)

Pázmány Press, Budapest, 2014

(Sorozat: A Pázmány Péter Katolikus Egyetem Jog- és Államtudományi Karának Tankönyvei, ISSN 2062-0837)

Tanulmánykötet. Terjedelem: 258. Bibliográfia a lábjegyzetekben. ISBN 9789633082027

- A jogelmélet oktatásában segítséget nyújtó kötet a természetjogi gondolkodás legjelentősebb jogfilozófusainak (például Norberto Bobbio, John Finnis, Lon Fuller) egy-egy magyarra fordított tanulmányát tartalmazza, majd három átfogó fejezetben mutatja be, hogy a természetjog milyen szerepet játszik a jogászi gondolkodás megalapozásában. Az első rész a természetjogi gondolkodás alapjait tárgyalja, a második a természetjog jogi alapkérdések megválaszolásában betöltött szerepét vizsgálja, a harmadik pedig arra keresi a választ, hogy a természetjogi gondolkodás milyen speciális problémákat vet fel a jogászi, bírói érvelésben (például igazolhatja-e a bíró erkölcsi érvekkel a döntését, és ha igen, akkor milyen formában jelenhet meg az erkölcs a bírói indokolásokban). (F. K.)

- „Most megint Európában vagyunk...”- Szabó József emlékkönyv Révész Béla (szerk.)

(Sorozat: A Pólay Elemér Alapítvány Könyvtára, ISSN 1786-352X; 50.)

Pólay Elemér Alapítvány, Szeged, 2014

Tanulmánykötet és forráskiadás. Terjedelem: 556. Bibliográfia a lábjegyzetekben. ISBN 9786155300219

- A kötet szerzői egyetemi oktatók, elsősorban a jogbölcselet és jogtörténet művelöi. A könyv a Szegedi Tudományegyetem volt professzorának, hajdani dékánjának, az alkotmányjog és a jogbölcselet tanárának állít emléket. A benne szereplö tanulmányok a 2012-ben, Szabó József professzor halálának 20. évfordulójára rendezett konferencia és kiállítás előadásainak szerkesztett változatai, amelyek közül hat foglalkozik az életmű egyes elemeivel, további öt pedig magával az életúttal. Ez utóbbi csoport legérdekesebb eleme talán Révész Bélának a Szabó és Bibó István élettörténetének párhuzamairól írott tanulmánya. A testes könyv közel kétharmadát olyan források közlése teszi ki, amelyek a kortársak szemében valódi polihisztornak tünő professzor pályájának rajzát adják: leckekönyve, karrierjének dokumentumai, állambiztonsági iratok és levelek, elítélésének, majd 1989 utáni rehabilitációjának dokumentumai. Az értékes kötet közli a professzor közel teljes bibliográfiáját, és újraközli néhány mára alig hozzáférhető publikációját is. (B. J.) 
- Kísérlet az „új magyar jogfilozófia” megteremtésére a 20. század első felében SzABADFALVI József Gondolat, Budapest, 2014 Monográfia. Terjedelem: 297. Bibliográfia a lábjegyzetekben. ISBN 9789636935771

- A szerző egyetemi tanár. E kötetében korábbi, a 20. század első felében kibontakozó magyar jogbölcseletre vonatkozó kutatásainak eredményeit foglalja össze. Az általános, Horváth Barna álláspontján alapuló felfogás szerint az „új magyar jogfilozófia", a magyar jogbölcseleti gondolkodás új korszaka Somló Bódog munkásságával vette kezdetét. A szerző véleménye szerint azonban az "új korszak" kezdetei korábbra nyúlnak, Pulszky Ágost munkáin például már a 19. század végén érezhető az angolszász jogelméleti gondolkodás hatása, a hagyományos osztrák és német mellett. A könyv hét fejezetben, a legjelentősebb magyar jogelméleti gondolkodók (Somló Bódog, Moór Gyula, Horváth Barna) és más meghatározó szerzők munkásságának elemzése segítségével tárgyalja az „új magyar jogfilozófia" megteremtésének útját az előző századfordulótól a neokantianizmus megújításáig. (F. K.)

\section{JOGTÖRTÉNET, RÓMAI JOG}

- Az Anjouk Krakkóban - Nagy Lajos lengyelországi uralmának belpolitikai kérdései BAGI Dániel

Kronosz, Pécs, 2014

Kismonográfia. Terjedelem: 147. Bibliográfia: 123-137. ISBN 9786155339714

- A szerző történész, aki 1999-ben készítette és védte meg doktori értekezését a debreceni Kossuth Lajos Tudományegyetemen. E munka rövidített, javított változata a kötet. Tárgya szük értelemben az a 13 év (1370-1382), amely alatt az Anjou-házból származó I. (Nagy) Lajos magyar király perszonálunió formájában a lengyel trónt is birtokolta. Megírásának apropóját az adta, hogy a viszonylag teljes köztörténeti ismeretek mellett a sokkal kevésbé feldolgozott, lengyel belpolitikai vonatkozású dokumentumok világosabb képet adhatnak arról, vajon menynyire helytálló az időszakról alkotott közkeletü, alapvetően elítélő vélemény (Nagy Lajos magyar királyként csak mellékesen, mintegy számításból tartotta meg a lengyel trónt, az országot pedig csak „alapjáraton” müködtette). A szerző történész, és módszerei is történetiek (levéltári kutatás és a szakirodalom kritikai értékelése). Következtetései a jogtörténet iránt érdeklődő jogászok számára is új ismereteket nyújtanak. A könyv e-könyv formájában is hozzáférhetö. (B. J.)

- Városi szokásjog az Ars notaria alapján

BÉLI Gábor

Publikon, Pécs, 2014

Monográfia. Terjedelem: 216. Bibliográfia: 202-216. ISBN 9786155457289

- A Pécsi Tudományegyetem oktatójaként a szerző folyamatosan kitüntetett figyelmet szentel a tradicionális jog feldolgozásának és megismertetésének. Kötetével egy korábbi nagy jogtörténész generáció megkezdett munkáját folytatta, hiszen 
Uzsai János egri olvasókanonok 1351-ben lezárt formuláskönyvének, az első ismert magyar retorikai és jogi tankönyvnek és iratminta-gyüjteménynek a feldolgozására korábban Kovachich Márton György, Bónis György és részben Degré Alajos vállalkozott. Béli Gábor e munkák nyomdokain a formuláskönyv egy kis szeletét, a városi és városhoz intézett formulákat (a fennálló, de Uzsai által a kánonjog alapján kritikával tárgyalt szokásjogot) ismerteti. A hatalmas, saját kutatási bázison nyugvó kötet jelentősége - hiánypótló jellege mellett - abban áll, hogy az Árpád-kortól a 14. század közepéig terjedő időszakot, a régi, az „archaikus” városi szokásjog kiteljesedésének korát mutatja be, amely sokkal kevésbé ismert, kevésbé kutatott, mint a későbbi, városi jogcsaládok városjoga. (B. J.)

\section{- Római magánjog}

Benedek Ferenc-Pókecz Kovács Attila

(Sorozat: Institutiones Juris, ISSN 1218-9375; Dialóg Campus Tankönyvek, ISSN 1418-1274)

Második, átdolgozott kiadás. Dialóg Campus, Budapest-Pécs, 2014

Egyetemi tankönyv. Terjedelem: 372. Bibliográfia a fejezetek élén.

ISBN 9786155376368

- Benedek Ferenc, a Pécsi Tudományegyetem Állam- és Jogtudományi Karának 2007-ben elhunyt, korszakos jelentőségủ római jogász professzora az 1990-es években jelentette meg Római magánjog - Dologi és kötelmi jog címü, egyedülálló tankönyvét. Tanítványa és a katedrán utódja, Pókecz Kovács Attila e munka hagyományait követve, tisztelettel és hozzáértéssel nyúlva a nagy elöd munkájához, kisebb mértékben átdolgozta a Benedek által írott részeket, $\mathrm{s}$ hasonlóan magas színvonalon kiegészítette a tankönyvet a római magánjog kánonjának még hiányzó fejezeteivel: a római államszervezet és jogforrások történetével, a perjogot, a személy- és családjogot, valamint az öröklési jogot tárgyaló részekkel. Így didaktikai szempontból is kiváló tankönyv született. (Sz. B.)

\section{- A bíbor méltóság, a sárga árulás: szimbólumok és rituálék a jogtörténetben}

Bódiné Beliznal Kinga

Balassi, Budapest, 2014

Monográfia. Terjedelem: 315. Bibliográfia: 297-315. ISBN 9789635069347

- A szerző egyetemi oktató, e munkája a 2011 őszén megvédett doktori értekezésének átdolgozott változata. A jogi szimbólumok bemutatása, az ún. történeti ikonográfia a 20-21. század fordulóján Nyugat-Európa jogtörténészeinek egyik kedvelt kutatási területe volt. Erre vállalkozott a szerző is, az ELTE kutatócsoportjának tagjaként. A kitünően szerkesztett, színes történetekkel és képanyaggal böségesen illusztrált, élvezetes stílusban megírt könyv a színek jelentéstartalmával kezdődik. A rendi kori Európában és Magyarországon különös jelentősége volt a címerállatoknak, amelyekröl a kötet szintén bőséges információforrásul szolgál. A ruházathoz nem kevésbé füződik szimbolikus jelentés, mint a színekhez. A szerző külön fejezetet szentel a hatalmi jelvényeknek, a koronázásnak (a király, a királyné és az erdélyi fejedelem eltérő koronázási ceremóniájának), a koronázási jelvényeknek és a koronázáshoz kapcsolódó szokásoknak. A könyv követ- 
kezetes szerkesztési rendjében az általánostól a különös felé haladva a speciális eljárásokat, processzusokat is bemutatja. (B. J.)

- A Kúria és elnökei l.

Bódiné Beliznai Kinga (szerk.)

(Sorozat: Bibliotheca Curiae, ISSN 2064-9525)

HVG-ORAC, Budapest, 2014

Tanulmánykötet. Terjedelem: 234. Bibliográfia a lábjegyzetekben. ISBN 9789632582351

- Az első kötet a 2013 júniusában indult „Életutak-pályaképek” címủ konferenciasorozat előadásainak szerkesztett anyagát tartalmazza. Az első kötetben - időrendi sorrendben szerkesztve - hét volt kúriai elnök élet- és pályaképe, valamint két összefoglaló tanulmány kapott helyet (utóbbiak a Legfelsőbb Bíróság 1945-59-ig terjedő időszakának jellemzőiről, majd az 1950-es évekbeli, átpolitizált működésröl adnak rövid képet). Az elnökök közötti válogatás tekinthető önkényesnek is, hiszen a számtalan „föbíró” közül ismertebb (például Majláth György) és kevésbé ismert (például Albert herceg, Perczel Béla) személyiségek is bekerültek a nyitó kötetbe. A szerkesztés felismerhető célja - amellett, hogy a szerkesztőnek nagy szabadságot adhatott a tudat, hogy a sorozatban megjelenő további kötetek számára is hagyhat meg tartalmat - az volt, hogy az elnöki életpályákkal párhuzamosan a nemes „magyar jogászi tradíciók is közkinccsé váljanak” - fogalmazta meg a Kúria jelenlegi elnöke. (B. J.)

- A Kúria és elnökei II.

Bódiné Beliznai Kinga (szerk.)

(Sorozat: Bibliotheca Curiae, ISSN 2064-9525)

HVG-ORAC, Budapest, 2014

Tanulmánykötet. Terjedelem: 203. Bibliográfia a lábjegyzetekben.

ISBN 9789632582634

- A második kötetben mindössze két - bonyolult - pályakép kapott helyet: az erős debreceni kötődésü Juhász Andoré, valamint a Horthy-korszakban kommunistákat és nyilaskereszteseket egyaránt elítélő Töreky Gézáé. Emellett egy jelentős terjedelmü, főképp peranyagok jegyzőkönyveinek szakértő bemutatásán alapuló, hiteles tanulmány a jogászokkal (bírákkal) szemben lefolytatott koncepciós perek gyakorlatáról. A kötetet - az első kötethez hasonlóan, tudatos szerkesztési elvek folyományaként - egy rövidebb, összefoglaló jellegű tanulmány zárja a Legfelsőbb Bíróság 1953-58 közötti politikai átalakításáról. (B. J.)

- Gaius Institúciói - négy kommentár

Brósz Róbert (ford.)

Szent István Társulat, Budapest, 2014

Fordítás. Terjedelem: 191. Bibliográfia nincs. ISBN 9789632774701

- Az Eötvös Loránd Tudományegyetem európai hírủ professzora 1990-ben bocsátotta sajtó alá kézirat gyanánt Gaius, Kr. u. 2. századi berytosi (bejrúti) jogtanár jogi alapismereteket közvetítő múvét, amelyet a legújabb kutatások szerint a szer- 
ző tanári munkája során használhatott. A klasszikus római jogi források közül ez az egyetlen munka, amely szinte teljes egészében az utókorra maradt, s rendkívül nagy hatást gyakorolt az elmúlt évezredben mind a jogoktatás, mind a jogtudomány fejlődésére. A fordító bravúros munkával teszi hozzáférhetővé a magyar közönség számára is ezt a felbecsülhetetlen kultúrkincset. Jelen munka tartalmi változtatás nélkül közli az eredeti fordítást. (Sz. B.)

- Qui missilia iactant in vulgus - A nép közé történő pénzszórás a római jogban ERDŐDY János

(Sorozat: A Pázmány Péter Katolikus Egyetem Jog- és Államtudományi Karának Könyvei. Doktori értekezések, ISSN 2064-1907; 11)

Pázmány Press, Budapest, 2014 Monográfia. Terjedelem: 159. Bibliográfia: 147-159. ISBN 9789633082157

- A monográfia anyaga a Pázmány Péter Katolikus Egyetem Római Jogi Tanszéke fiatal oktatójának 2012-ben megvédett PhD-disszertációja utolsó fejezetéből nőtt ki. Míg a doktori értekezésben a szerző a iactus missilium (a magyar jogi nyelvben: pénzszórás a nép közé) esetét annak megállapítása érdekében elemezte, hogy mit tekinthettek a rómaiak jogilag pénznek, és hogyan is ment végbe a pénz tulajdonának a megszerzése, addig jelen munkája a római tulajdonszerzés dogmatikájába csak nehezen beilleszthető tényállás komplex (a társadalmi és gazdasági vonatkozásokat is mérlegelö) vizsgálatára törekszik. A szerző bátor kísérletet tesz a iactus missilium tényállásának újszerű megközelítésére, s önálló koncepcióját arra alapozza, hogy a vizsgált tulajdonkeletkeztető tényállás több különféle szerzésmód sajátosságait hordozza magában. (Sz. B.)

\section{- A római jog története és institúciói}

FöldI András-HAmZA Gábor

Tizenkilencedik, átdolgozott és bővített kiadás. Nemzedékek Tudása Tankönyvkiadó, Budapest, 2014

Egyetemi tankönyv. Terjedelem: 719. Bibliográfia: XXVI-XXXV. és a lábjegyzetekben. ISBN 978963978407

- A több egyetemen is használt, klasszikus római jogi tankönyv kismértékben átdolgozott, bővített kiadása. (Sz. B.)

- lura antiqua ac iura moderna mothodo comparativa investigata Opera selecta = Ausgewählte Schriften zur antiken Rechtsgeschichte, zur Rechtsvergleichung und zum geltenden Recht, Tom. IV

HAMZA, Gábor

Eötvös Univ. Verlag, Budapest, 2014

Tanulmánykötet. Terjedelem: 326. Bibliográfia az egyes tanulmányok végén. ISBN 9789633122112

- A szerző az ELTE egyetemi tanára, akinek életmüvéböl a negyedik gyüjteményes kötet látott napvilágot. Mint a korábbiak (az első kötet 2010-ben, a szerző 60. születésnapja tiszteletére jelent meg, a második 2011-ben - annotációja a Pro Futuro 2013/2. számában -, a harmadik pedig 2013-ban - annotációja a Pro 
Futuro 2014/2. számában), úgy ez a gyüjtemény is a professzor idegen nyelvű tanulmányainak tematikus füzére. Az aktuális kötetben német, görög és angol nyelvű történeti tanulmányokat találunk. A római jog és annak továbbhatása és a jog-összehasonlítás mellett egy kisebb dolgozat az állam és egyház(ak) viszonyát elemzi, egy másik a Harmadik Birodalom ideológiájának jogi, filozófiai és politikai gondolkodásbeli vonulatait mutatja be, az utolsó tanulmány pedig a római jog egykori professzorának, Balogh Elemérnek az életrajzát adja. Az eddigiekkel szemben e kötet sajátossága, hogy első felét egy nagy ívü tanulmány teszi ki, második részében pedig az eddigieknél több, olyan munka kapott helyet, amelynek e kötet az első közlőhelye. (B. J.)

\section{- Magyar jogtudósok - Negyedik kötet} Hamza Gábor-Siklósi Iván (szerk.)

(Sorozat: Bibliotheca Juridica Publicationes Cathedrarum, ISSN 1586-8265; LIX) ELTE Eötvös Kiadó, Budapest, 2014

Tanulmánykötet. Terjedelem: 173. Bibliográfia a lábjegyzetekben.

ISBN 9789633122143

- A hosszú szünet után megjelentetett negyedik kötetben (a sorozat 1999-es indulását követően a következő két kötet 2001-ben és 2006-ban jelent meg) a hazai jogtudomány kitünő művelőinek tollából újabb 12 jogtudós portréja áll az olvasó elött. A korábbi kötetekhez hasonló szerkezetben minden jogászportré egy életrajzi és egy pályaképi elemből tevődik össze. E kötet egyik jellegzetessége az, hogy a dualizmus nagy alakjai (Plósz Sándor, Szladits Károly, Személyi Kálmán stb.) mellett a kortársnak minősülő jogászegyéniségek tablói is megjelennek (például Benedek Ferenc, Peschka Vilmos révén), másik sajátossága pedig az, hogy több pályakép szerzője már nem él, így korábban keletkezett írásaik kerültek (vagy kiegészítve, vagy érdemi változtatás nélkül) a gyüjteménybe. A munkásság értékelő bemutatása mellett az egyes tanulmányok a jogtudósokról szóló irodalom közel teljes jegyzékét is közlik. (B. J.)

\section{- Adalékok az adózás történetéhez}

Horváth Attila-Galambos István-Marschal Adrienn (szerk.)

(Sorozat: TITE Könyvek, ISSN 2063-5753; 4.)

TITE, Budapest, 2014

Tanulmánykötet. Terjedelem: 148. Bibliográfia a lábjegyzetekben.

ISBN 9789638972736

- A szerzők tudományos kutatók. A tanulmánykötet a Pázmány Péter Katolikus Egyetem és a Történelmi Ismeretterjesztő Társulat Egyesület által 2012-ben, Az adózás története címen szervezett tudományos konferencián elhangzott előadások szerkesztett formátumú verzióit tartalmazza. A konferencia célja az adózás történetének vizsgálata volt jogtörténeti, közgazdasági és jogtudományi szempontból, így a kötetben helyet kapott valamennyi előadás e három tudományág határán mozog, s így interdiszciplinárisnak tekinthetők. A tanulmányok különböző korok, földrajzi területek vagy népcsoportok szempontjából elemzik az adózás kérdését. ( $V$. J.) 
- Magyar állam- és jogtörténet

Horváth Attila (szerk.)

NKE KTK, Budapest, 2014

Egyetemi tankönyv. Terjedelem: 664. Bibliográfia az alfejezetek végén. ISBN 9786155305900

- A mai hazai alkotmány- és jogtörténet oktatásához több korszerü tankönyv áll rendelkezésre, amelyhez a Nemzeti Közszolgálati Egyetem oktatói közössége egy monumentális terjedelmü új opusszal járult hozzá. A tankönyv a kar oktatási rendszerében domináns alkotmány- és közigazgatástörténet mellett jelentős terjedelemben - közel a tankönyv felében - jogtörténeti ismeretek átadására is vállalkozik. Tankönyvként az NKE különböző mesterképzéseiben és a doktori képzésben kívánják használni. A feldolgozás jellegzetessége, hogy az egyes témakörök nem elbeszélő részletességgel, számos adalékkal, hanem rövid, az elsajátítandó tananyagra szorítkozó, többnyire csak néhány bekezdésnyi szöveggel szerepelnek a tankönyvben, s így az valószínüleg hallgatóbarátabb, könnyebben tanulható. A tankönyv teljes szövege az interneten elektronikus formában is elérhető. ( $B$. J.)

- Tanulmányok Tárkány Szücs Ernő születésének 90. évfordulója tiszteletére Nagy Janka Teodóra (szerk.)

PTE Illyés Gyula Kar, Szekszárd, 2014

Tanulmánykötet. Terjedelem: 205. Bibliográfia a lábjegyzetekben.

ISBN 9789637305672

- A kötetben szereplő tanulmányok szerzői túlnyomó többségben egyetemi oktatók, a pécsi központtal müködő kutatócsoport tagjai. A tanulmánykötet tizenkét tanulmánya az ünnepelt emlékére 2011. október 15-én megtartott konferencia előadásainak szerkesztett változata. Az első négy tanulmány Tárkány Szücs Ernő tudományos életútjával foglalkozik, míg nyolc tanulmány az előadók tudományterületeire fókuszálva mutatja be az ünnepelt népi jogszokásaira vonatkozó kutatásainak hasznosulási lehetőségeit napjainkban. A történettudományi és a jogtörténeti kutatásokban a második világháborút követően a népi jogélet és a kultúrtörténet vizsgálata háttérbe szorult, s annak újbóli elterjedéséhez és interdiszciplináris alkalmazásához - a tanulmányok tükrében - Tárkány Szücs Ernő munkássága nagymértékben hozzájárult. (P. L.)

- A jogászi hivatásrendek története Magyarországon (1868/69-1937)

NAVRATIL Szonja

(Sorozat: ELTE Jogi Kari Tudomány, ISSN 2060-9361; 25.)

ELTE Eötvös Kiadó, Budapest, 2014

Kézikönyv. Terjedelem: 180. Bibliográfia: 165-176. ISBN 9789633122099

- A szerző egyetemi oktató, e kötete doktori disszertációján alapul. Célja, hogy hazánkban hiánypótló jelleggel feltárja a magyar bírói, ügyészi és ügyvédi hivatás társadalomtörténeti alapjait, és bemutassa, a jogászok miképp járultak hozzá Magyarországon a modern (jog)állam kialakulásához. Kötetében a jogászi hivatásokat nem intézménytörténeti szempontból, nem a jogszabályok ismertetésén keresztül, hanem a modernizációhoz, a jogállamisághoz fűződő kapcsolatukon 
keresztül vizsgálja. A vizsgálódás kiindulópontjaként a független igazságszolgáltatás megteremtésében meghatározó törvénycikkeket választotta (1868. évi LIV. törvény és 1869. évi IV. törvény), befejező évének pedig 1937-et, amely évben a független és autonóm ügyvédséget az ügyvédi rendtartási törvény tulajdonképpen felszámolta. (F. K.)

- Római jog

NótÁRI Tamás

Lectum, Szeged, 2014

Egyetemi tankönyv. Terjedelem: 364. Bibliográfia: 18-20. ISBN 9789639640474

- A Kolozsvári Sapientia Egyetem oktatója 2011-ben megjelent, több tekintetben is feltűnést keltő tankönyvének átdolgozott, néhány vonatkozásban rövidített, megváltozott címü kiadása. A forgalomban lévő római jogi tankönyvek hagyományaiból kilépve a római államszervezet fejlődésének és a római jog külső történetének, tudománytörténetének, valamint a római magánjog (eljárásjog, személyi és családi jog, dologi jog, kötelmi jog és öröklési jog) szabályainak és intézményeinek ismertetése mellett külön fejezetekben foglalkozik a római büntetőjoggal és az ún. szakrális joggal is. A korábbi változatban megtalálható bibliográfia egy része, felhasznált irodalomként az előszóban kerül megemlítésre. (Sz. B.)

\section{- A királyság és a köztársaság közjogi intézményei Rómában}

Pókecz KovÁcs Attila

(Sorozat: Institutiones Juris, ISSN 1218 9375; Dialóg Campus Tankönyvek, ISSN 1418-1274)

Dialóg Campus, Budapest-Pécs, 2014

Monográfia. Terjedelem: 162. Bibliográfia: 147-162. ISBN 9786155376405

- A Pécsi Tudományegyetem Római Jogi Tanszékének vezetője következetesen felépülő római államszervezet-történeti kutatásainak első nagyobb összefoglalását jelenti a monográfia. A szerző több, korábban megjelent tanulmányában a köztársaságkori politikai és gazdasági válságjelenségek vizsgálatától jutott el a király- és köztársaságkori közjogi intézményrendszer felvázolásához. Jelen munka három nagy fejezetben (a királyság kora, a korai köztársaság, a köztársaság válsága) nyújt átfogó képet nemcsak az intézményrendszer közismertnek vehető felépítéséröl és annak változásairól, hanem ezeket érzékletesen hozza összefüggésbe az adott korszak társadalmi és gazdasági mozzanataival. A vizsgálódás során többször hangsúlyozza a szerzö, hogy a római közpolitika jogállami keretek között müködött a köztársaság korában. (Sz. B.)

- Iratok a magyar Külügyminisztérium történetéhez 1985-1993 I.

Sáringer János (főszerk.)

Balassi Kiadó, Budapest, 2014

Forrásgyüjtemény. Terjedelem: 660. Bibliográfia nincs. ISBN 9789635069316

- A föszerkesztö történész, a nemzetközi kapcsolatok szakértője. Az iratgyüjtemény hiánypótló mü, mely tematikusan rendszerezi a feldolgozott forrásokat. Egy korábbi kiadvány az 1945 és 1950 közötti időszak külügyminisztériumi iratait dolgozta 
fel. A kötetböl nyomon követhetö a magyar Külügyminisztérium 1985-1993 közötti időszakának története, a minisztérium müködése, a külkapcsolatok alakulása. A könyv végén a korszakban született fakszimiléket és fényképeket találunk. Hasznos lehet azoknak, akik kutatómunkájuk során a külügyminisztérium müködése, illetöleg a külkapcsolatok alakulása iránt érdeklődnek. (P. N.)

- A nemlétező, érvénytelen és hatálytalan jogügyletek elméleti és dogmatikai kérdései a római jogban és a modern jogokban

SIKLÓsı Iván

(Sorozat: ELTE Jogi Kari Tudomány, ISSN 2060-9361; 23.)

ELTE Eötvös Kiadó, Budapest, 2014

Monográfia. Terjedelem: 452. Bibliográfia: 427-448. ISBN 9789633122006

- A szerző az Eötvös Loránd Tudományegyetem Római Jogi és Összehasonlító Jogtörténeti Tanszékének oktatója. A terjedelmes monográfia 2014-ben megvédett doktori disszertációjának alapos átdolgozása, melyben a szerző a magánjogi dogmatika legnehezebb kérdései közé tartozó, és a hatályos jogokban is sok bizonytalansággal kezelt jelenségkört vizsgál, figyelemre méltó forrás- és szakirodalmi bázison. A jogügyletek tekintetében a nemlétezés, az érvénytelenség és hatálytalanság fogalmainak tisztázására, elhatárolására és rendszerezésére törekszik a tudomány- és dogmatikatörténet, valamint a jog-összehasonlítás legújabb eredményeinek segítségével. A nagy ívű vizsgálódás során egyes fontos részletkérdések alapos elemzése sem marad el. (Sz. B.)

- Jogéletünk östörténete

SZÁdECZKY-KARDOSS Irma

Második kiadás. Heraldika, Budapest, 2014

Monográfia/Tanulmánykötet. Terjedelem: 340. Bibliográfia: 321-336.

ISBN 9789639204904

- A szerző a magyar őstörténet kutatója, az ELTE tiszteletbeli tanára. Könyvében a legkorábbi krónikák nyelvi és összehasonlító módszerü vizsgálata, továbbá a korabeli külföldi források utalásai alapján tesz kísérletet arra, hogy analizálja a hivatalos írásbeliség előtti ősi magyar jogélet egyes elemeit, rekonstruálja annak intézményeit. A mü alapvetően történészi szakmunka, azonban számos tanulmányában, fejezetében jogi kérdéseket boncolgat (a házasság jogi jellege, jogvesztés a sztyeppei társadalmakban, a honfoglaló törzsszövetség létrejötte, a vérszerződés és részelemei jogi jellege, mondáink jogtörténeti, jogi szimbolikai vonatkozásai stb.). Interdiszciplináris kutatásokat tartalmaz, kiemelkedően széles forrásbázisra épül, az általános történet, a jogtörténet, a népi jogélet és a jogi szimbolika iránt érdeklődők számára is tartalmaz újdonságokat. A szerző szándékai szerint egy összefoglaló munka első része, amelynek második kötete az államalapítás utáni időszak hasonló szempontú vizsgálatára fog vállalkozni. (B. J.)

- The Testimony of Medieval Canonical Collection: Texts, Manuscripts, Institutions SzUROMI Szabolcs Anzelm

(Sorozat: Bibliotheca Instituti Postgradualis luris Canonici Universitatis Catholicae 
de Petro Pázmány Nominatae, III/18, ISSN 1585-857X)

Szent István Társulat, Budapest, 2014

Monográfia. Terjedelem: 224. Bibliográfia: 199-224. ISBN 9789632774800

- A szerző a PPKE egyetemi tanára. Az angol nyelvű monográfia középkori kánonjogi forrásokat elemez, dolgoz fel. A szerző a középkori kánoni szövegekröl, kánonjogi kéziratokról és egyházi intézményekröl ad általános áttekintést, utalva egyúttal a fejlődéstörténet azon jellegzetességeire, amelyek a hatályos kánonjog szempontjából is relevánsak. A monográfia a szerző 2011 és 2013 között végzett kutatásait foglalja össze, amelyek során a Vatikáni Apostoli Könyvtárban fellelhetőeken kívül több nyugat-európai és tengerentúli egyetem könyvtárának kánonjogi forrásait is vizsgálta. (P. L.)

- VI. Szegedi Jogtörténeti Napok - Báró Eötvös József születésének 200. évfordulója alkalmából

Varga Norbert (szerk.)

SZTE ÁJK, Szeged, 2014

Tanulmánykötet. Terjedelem: 182. Bibliográfia a lábjegyzetekben.

ISBN 9789633063927

- A hatodik Szegedi Jogtörténeti Napokat az SZTE jogtörténeti tanszékei 2013 őszén rendezték meg, az egész ország jogtörténész társadalmát megmozgatva. A jelen kötet a konferencia majd 30 elöadásából tizenhárom tanulmányt foglal magában, a szerzők neve szerinti ábécérendben. A könyv részben az Eötvös tanaihoz, munkáihoz közvetlenül kapcsolódó, részben pedig Eötvös kapcsán, a kor valamely jogintézményét kifejtő tanulmányokat tartalmaz. A müvekben számos kutatási attitűd, módszertan jelenik meg: van, aki a levéltári források feltárásával és feldolgozásával készítette el tanulmányát; van, aki a jogszabályelemzésre helyezte a hangsúlyt; van, aki a fellelhető szakirodalom szintézisét adta; de a szépirodalom jogi szempontú értékelése is megjelenik egy-egy tanulmányban. A kötet kaleidoszkóp: cserepei egy komplex, nagy egésszé állnak össze, s belölük a magyar alkotmányosság meghatározó fejlődési ívét, egy állam müködését történelmi koroktól függetlenül befolyásoló kihívásokat, és azokra adott, máig adekvát válaszokat ismerhetünk meg. (B. J.)

- Ius privatum: a római magánjog története

ZLINSZKY János

Szent István Társulat, Budapest, 2014

Monográfia. Terjedelem: 217. Bibliográfia nincs. ISBN 9789632775005

- Az először 1998-ban megjelent munka formailag megújult, de tartalmában változatlan kiadása. (Sz. B.) 


\section{KÖZIGAZGATÁSI JOG}

- A „hiteles helyektöl” az elektronikus közigazgatásig - Mérföldkövek a hazai közigazgatás automatizálásának és a kormányzati számítástechnika kialakulásának történetében

Álló Géza-Molnár Szilárd (szerk.)

(Sorozat: Tanulmányok a Magyar E-közigazgatásról, ISSN 2415-9255; 1.)

Primaware, Szeged, 2014.

Szakkönyv. Terjedelem: 228. Bibliográfia az egyes fejezetek végén, valamint 219-228. ISBN 9789633063095

- A kötet szerzői és szerkesztői gyakorló szakemberek, valamint az elektronikus közigazgatás és informatika elismert kutatói, a Magyary Zoltán E-közigazgatástudományi Egyesület tagjai. Munkájuk célja a magyar közigazgatás fejlődését meghatározó csomópontoknak, valamint a számítástechnikával való kapcsolatának, továbbá a két tudományág kölcsönhatásából adódó eredményeknek a bemutatása. Bár az áttekintés a magyar (köz)igazgatás korai szakaszaira is viszszanyúlik (pl. polgári közigazgatás), a bemutatás súlypontját az 1960-as, 1970-es évek reformjai adják. A megértést fényképek, ábrák és táblázatok segítik. A közölt információk jelentős része a korabeli vezetőkkel és szemtanúkkal készült interjúkon alapul. A munkát haszonnal forgathatják a közigazgatás elektronizálása és automatizálása iránt érdeklődő elméleti és gyakorlati szakemberek egyaránt. A kiadvány, összhangban a szerzők, valamint a feldolgozott téma szellemiségével, elektronikusan is elérhetö. (B. A.)

- A közigazgatás quasi bíráskodási tevékenysége

Árva Zsuzsanna

Debreceni Egyetemi Kiadó, Debrecen, 2014

Tankönyv. Terjedelem: 225. Bibliográfia: 217-225. ISBN 9789633184479

- A szerző egyetemi oktató, aki arra vállalkozott, hogy a közigazgatás egy igen érdekes területét dolgozza fel. A közigazgatás bíráskodó, illetöleg ahhoz jellegében rendkívül hasonló tevékenységét jogdogmatikailag és történetileg is körbejárja, a kérdéskörre legjellemzöbb problémákat ismertetve. A kötet foglalkozik a közigazgatási büntetőbíráskodás alapfogalmaival és a közigazgatási büntetőjog legaktuálisabb kérdéseivel. Tekintettel arra, hogy a terület nem ragadható ki a közigazgatás egészéböl, a munka keretéül a szabálysértési jog és a helyi önkormányzati igazgatás változásai szolgálnak, valamint kiemelt figyelem jut a törvényességi felügyelet kérdéskörének bemutatására. (V. B.)

- Nagy önkormányzati kézikönyv

Bekényi József (szerk.)

Nemzeti Közszolgálati és Tankönyv Kiadó, Budapest, 2014

Kézikönyv. Terjedelem: 335. Bibliográfia a lábjegyzetekben és 331-335.

ISBN 9786155344602

- 20 évvel a rendszerváltás után Magyarország önkormányzati rendszere megújult. Ennek sarokpontjait és jellegzetességeit dolgozzák fel a szerzők, akik a témában 
jártas elméleti és gyakorlati szakemberek. A kézikönyv a hatályos rendelkezések ismertetését megelőzően érdemben foglalkozik a helyi hatalomgyakorlás hazai történetével, valamint nemzetközi modelljeivel. Az általános rendelkezések bemutatása után a kötetet az államigazgatási és önkormányzati feladatok szakigazgatási területekhez igazodó áttekintése zárja. A munkát haszonnal forgathatják a polgármesterek és önkormányzati képviselök mellett a közigazgatás más területein dolgozó szakemberek, valamint az önkormányzatok kérdései iránt érdeklődő laikusok is. (B. A.)

\section{- A magyar helyi önkormányzati rendszer átalakitása}

CsöRgITS Lajos

NKE, Budapest, 2014

Monográfia. Terjedelem: 222. Bibliográfia: 209-222. ISBN 9786155491993

- A szerző gyakorló szakember, aki munkájából kifolyólag közvetlenül megtapasztalta az önkormányzati rendszert érintő változtatásokat. Az elméleti alapok részletezése során leginkább az Alaptörvény rendelkezéseire támaszkodik. Egy nagyobb terjedelmű részben a közvetlen és közvetett demokrácia gyakorlásának szabályait mutatja be, és ennek vonatkozásában vizsgálja, hogy a politikai zsákmányelv mennyire dominál a közigazgatás helyi szintjén. Nagy hangsúlyt fektet az önkormányzatok gazdálkodásában, feladatrendszerében és finanszírozásában bekövetkezett változásokra, továbbá ezek gyakorlati hatásainak a tárgyalására. Külön részt szentel a törvényességi ellenőrzést felváltó törvényességi felügyeletnek, mely helyi szinten „örködik” a demokratikus müködés felett. Jelen kötetnek nem célja a jogi szabályozás átfogó bemutatása, leginkább arra törekszik, hogy gyakorlatias oldalról világítson rá a magyar önkormányzati rendszert érintő változásokra. (P. E.)

- Magyarország helyi önkormányzatai

Feik Csaba (szerk.)

NKE KTK, Budapest, 2014

Egyetemi jegyzet. Terjedelem: 322. Bibliográfia a lábjegyzetekben és 319-322. ISBN 9786155305313

- A szerzők egyetemi oktatók, akik munkájukkal az új önkormányzati rendszer legfontosabb intézményeit és jellegzetességeit kívánták bemutatni. A jegyzet a felsőoktatásban bevált szerkesztési logikát követve elöbb az önkormányzati autonómia alapkérdéseit taglalja, majd a nemzetközi kitekintés után rátér a magyar szabályozás ismertetésére. A kötet egyik nagy előnye, hogy a jogszabályokon túl kifejezetten utal a vonatkozó gyakorlatra, valamint a szabályok könnyebb megértése és elsajátítása érdekében - ahol erre mód van - szemléletes (folyamat-) ábrákkal és táblázatokkal egészíti ki az áttekintést. A kötet felépítése logikus, jól követhető, szövegezése letisztult. (B. A.) 
- Magyary Napok 2014: megújitás és megújulás

Horváth Attila (szerk.)

NKE, Budapest, 2014

Konferenciakiadvány. Terjedelem: 118. Bibliográfia a fejezetek végén. ISBN 9786155305801

- A szerzők egyetemi oktatók és gyakorlati szakemberek. A kiadvány két konferencia, a Tatán, 2014. június 11-én „A közigazgatás korszerüsítésének helyi és megyei tapasztalatai Komárom-Esztergom megyében" címmel, valamint a Budapesten, 2014. június 12-én „Az önkormányzati és a területi államigazgatási rendszer átalakulása" címmel rendezett konferencia szerkesztett anyaga. A munka felépítése illeszkedik a két konferencia tematikájához, tartalmában is ennek megfelelően sokszínüség jellemzi. Ismerteti a járási hivatalok munkájának tapasztalatait, a kormányablakok feladatait, de részletesen elemzi az önkormányzati feladat- és hatáskörök változását, és elemzi az államigazgatás (jelenlegi, valamint múltbeli) reformfolyamatának jellegzetességeit is. A kiadvány ajánlott nem csupán a szakterületen jártas oktatóknak és kutatóknak, de mindazoknak is, akik laikusként érdeklődnek a közelmúlt államreformjának lépései iránt. (V. B.)

\section{- Közszolgálat és fenntarthatóság}

Knoll Imre-LAKatos Péter

NKE, Budapest, 2014

Tanulmánykötet. Terjedelem: 161. Bibliográfia a fejezetek végén és a lábjegyzetekben. ISBN 9786155491641

- A kötetben megjelenő tanulmányok szerzői a fenntarthatóság témakörével foglalkozó elméleti és gyakorlati szakemberek. A tanulmánykötet nyolc fejezetre tagolódik, amely mindegyike a fenntarthatóság kérdését vizsgálja különböző szempontok alapján. Az első három fejezet elméleti vonatkozásban tárgyalja a fenntarthatóságot, annak mérési lehetőségeit és az erre szolgáló mutatószámokat, valamint a fenntarthatóság értékelésére kialakított különböző eljárásokat. Ezt követően a mű az egyes ágazatok speciális egyedi problémáit igyekszik felderíteni. Az ötödik fejezet konkrétan a fenntartható közigazgatás témakörével foglalkozik. Végezetül az utolsó három tanulmány arra tér ki, hogy az emberiség az őt körülvevő környezet fenntarthatóságát miként biztosíthatja, mindezt a katonaság és a rendörség szemszögéböl vizsgálja, valamint figyelmet szentel a katasztrófavédelem aspektusaira is. (Sz. D.)

\section{- A Magyarország helyi önkormányzatairól szóló törvény magyarázata} Nagy Marianna-Hoffman István (szerk.) Második, hatályosított kiadás. HVG-ORAC, 2014 Kommentár. Terjedelem: 574. Bibliográfia: 564-568. ISBN 9789632582276

- A kötet szerzői az ELTE jogi karának oktatói. Az önkormányzatiságban a rendszerváltás óta bekövetkező második legnagyobb átfogó reformot hozó, 2011. évi CLXXXIX. törvény (Mötv.) értelmezéséhez nyújtanak segítséget jelen kiadványnyal. Rávilágítanak arra, hogy a közel két évtizedig fennálló, és az önkormányzatiságot megszilárdító korábbi Ötv. hiányosságait hogyan próbálták kiküszöbölni 
az új szabályozással. Nemcsak egyfajta jogszabályértelmezést végeznek, hanem megpróbálják bemutatni, hogy a gyakorlatban hogyan jelenik meg ezeknek az új jogszabályi rendelkezéseknek a végrehajtása. A célközönség tág, hiszen a kötet hasznos lehet a kutatók, a felsőoktatásban tanulók és a közigazgatásban dolgozók számára is. (P. E.)

- A Kúria Önkormányzati Tanács helyi jogalkotással kapcsolatos elvárásai TILK Péter Kodifikátor Alapítvány, Pécs, 2014 Kismonográfia. Terjedelem: 111. Bibliográfia: 110. ISBN 9789638991218

- A szerző a Pécsi Tudományegyetem docense. A kötet az önkormányzatok jogalkotásának törvényességi és alkotmányossági felülvizsgálata kapcsán 2012. január 1-jén bekövetkezett változásokat tanulmányozza. A szerző a releváns jogszabályi rendelkezések bemutatását követően a Kúria Önkormányzati Tanácsa által meghozott döntéseket dolgozza fel. Elöbb az eljárási kérdések tárgyalását végzi el, majd a döntések tartalmi vizsgálatával foglalkozik, továbbá különbséget tesz a rendeletalkotásra és az egyes tárgykörök szabályozására vonatkozó megállapítások között is. Mivel a változások alapvetően az alkotmányi szabályozás módosulásából erednek, ezért nemcsak a közigazgatás területén, de alkotmányjogi szempontból is hasznos információkkal szolgáló kiadvány. (P. E.)

- Útmutató a polgármesteri és képviselői feladatok ellátásához 2014 Varga Katalin (szerk.) Pénzügyi Tájékoztató Iroda, Hagyárosbörönd, 2014 Kézikönyv. Terjedelem: 218. Bibliográfia: 211. ISBN 9789639789364

- A szerkesztő az önkormányzatok, valamint a polgármesterek feladataival már korábban is foglalkozó szakértő. Magyarországon a közigazgatás egyik alapintézménye, a helyi önkormányzatok rendszere komoly megújuláson ment keresztül a 2010-2014 közötti kormányzati ciklusban. A kiadvány célja is ezzel függ össze. Alapvetően arra irányul, hogy általános ismeretekkel segítse az önkormányzatnál dolgozók, kifejezetten a polgármesterek és képviselők munkáját az új szabályozási környezetben. Felépítésében a Magyarország helyi önkormányzatairól szóló 2011. évi CLXXXIX. törvény logikáját követi. A kötet lényegre törően foglalja össze az önkormányzati igazgatást érintő legalapvetőbb tudnivalókat. Fogalmazása letisztult, a munkát haszonnal forgathatják a területen nem jártas olvasók is. (V. B.)

\section{MUNKAJOG}

- Civil service career and HR management BoKodi Márta-HaZAFI Zoltán-Kun Attila-Petrovics Zoltán-SZAKÁcs Gábor Magyar Közlöny Lap- és Könyvkiadó, Budapest, 2014 Szakkönyv. Terjedelem: 185. Bibliográfia: 184-185. és a lábjegyzetekben. ISBN 9786155269349

- A szerző és a szerkesztők egyetemi oktatók, illetve gyakorló jogászok. A mú há- 
rom, tematikusan elkülöníthetö egységet tartalmaz. Az első tanulmány bemutatja, hogy a közigazgatási rendszer változása milyen módon és mértékben alakította át a humánerőforrás-menedzsment fejlődési irányát és a közigazgatás személyi állományát az új közszolgálati életpályamodell bevezetésével. A következő fejezet szerzői a civil és közszférában érvényesülő munkajogi szabályok közötti kapcsolatot vizsgálják, valamint a munkajogi és a közszolgálati szabályozás között meghúzódó különbség szemléltetésére törekednek. A harmadik tanulmány a közszolgálati szervezetek müködése és a humánerőforrás-menedzsment közötti kölcsönhatást tekinti át. (Sz. A.)

- Közszolgálati életpálya és emberi erőforrás gazdálkodás BoKodı Márta-HaZAFI Zoltán-Kun Attila-Petrovics Zoltán-SzAKÁcs Gábor Közigazgatási és Igazságügyi Minisztérium, Budapest, 2014 Szakkönyv. Terjedelem: 185. Bibliográfia: 184-185. és a lábjegyzetekben. ISBN 9786155269332

- A szerzők - az imént tárgyalt, angol nyelvű kiadványéval egyezően - a közszolgálati jog, a humánerőforrás-menedzsment és a munkajog területén dolgozó egyetemi oktatók és szakemberek. Három nagy témakör elemzésére vállalkoztak: a közszolgálat fejlesztésének jogi és emberi erőforrás dimenzióit, a közszolgálati jog önálló jogági fejlődését és a munkajoggal fennálló viszonyát, valamint a közszolgálati szervezetek egyes jellemzői és az emberierőforrás-gazdálkodás közti kapcsolatot tették vizsgálatuk tárgyává. Az e kérdésekkel kapcsolatos konklúzióikat a szerzők diagramokkal, táblázatokkal és statisztikákkal támasztják alá. (Gy. B.)

- Szociális jog - Társadalombiztosítási jog Gecse IstVánné-Jakab Nóra-Prugberger Tamás-Tóth Hilda-Varga Zoltán Miskolci Egyetemi Kiadó, Miskolc, 2014 Egyetemi tankönyv. Terjedelem: 246. Bibliográfia a fejezetek végén és a lábjegyzetekben. ISBN 9789639360495

- A 2013-as kiadás változatlan utánnyomása, amelynek annotációját lásd a Pro Futuro 2015/1. számában. (S. B.)

- Munkajog

Gyulavári Tamás (szerk.)

(Sorozat: ELTE Jogi Kari Tankönyvek, ISSN 2060-6494; 7.)

Harmadik, átdolgozott kiadás. ELTE Eötvös, Budapest, 2014

Tankönyv. Terjedelem: 578 . Bibliográfia a fejezetek végén és a lábjegyzetekben. ISBN 9789633122075

- A szerzők munkajogász szakemberek. Tartalmi változás, hogy a könyv tartalmazza az előző kiadás óta született kapcsolódó jogszabályok elemzését is, különös tekintettel a 2013. évi Polgári Törvénykönyv hatálybalépése miatti munkajogi módosításokra. Az első kiadás annotációját lásd a Pro Futuro 2014/1. számában, a második kiadás annotációját a Pro Futuro 2015/1. számában. (Gy. B.) 
- Le nouveau modele de carrière dans la fonction publique - les dimensions juridiques et la gestion des ressources humaines du developpement de la fonction publique

HAZAFI Zoltán

Magyar Közlöny Lap- és Könyvkiadó, Budapest, 2014

Monográfia. Terjedelem: 94. Bibliográfia a lábjegyzetekben. ISBN 9786155269370

- A szerző egyetemi oktató, gyakorló szakember. A kötet az Új közszolgálati életpálya - a közszolgálat fejlesztésének jogi és emberi erőforrás dimenziói címú munkájának francia nyelvű változata. A tanulmány szerint a közszolgálat problémáinak megközelítése túlzottan jogi szempontú, ezért a szerző egyik fő célkitüzése a jogi és az emberierőforrás-oldal átfogó vizsgálata. Előbbi esetében a differenciálódás, az egységesítés és az önálló jogági fejlődés kérdésére terjed ki az elemzés. A kutatás eredménye szerint a közszolgálat fejlődésére a szervezet- és feladatrendszer változásai, az átjárhatóság iránti igény és a munkaerőpiac gyakorol meghatározó befolyást. A szerző javaslatokat tesz a jogi szabályozás és az emberierőforrás-gazdálkodás továbbfejlesztésére. A tanulmányban több szemléletes diagram és táblázat szerepel. (P. O.)

- Munka Törvénykönyve 2014 - Az Mt. és az új Ptk. munkaviszonyra vonatkozó szabályai

HoRVÁTH István-SzLADoVNYIK Krisztina

(Sorozat: Vezinfó-tudástár, ISSN 2061-4780)

Vezinfó, Budapest, 2014

Szakkönyv. Terjedelem: 405. Bibliográfia nincs. ISBN 9786155085109

- A szerzők a munkajog területén tevékenykedő gyakorló jogászok, valamint egyetemi oktatók. A mú a Munka Törvénykönyve 2014. március 15-töl hatályos szabályainak elemzésén túl az új Polgári Törvénykönyvnek (Ptk.) a munkaviszonyban alkalmazandó rendelkezéseit is bemutatja. A szerzők kiemelten foglalkoznak a munkavállalói személyiségvédelem és a sérelemdíj kérdéskörével, illetve a munkáltatói és munkavállalói kártérítési felelősség szabályanyagával. Ezen túlmenően vizsgálódás tárgyát képezi az is, hogy mennyiben érvényesülnek az olyan klasszikus kötelmi jogi jogintézmények a gazdasági munkajog világában, mint például a tartozáselismerés vagy az előszerződés. (Sz. A.)

- Munkaügyi ellenörzés a gyakorlatban - Törvényi elöirások, jogok, kötelezettségek, felkészülési segédletek munkáltatóknak

HoRVÁth Viktória-MARECZKY Ferenc-ToRgYIK Varga Edina-CsIGI Imre-Orosz MártaVASAS János-RÉdL Petra-FEIK Csaba

Harmadik, átdolgozott kiadás. Praxis, Budapest, 2014

Szakkönyv. Szabadlapok bővíthető kötésben, kapcsolós szerkezettel. Bibliográfia nincs. ISBN 9632298551

- A szerzők az államigazgatásban dolgozó szakemberek. A munkaügyi ellenőrzés célja, hogy visszaszorítsa a jogszabályi feltételeknek meg nem felelö foglalkoztatást, illetve munkavállalást, továbbá az, hogy védje a munkavállalók és érdekképviseleti szerveik jogait. A kétkötetes kiadvány - amelybe a második kiadás óta 
bekövetkezett jogszabályi módosítások is bekerültek - segítséget nyújt a rendszer megismeréséhez, nemcsak a hazai, hanem a nemzetközi jogszabályok bemutatásán keresztül. A mü tisztázza a hatóságok szerepét és funkcióját, valamint kitér a közteherviselés feladataira is. Nagy hangsúlyt kap a kötetben a társadalmi, politikai és jogi háttér elemzése, amelyek magukban foglalják mind az elvárásokat, mind a több évre kiható stratégiákat is. Mindezeken túl részletes képet kap az olvasó a speciális ellenőrzési hatáskörökröl, valamint az intézkedési lehetőségekről egyaránt. A kötethez CD-melléklet is kapcsolódik. A második kiadás annotációját lásd a Pro Futuro 2014/1. számában. (Gy. B.)

- A munkavállalói jogalanyiság munkajogi és szociális kérdései, különös tekintettel a megváltozott munkaképességü és fogyatékos személyekre

JAKAB Nóra

Bíbor, Miskolc, 2014

Monográfia. Terjedelem: 329. Bibliográfia: 313-326. és a lábjegyzetekben. ISBN 9789639988927

- A szerző a Miskolci Egyetem oktatója. Könyvében újszerüen közelíti meg a munkajogi jogalanyiság kérdését, amely napjainkban egyre jelentősebbé váló, aktuális munkaügyi, társadalmi és szociális feszültségeket vet fel. A szerző a témához kapcsolódó munkajogi szabályok és jogintézmények széles körü ismertetése mellett felhívja az olvasó figyelmét a szociális olló és a szociális kirekesztődés jelenségeire, valamint a munkaerőpiaci előnyökből nem részesülő, fogyatékossággal élő emberek helyzetére. A mü részletesen tárgyalja továbbá a megváltozott munkaképességű munkavállalók rehabilitációját, valamint a munkavállalói jogalanyiság egyéb szociális jogi kérdéseit. A szerző az egyes témakörök vizsgálata során az uniós és nemzetközi szabályokat is elemzi. A könyv utolsó fejezetében a szerző következtetései és de lege ferenda javaslatai olvashatók. (S. B.)

- A munka dijazása

KÁRTYÁs Gábor

(Sorozat: Munkajogi Kiskönyvtár, ISSN 2063-6393; 3.)

CompLex, Budapest, 2014

Monográfia. Terjedelem: 203. Bibliográfia nincs. ISBN 9789632953748

- A szerző egyetemi oktató és gyakorló jogász. Könyvében, amely többek között a számfejtéssel és személyzeti ügyekkel foglalkozó szakembereket célozza meg, részletesen elemzi a munkabérre vonatkozó jogszabályi rendelkezéseket. A bérezés alapelveivel, az egyes díjazási jogcímekkel, a munkavégzés hiányában járó díjazással, valamint a munkabér védelmével kapcsolatos jogszabályi rendelkezéseket járja körbe, amely során a gyakorlatban felmerülő kérdésekre is igyekszik választ adni, illetve konkrét példákkal szolgálni. Segítséget nyújt ahhoz is, hogyan érdemes a munkabérrel kapcsolatos kérdéseket a munkaszerződésben vagy kollektív szerződésben szabályozni. (B. K.) 
- A munkaviszony megszünése és megszüntetése

Kulısity Mária

(Sorozat: Munkajogi Kiskönyvtár, ISSN 2063-6393; 5.)

CompLex, Budapest, 2014

Monográfia. Terjedelem: 244. Bibliográfia nincs. ISBN 9789632953922

- A szerző a Fővárosi Munkaügyi Bíróság bírája. Könyvében részletesen bemutatja a munkaviszony megszünésének és megszüntetésének eseteit, kitérve a jogellenes munkaviszony-megszüntetés jogkövetkezményeire is. A kötet a bírósági esetjogban jellemzően felmerülő jogalkalmazási kérdéseket igyekszik közérthetően körüljárni, amely így segítségül szolgálhat a mindennapi jogalkalmazás során. Gyakorlati alkalmazhatóságát elősegíti, hogy már az új polgári törvénykönyv vonatkozó szabályait is tartalmazza, valamint a releváns bírói gyakorlatot is feldolgozza. A mellékletben szereplö iratminták is hozzájárulhatnak a helyes jogalkalmazáshoz. (S. B.)

\section{- A munkajogi megfelelés ösztönzésének újszerủ jogi eszközei}

Kun Attila

(Sorozat: Károli Könyvek, ISSN 2063-3297)

KRE és L'Harmattan, Budapest, 2014

Monográfia. Terjedelem: 206. Bibliográfia: 191-206. és a lábjegyzetekben. ISBN 9789632368757

- A szerző egyetemi oktató. A könyvben három esettanulmányon keresztül vizsgálja meg, milyen újszerủ, a hagyományostól eltérő munkajogi szabályozástechnikai eszközök révén ösztönözhetők a piaci szereplök a munkajogi szabályok betartására. Ennek megfelelöen a téma elméleti megalapozásául szolgáló fejezetét követően tulajdonképpen három nagy részre tagolódik a monográfia: az első a közbeszerzés és a munkajog, a második a nem pénzügyi jelentéstétel (transzparencia) és a munkajog, a harmadik pedig az alvállalkozói láncok és a munkajog kapcsolatát teszi elemzés tárgyává, a vonatkozó uniós és nemzetközi joganyag feldolgozása révén. Minden egyes fejezet végén, külön alcím alatt vizsgálja a szerző az adott téma magyar vonatkozását is. (B. K.)

\section{- Az új Munka törvénykönyvének magyarázata}

PÁl Lajos-LöRINCZ György-KozmA Anna-PETHö Róbert

Második, hatályosított kiadás. HVG-ORAC, Budapest, 2014

Kommentár. Terjedelem: 534. Bibliográfia a lábjegyzetekben.

ISBN 9789632582290

- A szerzők ügyvédek, gyakorló jogászok. A kötet a 2012-es kiadás hatályosított és bővített változata, amely a Munka Törvénykönyve (Mt.) 2014. március 15-i állapotát tükrözi. Az első kiadáshoz képest beépítésre kerültek a kommentárba a 2012 óta bekövetkezett jogszabályi módosítások, az első jogalkalmazói tapasztalatok, a gyakorlatban felmerült értelmezési kérdések, valamint a korábban külön kötetben megjelentetett átmeneti rendelkezések. A magyarázatok az időközben hatályba lépett 2013. évi polgári törvénykönyvhöz lettek igazítva. A szöveg továbbra is az Mt. szerkezetét követi, amely feldolgozza a kapcsolódó bírói gyakorlatot, 
a változásokra tekintettel. A kötethez CD-melléklet tartozik, amely a módosításokhoz igazított, szerkeszthető munkajogi iratmintákat tartalmaz. Az első kiadás annotációját lásd a Pro Futuro 2014/1. számában. (B. K.)

- Európai és magyar összehasonlító munka- és közszolgálati jog

Prugberger Tamás-NÁdas György

CompLex, Budapest, 2014

Monográfia. Terjedelem: 744. Bibliográfia az egyes fejezetek végén. ISBN 9789632954042

- A szerzők egyetemi oktatók és gyakorló jogászok. A kötet a 2006-os kiadás hatályosított, bővített és átdolgozott változata, amely négy nagy részre tagolódik: a rendszertani kérdéseket és történelmi tapasztalatokat tartalmazó, alapozó fejezetet követően először az individuális, majd a kollektív munkajog szabályaival ismerkedhet meg az olvasó, amelyet egy magyar, egy német és egy angol nyelvü összefoglalót tartalmazó rész zár le. A szerzők részletesen ismertetik a munkajogviszony, a közszolgálati tisztviselői jogviszony, valamint a közalkalmazotti jogviszony hazai szabályain túlmenően azok európai és uniós vonatkozásait is, bedolgozva mind a hazai, mind az uniós bírósági gyakorlatot. A szerzők a kötetet Radnay József emlékének ajánlják. (B. K.)

\section{PÉNZÜGYI JOG}

- Áfalevonás és áfa-visszaigénylés

FARKAs Alexandra

(Sorozat: Kiskönyvtár az Áfáról, ISSN 2064-2237)

CompLex, Budapest, 2014

Szakkönyv. Terjedelem: 182. Bibliográfia nincs. ISBN 9789632953809

- A szerző az adóigazgatásban dolgozó szakember, könyve az általános forgalmi adóval foglalkozó „Kiskönyvtár az Áfáról” elnevezésű sorozat 3. kötete. A kiadvány az általános forgalmi adó egy részterületét, az áfalevonás és az áfa-visszaigénylés szabályait dolgozza fel két fejezetben, a 2014. év változásaival bezárólag. Az első fejezetben az áfalevonási jog alapvető szabályai kerülnek kibontásra, mint például az adólevonási jog keletkezése, általános és egyéb feltételei, a levonható és le nem vonható áfa megosztásának szabályai. A második fejezet az áfa elszámolásának és visszaigénylésének kérdéseivel foglalkozik. A könnyebb megértést az alfejezetek végén elhelyezett példák segítik. (B. P.)

- Az áfakötelezettség keletkezésének időpontja és a teljesítés helye FARKAS Alexandra

(Sorozat: Kiskönyvtár az Áfáról, ISSN 2064-2237)

CompLex, Budapest, 2014

Szakkönyv. Terjedelem: 221. Bibliográfia nincs. ISBN 9789632954219

- A szerző az adóigazgatásban dolgozó szakember. A kiadvány az általános forgalmi adóval foglalkozó „Kiskönyvtár az Áfáról” elnevezésű sorozat negyedik kötete. 
A kötetben részletes elemzés tárgyát képezi egyfelöl az adófizetési kötelezettség keletkezésének időpontjára vonatkozó szabályok, különösen a teljesítés időpontja, másfelöl a teljesítés helyének a meghatározása. Utóbbi esetében bemutatásra kerül, hogy a hozzáadott-érték alapú adó alá eső ügylet után melyik országban keletkezik áfakötelezettség, ami az uniós tagságra tekintettel is kiemelt jelentőségü kérdés. Példák színesítik a jogszabályi elemzést és teszik érthetővé a rendelkezéseket. (B. P.)

- Nagykommentár a tökepiaci törvényhez

FARKAS Péter-Szász Ágnes-TomorI Erika-Török Ilona-WeILAND Zsolt

Wolters Kluwer, Budapest, 2014

Kommentár. Terjedelem: 774. Bibliográfia nincs. ISBN 9789632954028.

- A mű a tőkepiacon dolgozó gyakorlati szakemberek által elkészített kommentár a tőkepiacról szóló, 2002 óta többször módosított 2001. évi CXX. törvényhez. A szerzők az átláthatóság és a sokoldalú felhasználhatóság érdekében a jogszabályt bekezdésről bekezdésre elemzik, amelynek köszönhetően egy terjedelmes és rendkívül részletes müvet vehet kezébe az olvasó. A kommentár a törvény hatályától kezdve tizenhárom részen és számos fejezeten keresztül járja körül a törvény rendelkezéseit. A mủ végén helyet kapnak a törvény mellékletei és a jogszabályok jegyzéke is. A könyv a gyakorlati kérdésekre, problémákra reflektál, érdemei között említhetö, hogy figyelmet szentel az uniós jogi relevanciáknak is. (L. D.)

- Vázlatos betekintés a közpénzügyi döntéshozatalba

KovÁcs Árpád

Oktatáskutató és Fejlesztő Intézet, Budapest, 2014

Monográfia. Terjedelem: 307. Bibliográfia: 287-304. ISBN 9789636827953

- A szerző egyetemi tanár, a Költségvetési Tanács elnöke. Művében kitűnően ötvözi elméleti tudását és gyakorlati ismereteit, kifejtésre kerülnek a költségvetési politikával kapcsolatos, több mint két évtizedes kutatói tapasztalatai. A nemzetközi tendenciák bemutatása mellett a hazai gyakorlat is részletes ismertetésre kerül. A mű egy kitekintéssel kezdődik, amely a közpénzügyi döntéshozatal rendszertani elhelyezését tüzi ki céljául. A szerző külön fejezetben foglalkozik továbbá a költségvetés végrehajtásával is, részletesen jellemezve a végrehajtás ellenőrzésében részt vevő intézmények müködését. A monográfia átfogó jellegét támasztja alá, hogy a közpénzügyi menedzsment kérdései mellett olyan témákkal is foglalkozik, mint a közjó vagy a versenyképesség. (Sz. A.)

\section{- Az Európai Unió által nyújtott támogatások ellenörzése}

Salamon Péter

Perfekt Gazdasági Tanácsadó, Oktató és Kiadó Zrt., Budapest, 2014

Kézikönyv. Terjedelem: 134. Bibliográfia: 132-134. ISBN 9789633948347

- A szerző egyetemi oktató. Hazánk európai uniós csatlakozása együtt járt a gazdálkodó szervezetek müködési közegének megváltozásával. Eme intézmények ellenőrzése kapcsán is érzékelhetőek voltak újítások, amire az érintettek kevéssé 
voltak felkészülve. A kiadvány a vállalkozások, illetve költségvetési szervek uniós társfinanszírozású projektjei kapcsán az Európai Unió által nyújtott támogatások ellenőrzésével foglalkozik, hogy segítse a hazai jogalkalmazók eligazodását ennek rendszerében. A szerző bemutatja az uniós támogatások ellenőrzésének jogszabályi hátterét, az alkalmazandó alapelveket, az ellenőrzés módszereit, továbbá betekintést enged az olvasók számára az ellenőrzésben részt vevő szervezetek által érzékelt legfontosabb problémákba, illetve az általuk gyüjtött tapasztalatokba. A felmerülő kérdések megértését a szerző számos példán keresztül teszi egyszerübbé. (V. J.)

\section{- Államháztartás és szakpolitikák}

Schlett András

(Sorozat: A Pázmány Péter Katolikus Egyetem Jog- és Államtudományi Karának Tankönyvei, ISSN 2062-0837)

Pázmány Press, Budapest, 2014

Tankönyv. Terjedelem: 198. Bibliográfia: 192. ISBN 9789636827953

- A szerző egyetemi oktató. A könyv elsődlegesen az államháztartási ismeretekre vonatkozó oktatási célokat szolgál. Átfogó képet ad a szakterületről, amikor az államháztartás szerepének, rendszerének bemutatása mellett foglalkozik a központi költségvetés kérdéskörével, annak bevételi oldalával, a költségvetés egyenlegével. Bemutatásra kerül továbbá a nyugdíjrendszer, az egészségügy, az oktatásfinanszírozás, valamint az elkülönített állami pénzalapok kérdése is. Aktuálpolitikai kérdésekre is választ adva a szerző külön foglalkozik az államadósság kérdésével. (Sz. A.)

\section{POLGÁRI JOG}

- A Polgári Törvénykönyv - A Ptké.-vel és az irányadó elvi iránymutatásokkal egységes szerkezetben

Aszalós Dániel (szerk.)

CompLex, Budapest, 2014

Kézikönyv. Terjedelem: 553. Bibliográfia: 505-506. ISBN 9789632953946

- A szerkesztő ügyvéd, a kiadó felelős szerkesztője. Az új Polgári Törvénykönyvröl szóló 2013. évi V. törvény 2015. március 15-én lépett hatályba. A kötet a 2014. április 15-én lezárt normaszöveget tartalmazza, jól látható módon elválasztva a nyolc könyvet. Az új Ptk. hatálybalépésével összefüggő átmeneti és felhatalmazó rendelkezésekröl szóló 2013. évi CLXXVII. törvény rendelkezéseit összekapcsolja az új Ptk. rendelkezéseivel, és így egységes szerkezetben jeleníti meg azokat. A szerző a könyvbe beillesztette az új Ptk. alkalmazása körében is megfelelően irányadó elvi iránymutatásokat, a szövegben lábjegyzetek jelölik a végrehajtási rendeleteket és a legfontosabb kapcsolódó jogszabályokat annak érdekében, hogy a könyv az új Ptk. alkalmazásához valódi iránymutatásul szolgálhasson. (F. P. P.) 
- Kötelmi jog a 2013. évi V. törvény alapján: az új Polgári törvénykönyv szövegének rövid magyarázata

BenKE József-CseHI Zoltán-Kenderes Andrea-LAndı Balázs-Nochta Tibor-SzILAS Péter

Menedzser Praxis, Budapest, 2014

Ideiglenes jegyzet. Terjedelem: 233. Bibliográfia nincs. ISBN 9789638998668

- A szerzők a Pázmány Péter Katolikus Egyetem oktatói. A magyar magánjog jelentős megújuláson megy keresztül napjainkban, ennek egyik bizonyítéka a kötelmi szabályaink nagyszabású reformja, amelyet az új Polgári Törvénykönyv tartalmaz. A jegyzet segítséget nyújt a megújult kötelmi jog világában való eligazodáshoz. Négy nagy egységből tevődik össze: az első rész a kötelmek közös szabályait, a második a szerződések általános szabályait, a harmadik rész a szerződésen kívül okozott kárért való felelősség kérdéskörét, a negyedik részben az egyéb kötelemkeletkeztető tényeket mutatja be. (Cs. E.)

\section{- Általános tanok és személyek joga}

Bíró György

Második kiadás, bővített utánnyomás. Novotni Alapítvány, Miskolc, 2014

Tankönyv. Terjedelem: 503. Bibliográfia: 496-497. ISBN 9789639360914

- A szerző a Miskolci Egyetem professzora († 2015). A könyv a 2013-as első kiadás bővített utánnyomása, mely az egyetemi hallgatók felkészülését korszerü, hatályos írott tananyaggal segíti. A tankönyv egy nyolckötetesre tervezett sorozat első darabja. A sorozat kötetei (melyek közül idáig még csak kettő készült el) a ME ÁJK-on oktatott polgári jog tantárgy oktatási témaköreihez igazodnak. Jelen kötet célja a magánjog különböző szabályanyagaiban közös alapfogalmak meghatározása. A munka a korábban külön tárgyalt Általános tanok és a Személyek joga címü kötetek összevonásával jött létre, az új Ptk. szabályai alapján. (Cs. R.)

- Elöadásvázlatok a polgári jog általános tanaiból

Boóc Ádám-SÁNDOR István

(Sorozat: Bethlen-sorozat, KRE ÁJK, ISSN 2062-2546)

Ötödik, átdolgozott és bővített kiadás. Patrocinium, Budapest, 2014

Egyetemi jegyzet. Terjedelem: 198. Bibliográfia: 191-198. és a fejezetek végén. ISBN 9786155337871

- A szerzők egyetemi oktatók. Az először 2010-ben megjelent jegyzet célja, hogy a polgári jog általános tanaiból egy átfogó, felkészülést segítő anyagot adjanak a hallgatók kezébe. A jelen kiadás a hallgatói visszajelzések alapján került kibövítésre, az egyes témakörök részletesebb kidolgozásával. Alapvetően más karok jegyzeteire és tankönyveire támaszkodik a munka, és az elméleti megközelítés mellett a gyakorlati megállapításokat is beépíti. Mindezt közérthető példákkal egészíti ki. Háttéranyagként utal a régi Ptk. szabályaira. A szerzők tervezik a munka évröl évre történő továbbfejlesztését. (T. E.) 
- A bírói hatalom kárfelelőssége

BORBÁs Beatrix

HVG-ORAC, Budapest, 2014

Monográfia. Terjedelem: 262. Bibliográfia: 255-262. ISBN 9789632582061

- A szerző egyetemi oktató és ügyvéd. A kötet abból az alaptézisből indul ki, hogy a hatalom képviseletében eljárók felelősségének politikai jelentősége és aktualitása örök. Amíg a hatalmat korlátozhatónak és számonkérhetőnek tartjuk, mindig koncepcionális kérdés lesz a felelősségre vonás módja, a felelősség fajtái és annak mértéke. A bíróság az ítélkezési tevékenységen keresztül közhatalmat gyakorol, ezért az általa okozott károkért való vagyoni helytállás konstrukcióinak szükséges a közjogi szemléletü értékelése is. A monográfia ezen ideológiai megfontolások mentén, a jogági tagolás szempontját elhagyva tárgyalja a témát, strukturált képet festve a hatályos jogi szabályozásról, elemezve a mai bírói kárfelelősségi tényállások hazai és európai joggyakorlatát, amely analízisnek aktualitását adja a magyar polgári törvénykönyv több mint egy évtizede zajló kodifikációs folyamata. (Cs. E.)

- A bizalmi vagyonkezelés

B. Szabó Gábor-lltés István-Kolozs Borbála-MenYHei Ákos-SÁndor István (Sorozat: Új magánjog sorozat, ISSN 2064-7514; 6.)

HVG-ORAC, Budapest, 2014

Kézikönyv. Terjedelem: 343. Bibliográfia: 331-339. ISBN 9789632582511

- A szerzők ügyvédek, egyetemi oktatók és PhD-hallgatók. A mü kilenc nagyobb részre tagolódik. A bizalmi vagyonkezelés valamennyi gyakorlati alkalmazási területét a külföldi gyakorlati tapasztalatok, illetve a magyar gazdasági környezet igényei és a hazai jogrendszer sajátosságainak felhasználásával mutatja be. Nem csupán ismerteti a szabályozást, hanem kritikát is megfogalmaz, valamint különbséget tesz a hasonló célt szolgáló jogi eszközök, megoldások és a bizalmi vagyonkezelés között, segítséget nyújtva ezzel az adott esetre legmegfelelőbb megoldás megtalálásához. Részletesen tárgyalja a vagyonrendelés alaki és anyagi feltételeit, a megengedett szerződési kikötéseket és a jogszerütlen módozatokat. Kitér a bizalmi vagyonkezelés adózási, számviteli, öröklési és illetékfizetési aspektusaira is. Emellett ismerteti a vagyonkezelő jogait és kötelezettségeit. A témához kapcsolódó más kérdésekkel is foglalkoznak a szerzők, mint a protektor szerepével vagy a bizalmi vagyonkezelésnek a kettős adóztatási egyezmények alapján való nemzetközi megítélésével. (T. E.)

- Ptk. fordítókulcs - Oda-vissza - A 2013. évi V. törvény és az 1959. évi IV. törvény normaszövegének összehasonlító táblázata, mindkét irányban

Gadó Gábor-Németh Anita-Sáriné Simkó Ágnes (szerk.)

Második, bővített, átdolgozott kiadás. HVG-ORAC, Budapest, 2014

Kézikönyv. Terjedelem: 673. Bibliográfia nincs. ISBN 9789632582153

- A szerkesztők gyakorló jogászok. A fordítókulcs a változások jelzésével segíti az új Polgári Törvénykönyv rendelkezéseinek megismerését és az alkalmazására történő felkészülést. Különlegessége, hogy oda-vissza használható, a 2013-as ki- 
adáshoz hasonlóan két feldolgozást tartalmaz. Mindkét összeállításban az egyes rendelkezésekhez tartozó rövid megjegyzések mutatják be a változások lényegét, vagy jelzik, ha nem változott tartalmilag a szabályozás. Az első összeállítás első hasábja a 2013. évi V. törvény (új Ptk.) szövegét tartalmazza a rendelkezések eredeti sorrendjében úgy, hogy a második hasábban az 1959. évi IV. törvény (Ptk.) rendelkezései találhatóak, de nem eredeti, hanem az új Ptk. szabályainak megfelelő rendben. Mivel a társasági törvény, a családjogi törvény és a szövetkezeti törvény szabályai bekerültek a Ptk.-ba, ezeknek a törvényeknek a megfelelö rendelkezéseit is tartalmazza a második hasáb. A másik feldolgozás a Ptk. eredeti szerkezetét követi. (Cs. E.)

- Közös jogkezelés az audiovizuális médiában

GRAD-GYENGE Anikó-SARKADY Ildikó

(Sorozat: Médiatudományi Könyvtár, ISSN 2063-5222; 10.)

NMHH Médiatanács Médiatudományi Intézete, Budapest, 2014

Tanulmány. Terjedelem: 168. Bibliográfia a lábjegyzetekben. ISBN 9786155302060

- A szerzők a médiajog művelői, egyikük egyetemi oktató, másikuk ügyvéd. A kötet a szerzői jog és a közös jogkezelés elméleti és gazdasági összefüggéseit kívánja kiemelni, tényközlésként, nem kritikaként, az NMHH támogatásával 2012-ben megjelent, A média-értéklánc szerzői jogi vonatkozásai címü kötet folytatásaként. A munka négy fejezetben tartalmaz elemzést: elsőként a közös jogkezelést általánosságban mutatja be, a történeti vonatkozásait is beleértve; ezt követően a jogintézményt a nemzetközi és az uniós jogban elhelyezve tekinti át a legfontosabb jogi dokumentumokat; a harmadik fejezet az aktuális jogkezelési paradigma kialakulásának okait tárgyalja; az utolsó egység a közös jogkezelés jövőjéröl, az európai szabályozási mechanizmusban várható irányairól értekezik. A tanulmány komplex képet nyújt a közös jogkezelés aktuális kérdéseiröl, azonban nem célja, hogy válaszokat adjon a felvetődő kérdésekre. (T. E.)

\section{- Üzleti jogi ismeretek - BA egyetemi jegyzet}

Herbst Árpád (szerk.)

Harmadik, javított kiadás. Szent István Egyetemi Kiadó, Gödöllö, 2014

Egyetemi jegyzet. Terjedelem: 165. Bibliográfia nincs. ISBN nincs.

- A szerzők a Szent István Egyetem Gazdaság- és Társadalomtudományi Kar oktatói. Bemutatják a gazdasági életben megjelenő jogi aktusokat, stabil alapismereteket kínálva a nem klasszikus jogi képzésben részt vevő hallgatók számára. Feldolgozott témaköreik a fogyasztóvédelem, az értékpapírjog, a piaci verseny, a szerződések joga és a szellemi alkotások jogvédelme. A jegyzet - vállalásához illeszkedve - a lényegre igyekszik rámutatni, alapot adva a későbbi, mélyebb jogi ismeretek elsajátításához. (Cs. E.)

- Magyar polgári jog I. - Általános rész, emberi személy, családjog, szellemi alkotások joga 
Tankönyv. Terjedelem: 376. Bibliográfia nincs. ISBN 9789632774572

- A könyv a 2013-as első kiadás változatlan utánnyomása. Annotációját lásd a Pro Futuro 2015/2. számában. (T. E.)

- Gazdasági magánjog

Károlyı Géza-Prugberger Tamás-Törö Emese-Helmeczi András

STÁTUSZ H és H KKt., Debrecen, 2014

Tankönyv. Terjedelem: 322. Bibliográfia nincs. ISBN 9789631211429

- A szerzők egyetemi oktatók. A kötet célja, hogy átfogó, rendszerezett ismereteket nyújtson a gazdasági élet alapvető jogviszonyairól, az új Polgári Törvénykönyvnek a korábbi Ptk.-hoz képest jelentősen megújult szabályozása bemutatásával. A munka kitér a gazdasági szféra alanyainak, különösen a gazdasági társaságoknak és a szövetkezeteknek a müködésére. Emellett részletesen ismerteti a természetes személyekhez kötődő vállalkozási formákat: az egyéni vállalkozóra, az egyéni cégre és a mezőgazdasági vállalkozókra vonatkozó rendelkezéseket. $A z$ anyagi jogi szabályok mellett áttekintésre kerülnek a cégjogi sajátosságok és a fizetésképtelenségi eljárások is. A kötet elsősorban gazdasági képzések hallgatóit célozza meg, de vállalkozások számára is hasznos olvasmány lehet. (T. E.)

- Polgári Jog - Az új Ptk. magyarázata

KöRÖs András-SÁRKÖZY Tamás-WELLMANN György

Második, átdolgozott, bővített kiadás. HVG-ORAC, Budapest, 2014

Kommentár. Kötetek:

1. „Bevezető és záró rendelkezések; Az ember, mint jogalany; Öröklési jog”. Terjedelem: 278. ISBN 9789632581897

2. „A jogi személy”. Terjedelem: 493. ISBN 9789632582436

3. „Családjog”. Terjedelem: 401. ISBN 9789632582443

4. „Dologi jog”. Terjedelem: 337. ISBN 9789632582450

5. „Kötelmi jog: Első és Második rész”. Terjedelem: 437. ISBN 9789632582467

6. „Kötelmi jog: Harmadik, Negyedik, Ötödik és Hatodik rész”. Terjedelem: 628. ISBN 978963 258-247 4

- A kommentár szerkesztői és szerzői kúriai bírák, kodifikátorok és jogtudósok. A hat kötetből álló kommentár az új Ptk. által újraszabályozott polgári anyagi jog törvényi rendszerét követve nyújt magyarázatot az egyes részletszabályozásokhoz, helyezi el az új jogintézményeket, és mutat rá a korábban hatályos Ptk.-ból már ismert intézmények megújult rendszerben elfoglalt helyére. Az első kiadáshoz képest átdolgozásokat és kiegészítéseket tartalmaz, a kapcsolódó törvények, az Alkotmánybíróság tevékenysége és a bírói gyakorlat alapján. Szakszerü és gyakorlatias elemzést nyújtva segíti a polgári anyagi jog új szabályozásának áttekintését és megismerését. (Cs. E.)

- Magyar polgári jog - Dologi jog

LENKOvics Barnabás

Nyolcadik, átdolgozott kiadás. Eötvös Kiadó, Budapest, 2014

Tankönyv. Terjedelem: 252. Bibliográfia: 247-252. ISBN 9789639955486 
- A kötet a korábbi, elöször 1993-ban megjelent dologi jogi tankönyveknek az új Polgári Törvénykönyv változásait figyelembe vevő, átdolgozott kiadása. A dologi jog szabályait részletesen, átfogó módon tárgyalja, tíz részben tekinti át a jelentősen átalakult dologi jogi szabályokat. A klasszikus dologi jogi rendszer szerint kitér a dologi jog fogalmára és rendszerére, a dolog fogalmára és a dolgok csoportosítására, a tulajdonjogra vonatkozó általános szabályokra, a tulajdonjogviszony tartalmára, a tulajdonjog korlátozásának eseteire, a tulajdonjog megszerzésére és megszűnésére vonatkozó rendelkezésekre, a közös tulajdonra, a tulajdonvédelemre, a korlátolt dologi jogokra és a birtok fogalmára, a birtokvédelemre és a jogalap nélküli birtoklásra. A szerző nem kívánt várni a joggyakorlat újabb irányaira, így kifejezetten csak az új kódex rendelkezéseit szándékozta újonnan beépíteni. (T. E.)

- Magyar polgári jog - Polgári jogi alapok

LeNKovics Barnabás-Keserü Barna Arnold-KöHIDI Ákos

Negyedik, átdolgozott kiadás. Eötvös József Könyvkiadó, Budapest, 2014

Tankönyv. Terjedelem: 288. Bibliográfia nincs. ISBN 9789639955561

- A szerzők egyetemi oktatók. A könyv 6 részre tagozódik: a polgári jog általános része, a személyek joga, a dologi jog, a kötelmi jog, az öröklési jog és a szellemi alkotások joga kapott helyet a kötetben. Egyszerüsített és rövidített munkáról van szó, amely szándékoltan mellőzi a társasági jog és a családjog területeinek ismertetését. Az első kiadás bővítését, hatályosítását először az EU-hoz való csatlakozásunk, majd az új Ptk. hatálybalépése, illetöleg számos új törvény megalkotása és több jogszabály módosítása indokolta. A tankönyvet a joghallgatók, valamint azon föiskolai vagy egyetemi szakok, tanfolyamok hallgatói is használhatják, akiknek kifejezetten polgári jogi alapismeretekre van szükségük. (F. P. P.)

- Polgári Jog II. - Az új Ptk. alapján

Nagy Éva-Pecze Dóra

Dialóg Campus, Budapest-Pécs, 2014

Egyetemi jegyzet. Terjedelem: 372. (I.); 472. (II.). ISBN 9786155376429 (I.); 9786155376320 (II.)

- Nagy Éva az ELTE ÁJK oktatója, Pecze Dóra gyakorló jogász. A kötetek a Jogi Szakvizsga Segédkönyvek sorozat részeként azt a célt szolgálják, hogy a hatályos jogról összefoglalt ismereteket adjon át a szakvizsgára készülö jogászoknak, igazodva az IRM Jogi Szakvizsga Bizottsága által megállapított követelményekhez. A kötetek bemutatják a témához kapcsolódó joggyakorlatot és iratmintákat is. $A z I$. kötet 18 részből áll, a teljes polgári jogi vizsgaanyag első része megtalálható benne. A II. kötet 4 fö részből áll, az első az egyes szerződésekkel, a második rész a szerződésen kívül okozott károkért való felelősséggel, a következő az egyéb kötelem-keletkeztető tényekkel foglalkozik, az utolsó fejezetben pedig az öröklési jog kapott helyet. (Cs. R.) 
- Dologi jog a 2013. évi V. törvény alapján - Az új Polgári Törvénykönyv szövegének rövid magyarázata

NAVRATYIL Zoltán

Menedzser Praxis, Budapest, 2014

Ideiglenes jegyzet. Terjedelem: 154. Bibliográfia: 152. ISBN 9789638998606

- A szerző egyetemi oktató. A kötet célja, hogy az új Polgári Törvénykönyvvel jelentősen kitágult körü és új jogi szabályozást kapott dologi jogi rendelkezéseket bemutassa és érthetővé tegye. A munka kitér a dologi jog minden nagyobb területére, de különösen nagy hangsúlyt fektet az ingatlan-nyilvántartás szabályaira: a tizenháromból négy fejezet is ezzel foglalkozik. A kötet mellékletében összegyújti azokat a legfontosabb jogszabályokat, amelyek az új Ptk. dologi jogi szabályaihoz szervesen kapcsolódnak és kiegészítik azokat. A munka tananyagként szolgál a joghallgatók számára. (T. E.)

- 2013. évi V. törvény a Polgári Törvénykönyvröl a Kúria 1/2014. PJE jogegységi határozatával felülvizsgált elvi iránymutatásokkal és új Ptk. - régi Ptk. irányú konverziós táblázattal

Orosz Árpád (szerk.)

Opten, Budapest, 2014

Kézikönyv. Terjedelem: 702. Bibliográfia: 561-566. ISBN 9786155122194

- A szerkesztő kúriai bíró, tanácselnök. A kézikönyv az új Polgári Törvénykönyvröl szóló 2013. évi V. törvény 2014 augusztusában lezárt normaszövegét tartalmazza. A gyüjtemény egyik fontos célja, hogy az 1/2014. PJE jogegységi határozatban felsorolt elvi iránymutatásokat (jogegységi határozatok, kollégiumi állásfoglalások, vélemények és elvi döntések) a Ptk. egyes rendelkezéseihez kapcsolja. Az elvi iránymutatás szövege - annak rendelkező része - rövid magyarázattal jelenik meg az egyes paragrafusok alatt. A könyv tartalmaz még egy, az új Ptk. és a régi Ptk. közötti, bekezdésszintű megfeleltetési (konverziós) táblázatot is. A kiadvány az ügyvédek mellett a közjegyzők, vállalati jogtanácsosok, bírók és ügyészek számára nyújt segítséget a jogalkalmazás mindennapjaiban. (F. P. P.)

- A Polgári Törvénykönyvröl szóló 2013. évi V. törvény és a kapcsolódó jogszabályok nagykommentárja

Osztovits András (szerk.)

Opten, Budapest, 2014

Kommentár. Kötetek:

1. „Első könyv: bevezető rendelkezések; Második könyv: az ember mint jogalany; Harmadik könyv: a jogi személy". Terjedelem: 1057. Bibliográfia nincs. ISBN 9786155122149

2. „Negyedik könyv: családjog; Ötödik könyv: dologi jog”. Terjedelem: 891. Bibliográfia nincs. ISBN 9786155122156

3. „Hatodik könyv: kötelmi jog: első rész, második rész, harmadik rész”. Terjedelem: 1334. Bibliográfia nincs. ISBN 9786155122163

4. „Hatodik könyv: kötelmi jog: negyedik rész, ötödik rész, hatodik rész; Hetedik könyv: öröklési jog; Nyolcadik könyv: záró rendelkezések". Terjedelem: 836. Bibliográfia nincs. ISBN 9786155122170 
- A szerzők a Ptk. kodifikátorai, bírák, ügyvédek, egyetemi oktatók. A munka célja, hogy segítse az új Polgári Törvénykönyv gyakorlati alkalmazását, emellett kitekintést ad a jogtörténeti előzményekre is, valamint tartalmazza a jogtudományi álláspontokat. A kommentárban magyarázat kapcsolódik valamennyi jogszabályi rendelkezéshez, a változatlan tartalmúakhoz is, külön kiemeli és ismerteti azon bírói gyakorlatot, amely nem változott az új törvény hatálybalépését követően. E munka előnye a 2013-ban megjelent kommentárokkal szemben, hogy míg azok nem számolhattak még az új Ptk. miatt módosuló több száz másik jogszabállyal, ez már több új vagy módosult jogszabály szövegét is hozzáteszi az adott rendelkezés szövegéhez. (Cs. R.)

\section{- Üzleti jog - az új Polgári Törvénykönyv után}

Pázmándi Kinga (szerk.)

Typotex, Budapest, 2014

Tankönyv. Terjedelem: 318. Bibliográfia nincs. ISBN 9789632793856

- A szerzők egyetemi oktatók. A kötet egy korábbi, 2006-os tankönyvnek az új Polgári Törvénykönyv újításai alapján továbbgondolt változata. A munka az üzleti jog két nagy területét, a társasági jogot és a kereskedelmi szerződések szabályozását tárgyalja, amit kiegészít a legfontosabb jogi alaptani ismeretekkel. A szerzők célja, hogy korszerü, európai szellemiségü tananyagot adjanak a gazdaságtudományi és mérnökképzések hallgatóinak kezébe. Ennek megfelelöen a kötet foglalkozik az Európai Unió alapkérdéseivel, iparjogvédelmi alapokkal és munkajogi ismeretekkel is. (T. E.)

- Betegjogok, orvosjogok

Petkó Mihály

Szerzői magánkiadás, Debrecen, 2014

Kézikönyv. Terjedelem: 104. Bibliográfia: 104. és a lábjegyzetekben.

ISBN 9789630893756

- A szerző egyetemi oktató. A kötet célja, hogy a hatályos szabályozás alapján a teljesség igénye nélkül, de tudományos megközelítéssel bemutassa, milyen keretek között gyakorolhatják jogaikat az egészségügyi ellátás főszereplői, a betegek és az orvosok. Vizsgálja a jelenlegi szabályozás helyénvalóságát és a témakörben kialakult bírói gyakorlatot. Kizárólag az egészségügyi törvényben foglalt jogokat érinti. Kritikai hangvételű írás, amely rámutat a jelenlegi anomáliákra, és javaslatokat tesz a jogalkotás fejlesztésére. A szerző célja, hogy a jogi oktatásban tananyagfejlesztésre felhasználhatóvá tegye munkáját. Ezen túlmenően, az egészségügy iránt érdeklődő olvasók is haszonnal forgathatják a könyvet. (T. E.)

- Terminology of Civil Law - With Optional Interactive Web-Based Content

Petz András

Anglofon Studio, Budapest, 2014

Tankönyv. Terjedelem: 208. Bibliográfia nincs. ISBN 9789630848251

- A szerző tolmács, szakfordító, az ELTE BTK Fordító- és Tolmácsképző Tanszékének megbízott oktatója. A tankönyv segítségével magabiztos tudást szerezhetünk 
a polgári jog angol nyelvű terminológiája terén. A kontinentális jog alapvető fogalmainak magyarázata, ennek keretében a polgári eljárásjog, személyi jog, dologi jog, kötelmi jog, családjog és az öröklési jog legfontosabb jogintézményeit veszi sorra. Minden fejezetben található elméleti rész, levélminta, szaknyelvi terminológia, szószedet, fogalmazói készségeket segítő anyagrész. (F. P. P.)

- A közrend fogalma a nemzetközi és belföldi kereskedelmi választottbíráskodásban Raffal Katalin

(Sorozat: A Pázmány Péter Katolikus Egyetem Jog- és Államtudományi Karának Könyvei, Doktori értekezések, ISSN 2064-1907; 10.)

Pázmány Press, Budapest, 2014

Kismonográfia. Terjedelem: 107. Bibliográfia: 103-107. és a lábjegyzetekben. ISBN 9789633081976

- A szerző a Pázmány Péter Katolikus Egyetem Jog- és Államtudományi Karának egyetemi docense. A kötet a szerző által 2008-ban megvédett, A nemzetközi magánjogi közrend rétegei - különös tekintettel a közösségi és a magyar jogra címü doktori értekezése nyomán jelent meg. A kereskedelmi választottbíráskodás egyik legfontosabb részterületével, a közrendnek a választottbíráskodásban érvényesülő szerepével foglalkozik. A szerző azt vizsgálja, hogy a közrend és a választottbíráskodás milyen vonatkozásban kapcsolódik össze, s azokat milyen nemzetközi és nemzeti jogforrások szabályozzák. A közrend fogalmának kibontása jogesetek elemzésén keresztül valósul meg, melynek során megjelenik a szerző álláspontja és véleménye is. (F. P. P.)

- Gazdasági társaságok - Cégtörvény

Sárközy Tamás (szerk.)

(Sorozat: Új magánjog sorozat, ISSN 2064-7514; 2.)

HVG-ORAC, Budapest, 2014

Kézikönyv. Terjedelem: 504. Bibliográfia nincs. ISBN 9789632582224

- A szerzők bírák, ügyvédek, jogtudósok, akik az új szabályozás előkészítésében vettek részt, illetve az új rendelkezéseket a gyakorlatban alkalmazzák. A szerzők a gazdasági társaságokra vonatkozó megújult szabályozást összefüggéseiben, elméleti igényességgel, ugyanakkor a gyakorlatban is jól alkalmazhatóan kívánják bemutatni. A munka áttekintést ad a módosult cégnyilvántartási és cégeljárási szabályokról. Megismerhetővé válik az egyes jogi személyek átalakulása, egyesülése, szétválása, a külön törvényben szereplő rendjük szerint, és ezzel párhuzamosan az új szabályozásra való átállás anyagi és eljárásjogi szabályai. A bemutatás témák szerint halad, nem a jogszabály paragrafusait követi. A mú hét nagy részre bontható, és a végén függelék található, amely a legújabb módosítások szerint tartalmazza az érintett jogszabályrészeket. (Sz. G.)

- A Bécsi Vételi Egyezmény, mint nemzetközi lingua franca - Az egységes értelmezés és alkalmazás újabb irányai és eredményei

SzABó Sarolta

(Sorozat: A Pázmány Péter Katolikus Egyetem Jog- és Államtudományi Karának 
Könyvei, Doktori Értekezések, ISSN 2064-1907; 3.)

PPKE JÁK, Budapest, 2014

Monográfia. Terjedelem: 340. Bibliográfia: 287-309. ISBN 9789633081723

- A szerző egyetemi oktató. Doktori értekezésén alapuló könyvében a Bécsi Vételi Egyezmény egyes rendelkezéseinek, összefüggéseinek jelentéstartalom-változásaira kíván rámutatni. Az egyezményt abból a szempontból közelíti meg, hogy az egy univerzális közvetítő nyelvként használható, mégpedig egyrészt közvetlenül a nemzetközi ügyletekben, másrészt közvetetten, a nemzetközi, regionális és nemzeti fejlődésben és az adásvételhez kapcsolódó jogi reformokban. A munka első egysége az egyezmény mintafunkcióját mutatja be, érintve az egységes értelmezés és alkalmazás alapjait; a második rész az egységesülő jelentéstartalmak új tendenciáit elemzi, az egyezményes koncepciók alapos tanulmányozása útján. A szerző nemcsak az egyezmény szövegét dolgozza fel, hanem a magyar belső jogot, az új Ptk.-t és az EU közös adásvételi jogra vonatkozó rendelettervezetét is összeveti az Egyezménnyel. A szerző törekvése, hogy a dolgozattal hozzájáruljon a hatékonyabb és egyértelmübb interkulturális kommunikációhoz. (T. E.)

- Civil Law Issues in Intellectual Property Rights and Consumer Protection

Szikora, Veronika-Török, Éva (szerk.)

Debrecen University Press, Debrecen, 2014

Konferenciakötet. Terjedelem: 167. Bibliográfia a lábjegyzetekben és a tanulmányok végén. ISBN 9789634737278

- A szerzők egyetemi oktatók, hallgatók, PhD-hallgatók. A kötet a DE ÁJK és a Kijevi Egyetem Jogi Karának kooperációja keretében, 2013. május 24-25-én, Debrecenben megrendezett nemzetközi konferencián elhangzott előadások írásos változatát tartalmazza. A tanulmányok érintik a szellemi tulajdon nemzetközi, magyar és ukrán jogi szabályozását, azon belül is a képzőművészet terén alkalmazandó követő jog, a hungarikumok, a kereskedelmi titokvédelem kérdéskörét, a fogyasztóvédelem terén pedig a fogyasztói hitelszerződéseket, az új Polgári Törvénykönyvnek a szellemitulajdon-védelem és a fogyasztóvédelem területét érintő újításait, így például a franchise szabályozását, illetve rámutatnak a szellemitulajdon-védelem és a fogyasztóvédelem közötti összefüggésekre is. (T. E.)

\section{- Magyar polgári jog - Öröklési jog}

VÉKÁs Lajos

Nyolcadik, átdolgozott kiadás. Eötvös, Budapest, 2014

Tankönyv. Terjedelem: 157. Bibliográfia a fejezetek végén. ISBN 9789639955578

- A szerző egyetemi oktató, az új Polgári Törvénykönyv kodifikációs folyamatának aktív alakítója. A kötet a korábbi kiadásoknak az új Polgári Törvénykönyv alapján való átdolgozása. Szerkezetében illeszkedik a korábbi kiadások tematikájához. Részletesen ismerteti az öröklési renddel, a végintézkedésen alapuló örökléssel, a törvényes örökléssel, a kötelesrésszel és az öröklés jogi hatásaival kapcsolatos jogszabályi rendelkezéseket. A munka világos szövegezésű, jól tagolt, ábrákkal segíti a jogterület áttekinthetőségét és a részletszabályok megértését. (T. E.) 
- Kommentár a Polgári Törvénykönyvhöz

Vékás Lajos-Gárdos Péter (szerk.)

Wolters Kluwer, Budapest, 2014

Kommentár. Terjedelem: 1290. (I.); 2537. (II.). ISBN 9789632954295 (I.); 978 9632954301 (II.); 9789632954288 (összkiadás)

- A szerzők egyetemi oktatók, emellett az új Ptk. megalkotásában is részt vettek. A mú az új Ptk. szövegét nemcsak a hazai, de a nemzetközi jogfejlődés vonatkozásában is vizsgálja. Az újítások mellett helyet kap a régi Ptk. joggyakorlatának értékelése is, de a mü vizsgálja a korábban kialakult gyakorlatnak az új törvény alkalmazása során is irányadó elemeit. A kommentárban feldolgozásra kerül az 1/2014. Polgári jogegységi határozat, amely az új Ptk. alapján elbírálandó ügyekben irányadó. A szerkesztők kitérnek az új Ptk. kodifikációs folyamatára, részletesen elemezve annak indokoltságát, körülményeit, az új Ptk. szerkezetét, társadalmi modelljét, nyelvezetét és a megalkotásához felhasznált külföldi példákat is. (Cs. R.)

- Kötelmek, szerződések joga az új Ptk.-ban

VEREBICS János

HVG-ORAC, Budapest, 2014

Egyetemi jegyzet. Terjedelem: 172. Bibliográfia nincs. ISBN 9789632582238

- A szerző a BMGE oktatója, a kötet az egyetem Üzleti Jogi Tanszékének szakmai mühelyében született sorozat része. Az új Polgári Törvénykönyv 6. könyvének felépítését követi, foglalkozik a szerződések közös szabályaival és az egyes szerződéstípusokkal. A munka célja, hogy bemutassa az új kódex rendelkezéseit, de a szöveg nem tartalmazza a vizsgált joganyag értelmezéseit, és a változásokat sem követi. Törekszik ugyanakkor a komplexitásra olyan szempontból, hogy a Ptk. szabályain kívül érinti a Ptké., a Ptk. módosítások szabályait, valamint a kiegészítő jellegű jogszabályozásokat. A kötet a gazdasági és műszaki szakemberek számára kíván eligazodást nyújtani. (T. E.)

\section{VEGYES TÁRGYÚ TANULMÁNYKÖTETEK}

- Változó civil világ - Kézikönyv civil szervezetek számára

BóDı György-GÉcziné Bárdosi Eszter-KaHULITs Andrea-KáKAl László-LAKRoviTs Elvira-Lele Zsófia-NAGY József-NAGY Krisztina-PotHÁtczKı Dóra-TótH Bernadett Második, bővített, átdolgozott kiadás. CompLex, Budapest, 2014 Kézikönyv. Terjedelem: 430. Bibliográfia: 423-430. ISBN 9789632954066

- A szerzők a civil szektor szakértői, akik az új Ptk. megalkotására reagáltak a kézikönyv megírásával, átfogó képet adva a civilszervezetek müködésének alapvető és problémás kérdéseiről. A kötet nemcsak jogszabályelemzéssel, hanem gyakorlati kérdésekkel, problémákkal is foglalkozik, így ajánlott nemcsak a szakemberek, hanem laikusok számára is. A mü a civilszervezetek alapításán és müködésén túl körüljárja az adózási kérdéseket, így az adókedvezményeket és a kedvezmények igénybevételéhez szükséges feltételeket is. A kézikönyv egyik 
legnagyobb pozitívuma, hogy az adott témánál megjelöli a jogforrási hátteret is, amely segít az olvasónak eligazodni a jogszabályváltozások útvesztőiben. (L. D.)

- (L)ex Cathedra et Praxis - Ünnepi kötet Lábady Tamás 70. születésnapja alkalmából

Csehi Zoltán-Koltay András-Landi Balázs-Pogácsás Anett (szerk.)

Pázmány Press, Budapest, 2014

Tanulmánykötet. Terjedelem: 634. Bibliográfia a lábjegyzetekben. ISBN 9789633082072

- A szerzők a magyar tudományos közélet képviselői az ország különböző intézményeiből. A tanulmányok átfogják a polgári jog és a kapcsolódó jogterületek mindegyikét: a tanulmányok egy része a klasszikus polgári jog témakörében, mások a kereskedelmi jog és a jogi személyek tárgykörében születtek, míg vannak, amelyek a családjog vagy az orvosi jog területét érintik. Egyes írásokat az alkotmányjog körébe soroltak a szerkesztők, emlékeztetve egyúttal arra a körülményre, hogy az ünnepelt magánjogi tudományos és oktatói munkássága mellett alkotmánybíróként is tevékenykedett. A szerzők igyekeztek megtartani az egyensúlyt az ünnepelt méltatása és a szakmai színvonal megörzése között. (T. E.)

- Ünnepi kötet dr. Bodnár László egyetemi tanár 70. születésnapjára Homoki-Nagy Mária (szerk.)

(Sorozat: Acta Universitatis Szegediensis, ISSN 0324-6523, Acta Juridica et Politica, ISSN 0563-0606; 77.)

SZTE ÁJK, Szeged, 2014

Ünnepi kötet. Terjedelem: 587. Bibliográfia a lábjegyzetekben.

ISBN 9789633063439

- A Szegedi Tudományegyetem nemzetközi jogász professzorának 70. születésnapja alkalmából megjelent kiadvány a hazai nemzetközi jogász közösség, valamint a szegedi kollégák tisztelgése az ünnepelt szakmai pályafutása előtt. A közel ötven tanulmány többsége nemzetközi jogi tárgyú, de az ünnepi kötet jogtörténeti, polgári jogi, büntetőjogi, jogelméleti és alkotmányjogi írásokat is tartalmaz, ekként kiváló „pillanatkép” is a hazai nemzetközi jogászok és szegedi vezető oktatók aktuális kutatásairól. A kötet több nemzetközi jogász szerzője igyekezett kapcsolódási pontokat keresni saját és az ünnepelt kutatásai között, ekként az írások egy része a nemzetközi szerződések jogához, illetőleg a nemzetközi jog és belső jog viszonyához kapcsolódik. (Sz. S.)

- Rendszerváltás, demokrácia és államreform az elmúlt 25 évben

Patyi András-Lapsánszky András (szerk.)

Wolters Kluwer, Budapest, 2014

Tanulmánykötet. Terjedelem: 627 . Bibliográfia a tanulmányok végén.

ISBN 9789632954080

- A kötet szerzői egyetemi oktatók. A kötet Verebélyi Imre 70. születésnapjának tiszteletére készült. A benne szereplö 45 tanulmány az államreformok kérdésköréből kiindulva az államszervezet, azon belül is elsősorban a közigazgatás intéz- 
ményrendszerének számos - az egyes szerzők tudományos munkásságához kapcsolódó - aspektusát mutatja be, így olvashatunk a rendszerváltást követő folyamatokról, azok hatásairól, illetve a várható és a megvalósult eredményeiről egyaránt. Vannak, akik Verebélyi Imre munkássága kapcsán dolgoznak fel egyegy témakört, de akad olyan is, aki a jelenben zajló folyamatokat vizsgálja, úgymint a területi államigazgatást érintő reformok, az új közszolgálati életpályamodell alakulása vagy a jogi felsőoktatás és politika kapcsolata. Nemcsak a közigazgatási jog, de a közpénzügyek és az alkotmányjog iránt érdeklődők is megtalálják a számukra érdekes témákat. A szerteágazó írásoknak köszönhetően a közigazgatás minden szintjét lefedő, átfogó, sőt a téma alkotmányjogi és nemzetközi jogi kapcsolataira is kitérő összeállításról van szó. (P. E.)

- Quaerendo et Creando - Ünnepi kötet Tattay Levente 70. születésnapja alkalmából Pogácsás Anett (szerk.)

(Sorozat: Xenia, ISSN 2061-9227)

Szent István Társulat, Budapest, 2014

Tanulmánykötet. Terjedelem: 738. Bibliográfia a lábjegyzetekben.

ISBN 9789632774862

- A szerzők többsége a PPKE oktatója, akik mellett más intézmények képviselőit is megtaláljuk az ünnepelt által müvelt szakterületről (szellemi alkotások joga). A kötetben található tanulmányok eltérő témákat érintenek, így olvashatunk a szellemi alkotások jogának szinte minden területéhez kapcsolódó írásokat: szerzői jogi, védjegyjogi, eredetvédelmi témájú dolgozatokat. Emellett találunk a magánjog általános, dogmatikai és gyakorlati kérdéseivel, sőt a magánjog és az alkotmányjog kapcsolatával, nemzetközi magánjogi problémákkal foglalkozó tanulmányokat is. A szerzők érdeklődésének megfelelően néhány környezetjogi, alkotmányjogi, jogtörténeti írás is színesíti a képet. (T. E.)

- Sale and community - Adásvétel és Közösség

Schiffner Imola-Varga Norbert (szerk.)

(Sorozat: Szegedi Jogász Doktorandusz Konferenciák, ISSN 2063-3807; IV.)

SZTE ÁJK Doktori Iskola, Szeged, 2014

Tanulmánykötet. Terjedelem: 202. Bibliográfia a lábjegyzetekben.

ISBN 9789633063286

- A kötet a 2012. november 29-én, Szegeden megrendezett doktorandusz konferencián elhangzott előadások átdolgozott és szerkesztett változatát tartalmazza. Az előadások átfogják a napjaink jogrendszerei számára jelentős kihívást jelentő, a közjog és magánjog lehetséges kapcsolódási pontjait érintő gyakorlati problémákat, szinte valamennyi jogterületet érintve. Az előadók célja az volt, hogy az adásvétel és a közösség fogalmának közös elemeit kiemeljék. A kötetben megjelenő tanulmányok a konferencián kialakult tudományos viták eredményeit is magukban foglalják. (T. E.) 
- IX. Jogász Doktoranduszok Országos Szakmai Találkozója, 2013

Törő Csaba-Cservák Csaba-Rixer Ádám-Fábián Ferenc-Miskolczi Bodnár PéterDeres Petronella-Trencsényiné Domokos Andrea (szerk.)

Károli Gáspár Református Egyetem Állam- és Jogtudományi Kar, Budapest, 2014 Konferenciakiadvány. Terjedelem: 237. Bibliográfia az egyes fejezetek végén. ISBN 9789639808560

- A kötet a 2013 novemberében, a Károli Gáspár Református Egyetemen megrendezett Jogász Doktoranduszok Országos Szakmai Konferenciájának gyűjteménye. A kötet huszonhét tanulmányt tartalmaz, nagyobbrészt magyar, kisebb részben angol nyelven. A kötetre a tematikai sokszínüség jellemző: a tudományos igénnyel készült, gazdagon lábjegyzetelt tanulmányok a jogtudomány széles spektrumát (az alkotmány- és közigazgatási jog, a büntetőjog, a civilisztika, a nemzetközi jog és a versenyjog területét is) átfogják. (D. V.)

- Az állami beavatkozás joga és hatékonysága

VÉRTESY László

NKE KTK, Budapest, 2014

Monográfia. Terjedelem: 194. Bibliográfia: 183-193. ISBN 9786155305337

- A szerző egyetemi oktató. A könyv egy minden korban visszatérő kérdést vesz górcső alá, több tudományterület szempontjai alapján. A szerző előre jelzi, hogy az egyes fejezetekben tárgyaltak szorosan összefüggő témakörök, a „megoldás” ezek komplexitásában keresendő. Így államelméleti szempontból taglalja „a jó kormányzás" teoretikus téziseit, majd összeveti a modern kor két alapvető közigazgatási technikáját, az NPM- és az NWS-modellt. A jogi aspektus esetén a kormányzás jogalkotásban játszott szerepére fókuszál, s különböző modelleket prezentál azok tervezésére (SWOT, McKinsey-mátrix stb.) és megvalósítására. Végül részletezi, hogy a beavatkozás hatékonysága többféle „részindikátorral” és elméleti alapossággal kidolgozott módszerrel mérhető, melyeket be is mutat. Zárógondolatai felhívják a figyelmet a visszásságokra. (H. K.) 